\begin{tabular}{|c|c|c|}
\hline $\begin{array}{l}\text { 2. To: (Receiving Organization) } \\
\text { Distribution }\end{array}$ & $\begin{array}{l}\text { 3. From: (originating Organization) } \\
\text { Regulatory Program }\end{array}$ & $\begin{array}{r}\text { 4. Related EDT No.: } \\
\text { N/A }\end{array}$ \\
\hline $\begin{array}{l}\text { 5. Proj./Prog./Dept./Div.: } \\
\text { Spent Nuclear Fuel Project }\end{array}$ & $\begin{array}{l}\text { 6. Cog. Engr.: } \\
\text { D. A. Reny }\end{array}$ & $\begin{array}{l}\text { 7. Purchase arder No.: } \\
\qquad \mathrm{N} / \mathrm{A}\end{array}$ \\
\hline \multirow{2}{*}{\multicolumn{2}{|c|}{$\begin{array}{l}\text { 8. Originator Remarks: } \\
\text { This document is being distributed for Final Approval }\end{array}$}} & $\begin{array}{c}\text { 9. Equip./Component No.: } \\
\text { N/A }\end{array}$ \\
\hline & & $\begin{array}{c}\text { 10. System/Bldg./Facility: } \\
\text { N/A }\end{array}$ \\
\hline \multirow{3}{*}{\multicolumn{2}{|c|}{ 11. Receiver Remarks: }} & $\begin{array}{c}\text { 12. Major Assm. DNg. No.: } \\
\text { N/A }\end{array}$ \\
\hline & & $\begin{array}{l}\text { 13. Permit/Permit Application No.: } \\
\text { N/A }\end{array}$ \\
\hline & & 14. Required Response Date: \\
\hline
\end{tabular}

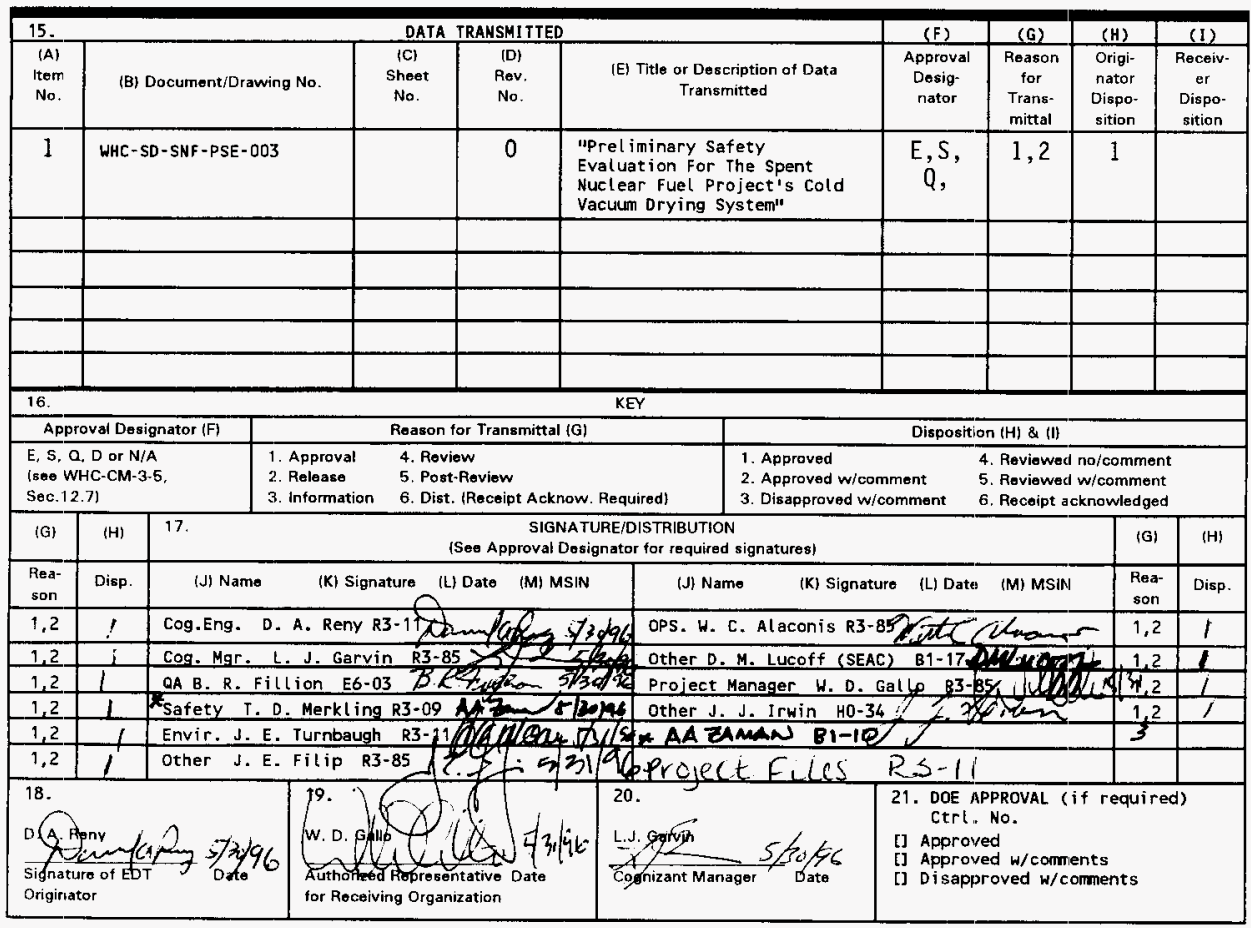




\title{
Preliminary Safety Evaluation For The Spent Nuclear Fuel Project's Cold Vacuum Drying System
}

\author{
L. J. Garvin
}

Westinghouse Hanford Company, Richland, WA 99352

U.S. Department of Energy Contract DE-AC06-87RL10930

\begin{tabular}{|c|c|c|}
\hline $\begin{array}{l}\text { EDT/ECN: } \\
\text { Org Code: } \\
\text { B\&R Code: }\end{array}$ & $\begin{array}{r}607673 \\
20000\end{array}$ & $\begin{array}{l}\text { UC: } \\
\text { Charge Code: LH063 } \\
\text { Total Pages: } 106\end{array}$ \\
\hline
\end{tabular}

Key Words: Cold Vacuum Drying System, Preliminary Hazard Analysis,

Abstract: This preliminary safety evaluation (PSE) considers only the Cold Vacuum Drying System (CVDS) facility and its mission as it relates to the integrated process strategy (WHC 1995). The purpose of thie PSE is to identify those CVDS design functions that may require safety-calss and safety-significant accident prevention and mitigation features.

TRADEMARK DISCLAIMER. Reference herein to any specific commercial product, process, or service by trade name, trademark, manufacturer, or otherwise, does not necessarily constitute or imply its endorsement, recommendation, or favoring by the United States Government or any agency thereof or its contractors or subcontractors.

Printed in the United States of America. To obtain copies of this document, contact: WHC/BCS Document Control Services, P.D. Box 1970, Mailstop H6-08, Richland WA 99352, Phone (509) 372-2420;

Fax (509) 376-4989.
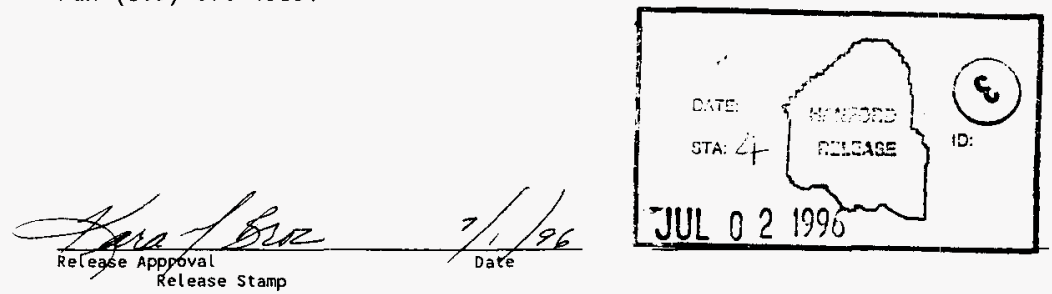

Approved for Public Release 
PRELIMINARY SAFETY EVALUATION FOR THE SPENT NUCLEAR FUEL PROJECT'S COLD VACUUM DRYING SYSTEM

May 1996

Prepared for the U.S. Department of Energy Office of Environmental Restoration and Waste Managment

Westinghouse Hanford Company

P. O. Box 1970

Richland, Washington 99352 
PRELIMINARY SAFETY EVALUATION FOR THE SPENT NUCLEAR FUEL PROJECT'S COLD VACUUM DRYING SYSTEM

WHC-SD-SNF-PSE-003

Revision 0

May 1996 
WHC-SD-SNF-PSE-003 REV 0

This page intentionally left blank. 
WHC-SD-SNF-PSE-003 REV 0

\section{CONTENTS}

1.0 INTRODUCTION AND SUMMARY .................... $1-1$

1.1 BACKGROUND . . . . . . . . . . . ............ . . . . . . . . . .

1.2 PURPOSE . . . . . . . . . . . . . . . . . . . . . . $1-2$

1.3 SUMMARY ......................... . . . . . .

2.0 DESIGN CRITERIA ...................... . . . . . . . . .

2.1 FACILITY AND PROCESS DESCRIPTIONS . . . . . . . . . . . . $2-1$

2.1.1 Facility Description . . . . . . . . . . . . . . . 2-1

2.1.2 Process Description .............. . 2-9

2.2 DESIGN REQUIREMENTS . . . . . . . . . . . . . . . . . . . 2-10

2.2.1 Safety Classification Criteria.......... . 2-10

2.2.2 Natural Phenomena Hazards . . . . . . . . . . . . . 2-11

2.2.3 Decontamination and Decommissioning . . . . . . . 2-14

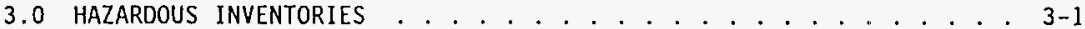

3.1 RADIOACTIVE INVENTORY ....................... . . . . . . . .

3.2 HAZARDOUS MATERIAL INVENTORY . . . . . . . . . . . . . . 3-1

4.0 ACCIDENT EVALUATION . . . . . . . . . . . . . . . . . . . . 4-1

4.1 PRELIMINARY HAZARD ANALYSIS ................. . . . . . 4-1

4.2 ACCIDENT ANALYSIS METHODOLOGY . . . . . . . . . . . . . 4-11

4.2.1 Source Term Development . . . . . . . . . . . . . . 4-11

4.2.2 Dose Calculation ................. . 4-13

4.3 ACCIDENT ANALYSIS . . . . . . . . . . . . . . . 4-15

4.3.1 Fire.................... . . 4-15

4.3.2 Flammable Gas Ignition . . . . . . . . . . . . . . 4-16

4.3.3 Multicanister Overpack Overpressurization . . . . . . 4-23

4.3.4 Multicanister Overpack Mechanical Damage . . . . . . . . 4-25

4.3.5 Fuel Ignition . . . . . . . . . . . . . . . . 4-28

4.3.6 Liquid Releases . . . . . . . . . . . . . . . . 4-31

4.4 ACCIDENT ANALYSIS SUMMARY . . . . . . . . . . . . . . . 4-36

4.5 CONSTRUCTION HAZARDS ..................... 4-36

5.0 CONSTRUCTION RISKS . . . . . . . . . . . . . . . . . . 5-1

5.1 CONSTRUCTION AND MODIFICATION ACTIVITIES ......... . . . . 5 - .

5.2 WASTE MINIMIZATION AND HAZARDOUS MATERIAL

USAGE DURING CONSTRUCTION ......................... 5-

6.0 SAFETY DOCUMENTATION . . . . . . . . . . . . . . . . . . 6-1

6.1 DESIGN DOCUMENTATION . . . . . . . . . . . . . . . . . . . 6-1

6.1.1 Multicanister Overpack Topical Report . . . . . . . . 5-1

6.1.2 Criticality Safety Evaluation Report . . . . . . . . 6-1

6.1.3 Safety Analysis Report ................ 6-1

6.1.4 Technical Safety Requirements . . . . . . . . . 6-2

6.1 .5 Fire Hazard Analysis... . . . . . . . . . . . . . 6-2

6.2 QUALITY ASSURANCE DOCUMENTATION . . . . . . . . . . . . . $6-2$

6.3 SAFEGUARDS AND SECURITY DOCUMENTATION . . . . . . . . . . . . $6-3$ 


\section{CONTENTS (Continued)}

7.0 PROJECT INTERFACES ......................... . . . . . . . . . . . .

7.1 FACILITY AND DESIGN INTERFACES . . . . . . . . . . . . . . . . . $7-1$

7.2 ACTIVITY INTERFACES . . . . . . . . . . . . . . . . . . 7-1

7.2.1 U.S. Department of Energy Spent Nuclear

Fuel Project Division ............... . 7-1

7.2.2 Organizational Support . . . . . . . . . . . . $7-2$

7.2.3 Architect-Engineer . . . . . . . . . . . . . 7-2

7.2.4 Construction Manager . . . . . . . . . . . . . . . 7-3

7.2.5 Facility Safety Evaluation Reviews . . . . . . . . . 7-3

8.0 ITEMS REQUIRING FURTHER RESOLUTION . . . . . . . . . . . 8-1

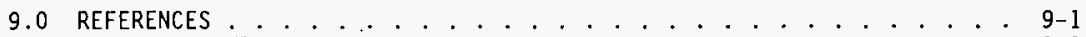

9.1 ACTS AND CODES ......................... . . . . . . . .

9.2 DOCUMENTS . . . . . . . . . . . . . . . . . . . . 9-1

9.3 U.S. DEPARTMENT OF ENERGY ORDERS AND STANDARDS . . . . . . . $9-3$

9.4 CONTROLLED MANUALS . . . . . . . . . . . . . . . 9-4

APPENDIX

A PRELIMINARY HAZARD ANALYSIS . . . . . . . . . . . . . . . . A-1 


\section{WHC-SD-SNF-PSE-003 REV 0}

\section{LIST OF FIGURES}

2-1 Location of the Cold Vacuum Drying System . . . . . . . . . . . 2-2

2-2 Site Plan for the Cold Vacuum Drying System Facility. . . . . . . . 2-3

2-3 Architectural Perspective of the Cold Vacuum Drying System Building as Seen from the West................ . 2-4

2-4 Architectural Perspective of the Cold Vacuum Drying System Building as Seen from the East.................. 2-5

2-5 Architectural Elevations of the Cold Vacuum Drying System Building . . . . . . . . . . . . . 2-6

2-6 Cold Vacuum Drying System Building Floor Plan ........... 2-7

2-7 Flow Diagram of Cold Vacuum Drying Process............ 2-8 


\section{LIST OF TABLES}

2-1 Preliminary List of Safety-Class Structures, Systems, and Components Required for the Cold Vacuum Drying System . . . . . . . 2-12

3-1 Radiological Analysis of K Basin Fuel . . . . . . . . . . . 3-2

4-1 Consequence Categories . . . . . . . . . . . . . . . 4-2

4-2 Frequency Categories . . . . . . . . . . . . . . . . . 4-2

4-3 Radiological Analysis of K Basins Fuel - Inhaled Doses . . . . . 4-12

4-4 Atmospheric Dispersion Coefficients Used in Accident Analyses for the Cold Vacuum Drying System Facility . . . . . . . . 4-14

4-5 Gas Composition and Quantities in Multicanister Overpack. Before Deflagration.............. . . . 4-17

4-6 Gas Composition and Quantities after Deflagration . . . . . . 4-18

4-7 Calculated Dose Consequences for Multicanister Overpack Flammable Gas Ignition ..................... 4-23

4-8 Calculated Dose Consequences for Multicanister Overpack

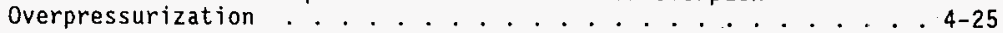

4-9 Calculated Dose Consequences for Multicanister Overpack Mechanical Damage................. . . 4-28

4-10 Summary of Calculated Dose Consequences for Fuel Ignition . . . . . 4-31

4-11 Calculated Dose Consequences for Liquid Releases . . . . . . . 4-36 


\section{WHC-SD-SNF-PSE-003 REV 0}

\section{LIST OF TERMS}

$\begin{array}{ll}\text { ARF } & \text { airborne release fraction } \\ \text { CSB } & \text { Canister Storage Building } \\ \text { CVDS } & \text { Cold Vacuum Drying System } \\ \text { DOE } & \text { U.S. Department of Energy } \\ \text { DOE-RL } & \text { U.S. Department of Energy, Richland Operations office } \\ \text { EDE } & \text { effective dose equivalent } \\ \text { FSAR } & \text { final safety analysis report } \\ \text { MCO } & \text { multicanister overpack } \\ \text { NPH } & \text { natural phenomena hazard } \\ \text { NRC } & \text { U.S. Nuclear Regulatory Commission } \\ \text { PHA } & \text { prel iminary hazard analysis } \\ \text { PSE } & \text { preliminary safety evaluation } \\ \text { RF } & \text { respirable fraction } \\ \text { SNF } & \text { Spent nuclear fuel } \\ \text { WHC } & \text { Hestinghouse Hanford Company }\end{array}$


WHC-SD-SNF-PSE-003 REV 0

This page intentionally left blank. 
WHC-SD-SNF-PSE-003 REV 0

\section{SPENT NUCLEAR FUEL PROJECT COLD VACUUM DRYING SYSTEM PRELIMINARY SAFETY EVALUATION}

\subsection{INTRODUCTION AND SUMMARY}

\subsection{BACKGROUND}

The U.S. Department of Energy (DOE) established the $K$ Basins Spent Nuclear Fuel (SNF) Project to address safety and environmenta? concerns associated with deteriorating SNF currently stored under water in the Hanford Site's K Basins. WHC-EP-0830, Hanford Spent Nuclear Fuel Recommended Path Forward (Fulton 1994), and its subsequent update, WHC-SD-SNF-SP-005, Hanford Spent Nuclear Fuel Project Integrated Process Strategy for $X$ Basins spent Nuclear Fuel (WHC 1995), recommend a series of projects to construct and operate systems and facilities to manage the safe removal and storage of $\mathrm{K}$ Basins fuel. The recommendations in WHC-SD-SNF-SP-005 (WHC 1995) include the following process steps:

- Prepare the fuel at the $K$ Basins and package it in multicanister overpacks (MCOs)

- Remove free water at the Cold Vacuum Drying System (CVDS) facility located near the $\mathrm{K}$ Basins

- Ship fuel from the CVDS facility to the Canister Storage Building (CSB) in the 200 East Area of the Hanford Site

- Provide temporary staging of MCOs in the CSB

- Remove the remaining absorbed water from the MCOs at the Hot Conditioning Annex collocated at the CSB

- Provide interim dry storage of the MCOS in the CSB until a suitable long-term repository is established.

In Memorandum EM-36-3.1.6.7, Concurrence with K-Basins Spent Nuclear Fuel Project Policy on Nuclear Safety Requirements (Grumbly 1995), the DOE established the requirement for new SNF Project facilities to achieve nuclear safety equivalency to comparable U.S. Nuclear Regulatory Commission (NRC)-licensed facilities. Nuclear safety equivalency was defined as conformance with

- Technical requirements that meet the nuclear safety objectives of NRC regulations for fuel treatment and storage facilities, including requirements regarding radiation exposure 1 imits, safety analysis, design and construction

- Administrative requirements that meet the objectives of the major elements of the NRC licensing process, including formally documented design and safety analyses, independent technical review, and opportunity for public involvement. 
Technical requirements, in context of the Policy (Grumbly 1995) and as interpreted by the Integrated Process Strategy Regulatory Requirements Team (see Section 7.2.5.1), are the design and construction measures (as opposed to preoperational or operational measures) that are mandated by the NRC

regulations. In addition, the Policy specifically excludes those requirements that address only environmental, Occupational Safety and Health Administration, chemical accident safety, and other non-nuclear safety issues (Grumbly 1995).

\subsection{PURPOSE}

This preliminary safety evaluation (PSE) considers only the CVDS facility and its mission as it relates to the integrated process strategy (WHC 1995). The purpose of this PSE is to identify those CVDS design functions that may require safety-class and safety-significant accident prevention and mitigation features. DOE Order 6430.1A, General Design Criteria, identifies the need to define safety-class items; WHC-CM-4-46, Nonreactor Facility Safety Analysis Manual, Section 9.0, "Safety Structures, Systems, and Components," defines a process by which to identify safety-class items.

The design philosophy for safety-class and safety-significant items is to establish mitigative and/or preventive design features considering the operating philosophy, cost-effectiveness of design alternatives, and schedule constraints. The general philosophy will be to confine releases with safety design features as close to the release source as possible.

\subsection{SUMMARY}

Using DOE and nuclear safety equivalency requirements has led to the identification of safety-class structures, systems, and components (SSCS). The preliminary list of these SSCs can be found in Chapter 2.0. These SSCs fulfill the required safety functions of a hazard category 2 facility by preventing the unacceptable dose consequences identified in the accident analysis in Chapter 4.0. The CVDS has been assigned a hazard category of 2 based on the radioactive materials inventory at risk for release, unmitigated by any safety features (Bradshaw 1996). Hazard category 2 indicates that the CVDS facility has the potential for "significant onsite consequences" as defined in DOE Order 5480.23, Nuclear Safety Analysis Reports.

The protection of safety-class SSCs from physical interaction with SSCS of a lower safety designation also has been considered, as required by WHC-CM-4-46, Section 9.0. The CVDS conceptual design and the safety-ciass designations developed in Chapter 4.0 demonstrate that the CVDS facility will adequately confine its design basis inventory under norma? and accident conditions.

This PSE has been prepared in accordance with the requirements identified in WHC-CM-4-46, Section 5.0, "Preliminary Safety Evaluation." It is not intended that the format of this PSE follow DOE-STD-3009-94, Preparation Guide for U.S. Department of Energy Nonreactor Nuclear Facility Safety Analysis Reports, because the PSE is not the safety analysis report required by DOE Order 5480.23. The final safety analys is report (FSAR) for the CVDS will 
be prepared in accordance with DOE-STD-3009-94 and will conform to the requirements of DOE Order 5480.23. The CVDS FSAR will contain a finalized list of safety-class and safety-significant SSCs based on the CVDS's physical configuration and the applicable supporting analysis.

This PSE addresses implementation of NRC nuclear safety equivalency as it relates to safety classification. It is not intended that this PSE achieve equivalency to NRC requirements for the performance of accident analyses for independent spent fuel storage installations, as defined in NRC Regulatory Guide 3.48, standard Format and Content for the Safety Analysis Report for an Independent Spent Fuel Storage Installation or Monitored Retrievable Storage Installation (Dry Storage) (NRC 1989). Such equivalency will be achieved by the CVDS FSAR. 
WHC-SD-SNF-PSE-003 REV 0

This page intentionally left blank. 


\subsection{DESIGN CRITERIA}

\subsection{FACILITY AND PROCESS DESCRIPTIONS}

The following CVDS facility descriptions and process drawings are from WHC-SD-SNF-CDR-003, Cold Vacuum Drying System Conceptual Design Report (Merrick 1996), where more detailed design information can be found.

\subsubsection{Facility Description}

The CVDS will be a new facility located to the west of the K Basin West Power Control Building as shown in Figure 2-1. The CVDS will consist of a fenced-off area surrounding a building structure, transport access staging area, various outside equipment, and utility connections as shown in Figure 2-2. The CVDS building will be a steel frame structure on a concrete pad. Architectural perspectives and elevations of the facility structure are shown in Figures $2-3,2-4$, and 2-5.

The facility building will contain process bays in which transport trailers can be contained while the free water is drained and a vacuum-gas purge process dries the SNF. A support area in the CVDS will contain a control room, change rooms, and other features required to support and coordinate operations. The facility floor plan is shown in Figure 2-6.

The CVDS building includes six independent bays where transport trailers will be parked and processed. Truck access to each bay will be through overhead garage doors along the east side of the buitding. The bays are connected by a corridor that runs along the west side of the building. The corridor will allow personnel access to the bays through step off pads, as well as acting as a chase for service header piping and conduits. Each bay will be an independent nuclear material secondary confinement structure that will block release to the outside environment should an accident or natural phenomena hazard (NPH) cause a release from the drying process. Each bay will be served by a dedicated ventilation system that will circulate and filter air through high-efficiency particulate air filters, as well as exhaust process exhaust, and vent streams and air collected from a hood at the top of the MCO where connections are made and broken. These exhausts will be collected in a stack that will be monitored to detect radioactive emissions.

Each bay will have a separate process equipment skid containing all of the processing equipment. A flow diagram of the process is shown in Figure 2-7. Ports in the MCO will be connected to hoses that lead to the process equipment skid. The process equipment is capable of drawing the $K$ Basin water contained in the MCO into a collection system, and purging warm dry gas through the MCO or pulling a vacuum on the MCO. A programmable logic controller will direct a sequence of purge or vacuum cycles that will dry the contents of the MCO. The equipment also will include a hot and chilled water system that will establish and control the temperature of the MCO during the drying process. The cold vacuum drying process is described in detail in Section 2.1.2. 
Figure 2-1. Location of the Cold Vacuum Drying System.

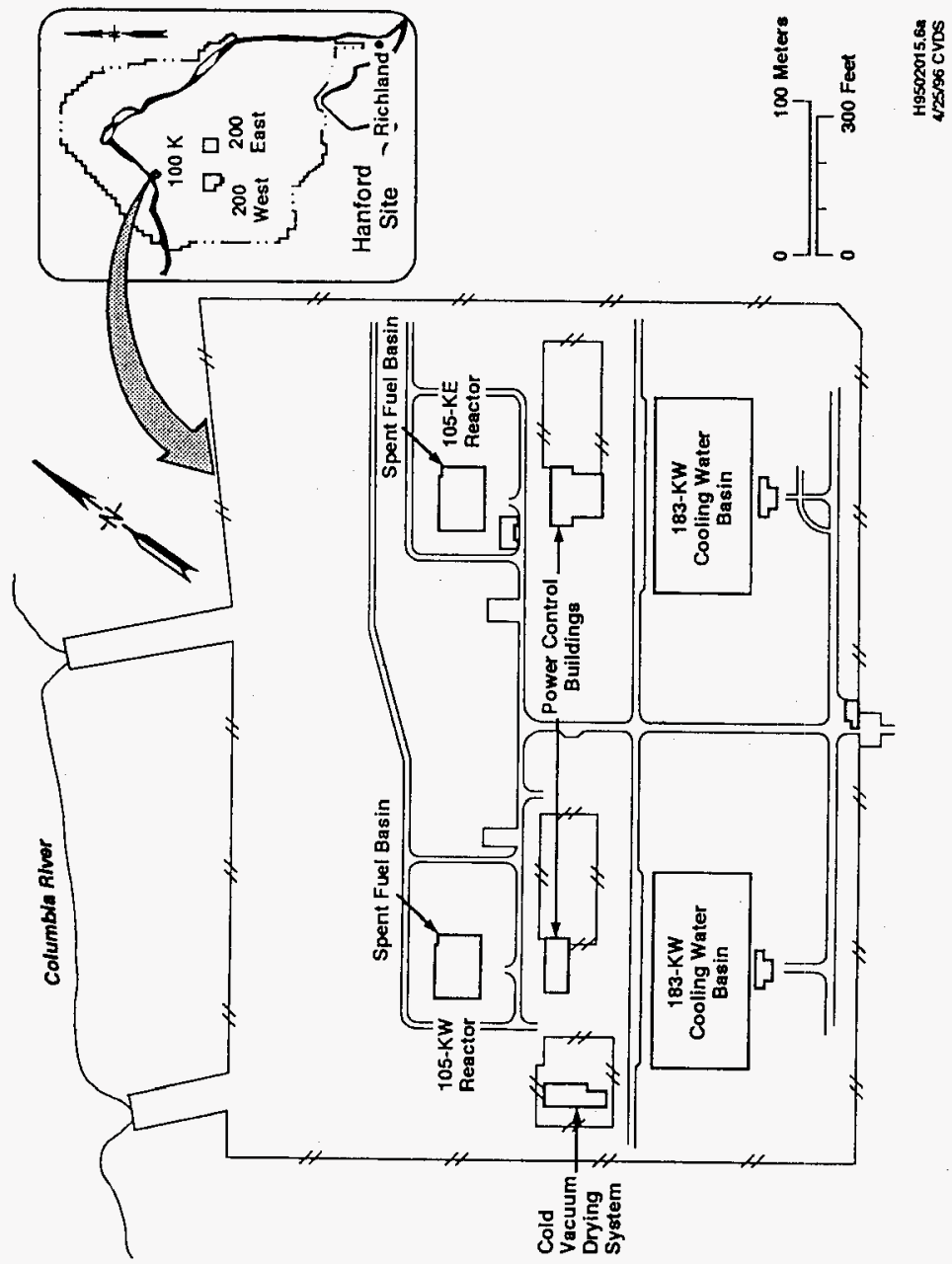




\section{WHC-SD-SNF-PSE-003 REV 0}

Figure 2-2. Site Plan for the Cold Vacuum Drying System Facility.

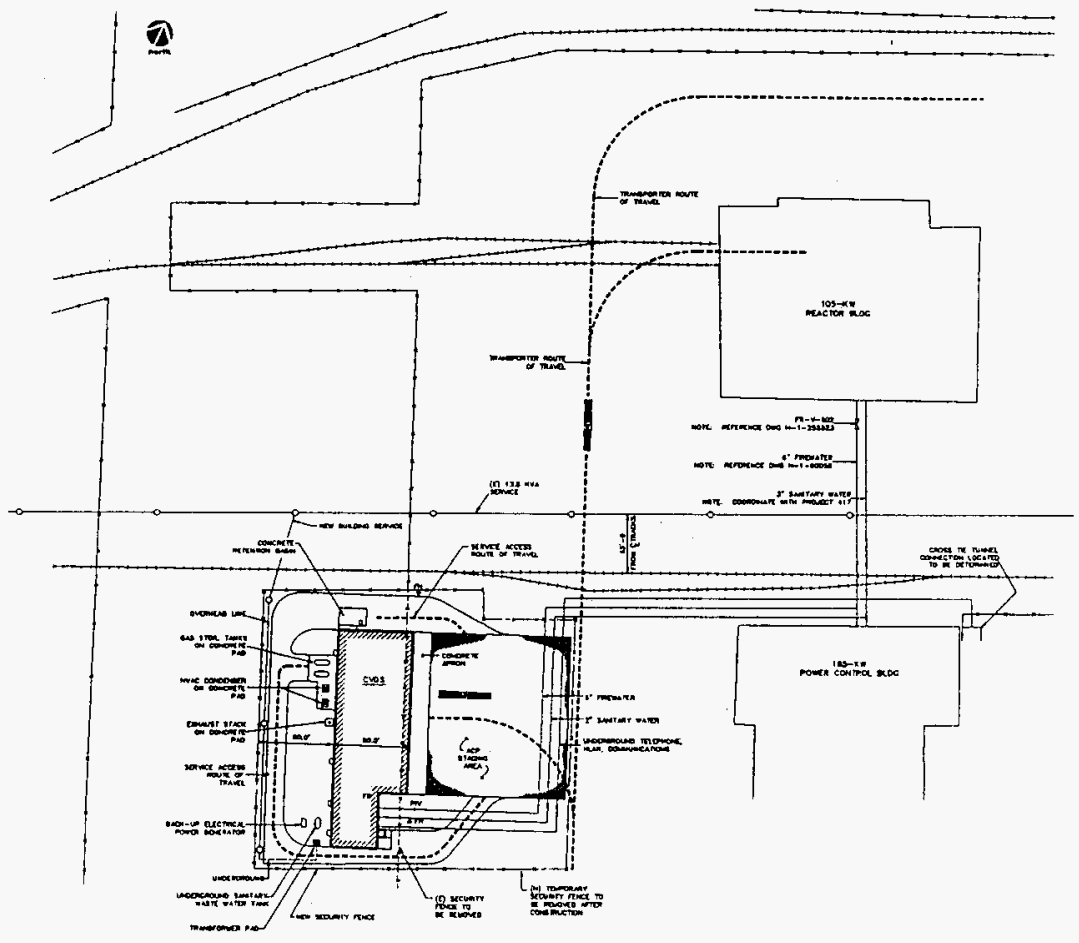


Figure 2-3. Architectural Perspective of the Cold Vacuum Drying system Building as Seen from the West.

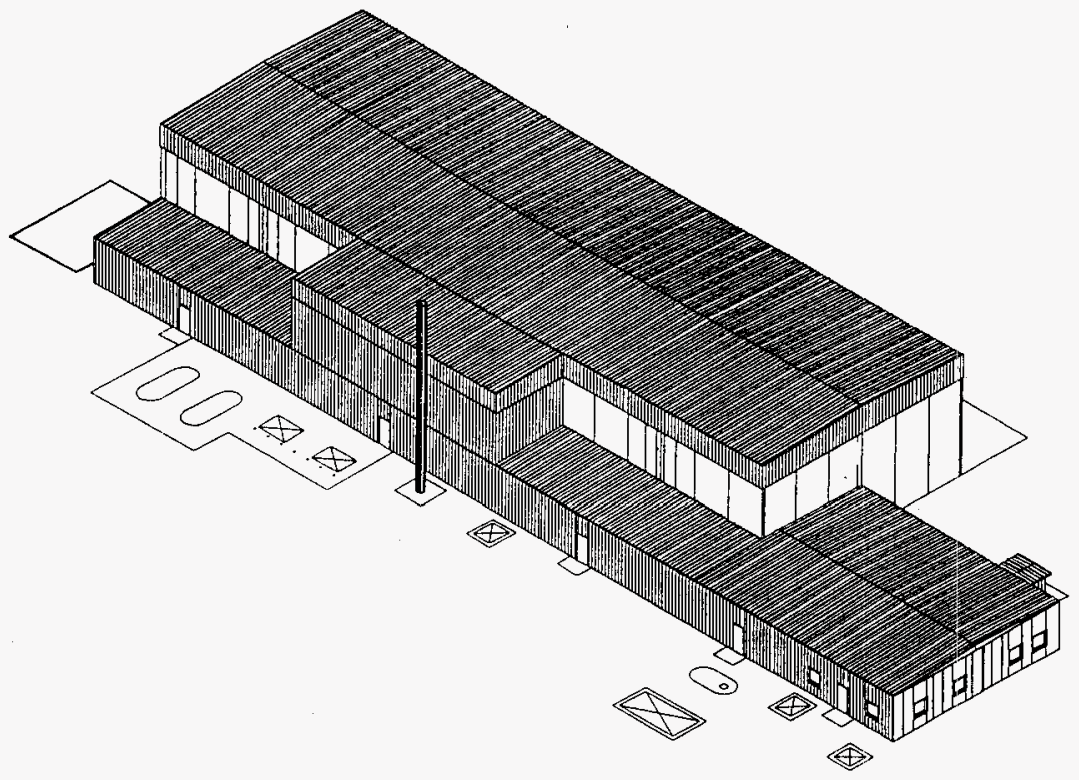


Figure 2-4. Architectural Perspective of the Cold Vacuum Drying System Building as Seen from the East.

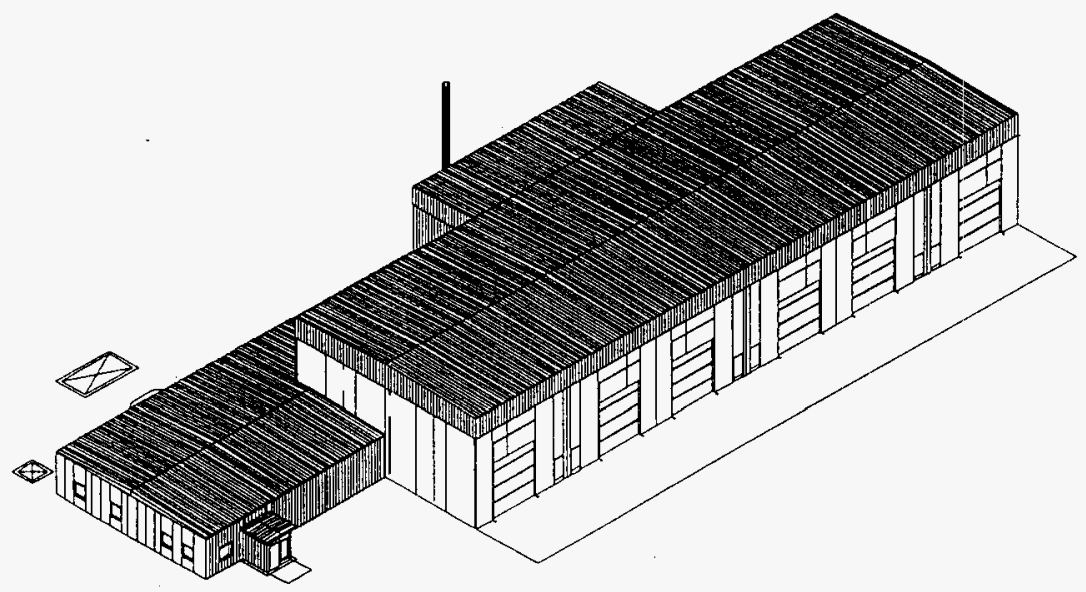


Figure 2-5. Architectural Elevations of the Cold Vacuum Drying System Building.

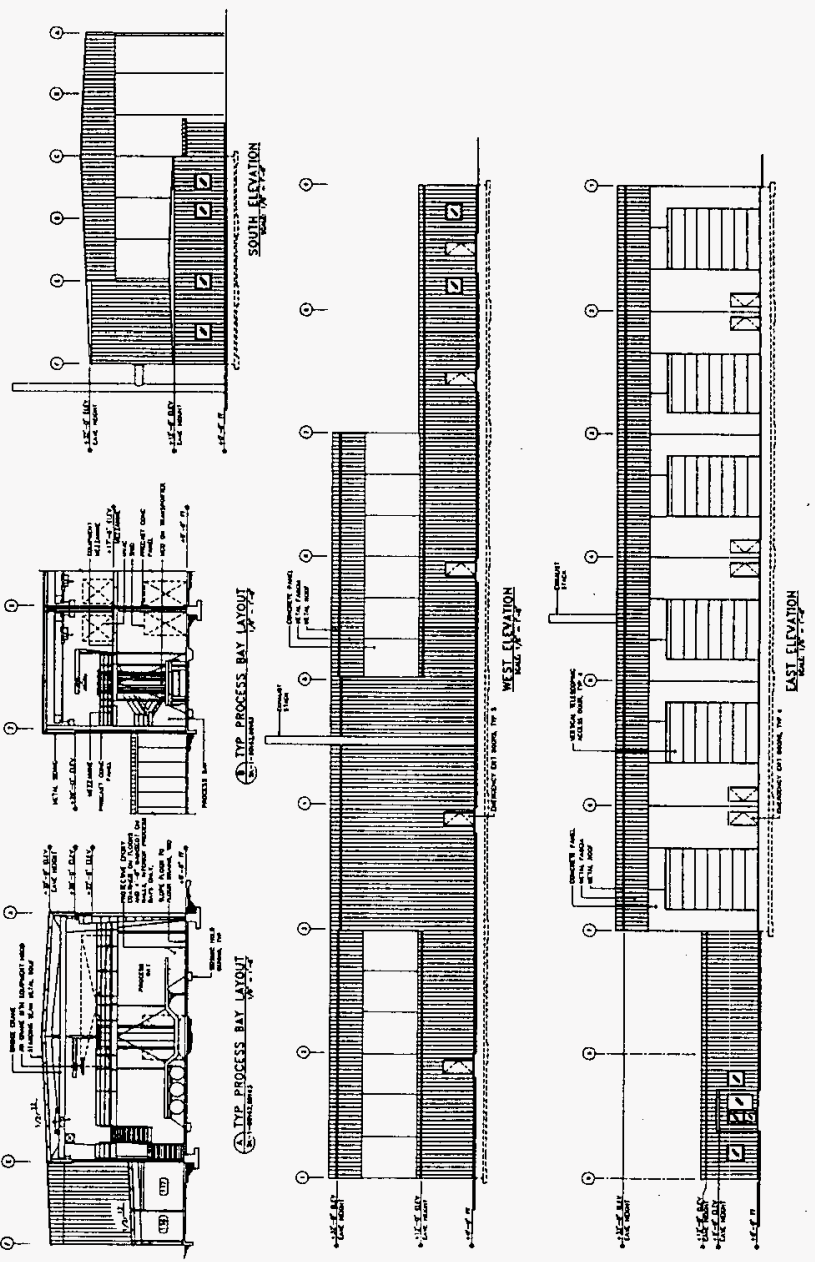


Figure 2-6. Cold Vacuum Drying System Building Floor Plan.

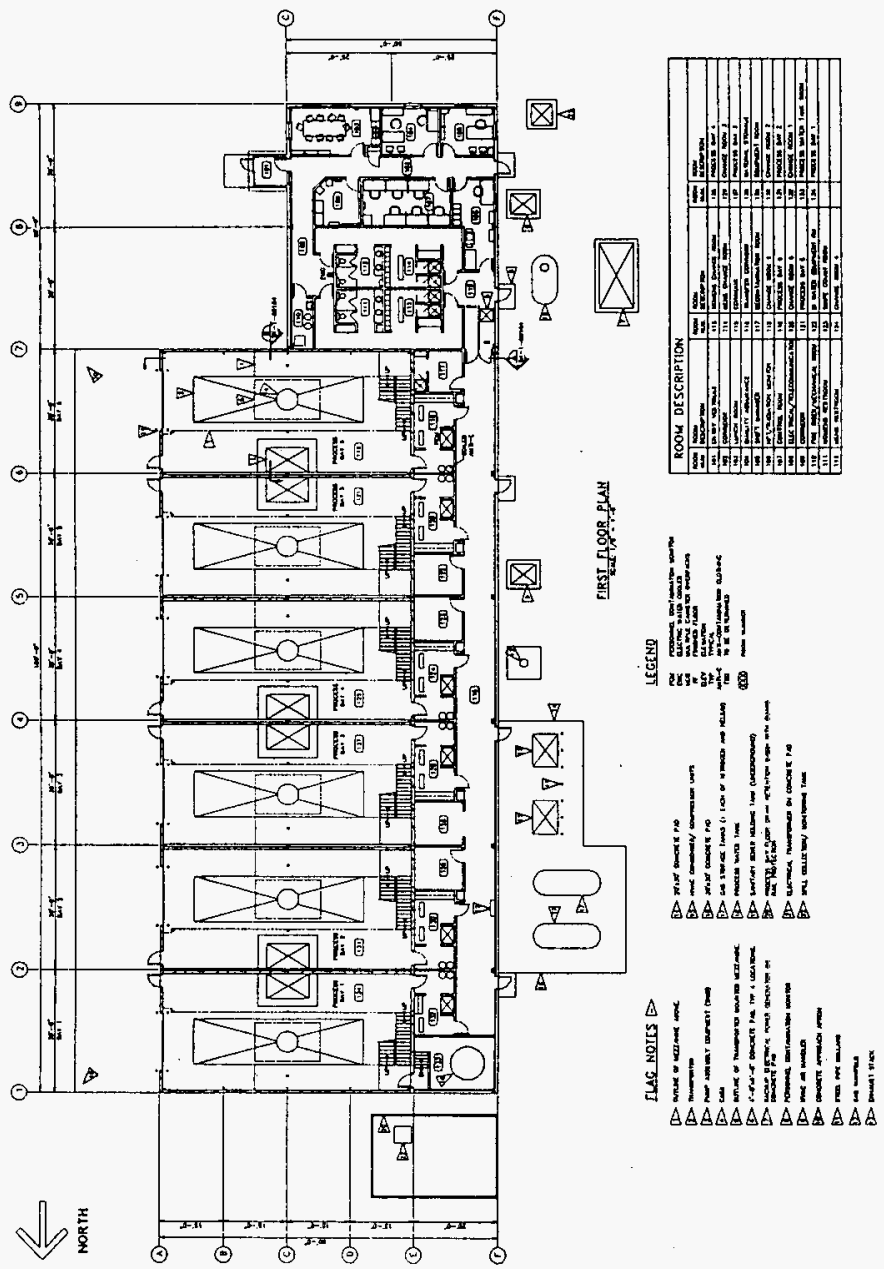


Figure 2-7. Flow Diagram of Cold Vacuum Drying Process.

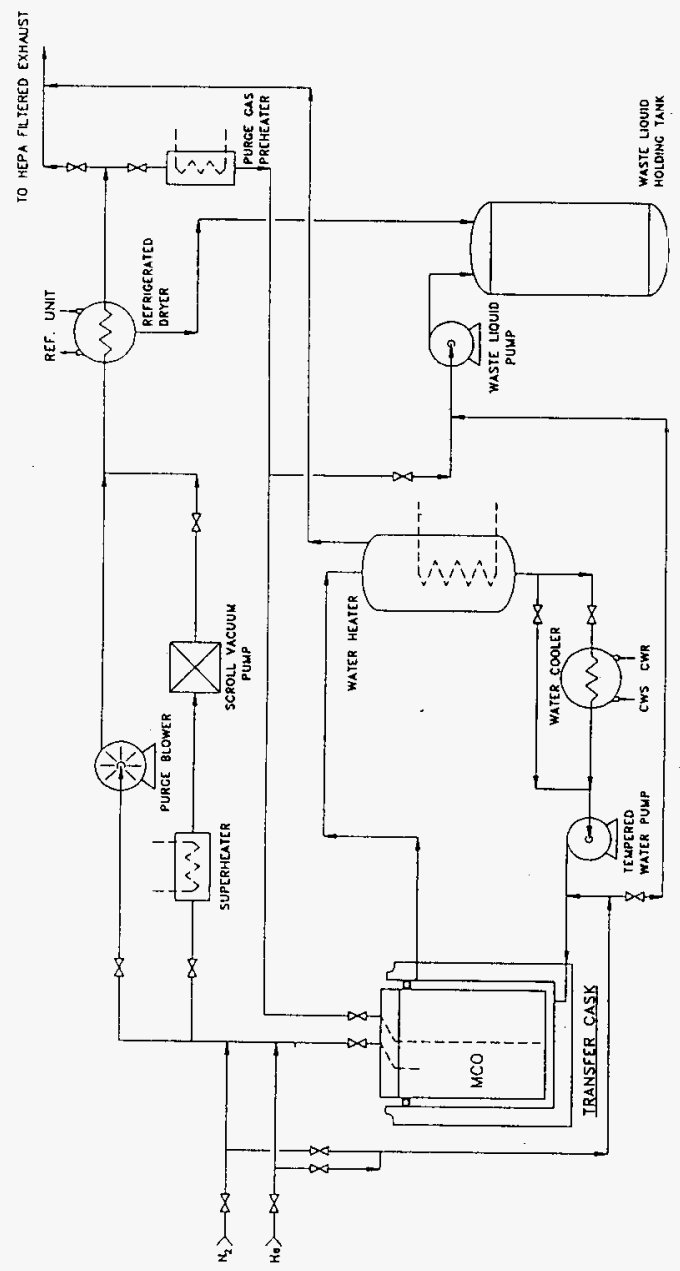


Other mechanical systems that are distributed to each bay to support the process include chilled water, compressed air, fire suppression water, radioactive liquid waste collection, gases, and potable water. There will be no sanitary sewer connection to the CVDS. Sewage will be collected in a tank and transferred to a tanker truck that will haul it to a sewage treatment plant offsite. Radioactive liquid waste also will be collected in a tank and transferred to a tanker truck periodically. The radioactive liquid waste will be disposed of at an outside location yet to be determined. Electrical power will be distributed to each process skid, the ventilation fans, the chiller and air compressor, the lighting system, and to other smaller loads. The power source will be an overhead line carrying $13.8 \mathrm{KV}$ three-phase power. A transformer and switch gear will be provided to derive $480 / 277$ VAC three-phase power and 208/120 VAC power for distribution throughout the facility.

\subsubsection{Process Description}

The planned sequence of activities between the time that an MCO is ready for shipping from the $K$ Basins untit the CVDS drying bay is ready to receive another MCO are summarized as follows:

1. Transport and Receipt. $K$ Basin workers will notify the cvos control room that a shipment is ready. The CVDS control room will select a bay and notify the truck driver who will drive to the CVDS and position the transporter trailer in front of the door. The door will be opened and an elephant-trunk exhauster will be attached to the truck's exhaust pipe so that diesel fumes do not enter the CVDS while the transporter is being positioned in the bay. The truck will back in and locate the transporter.

2. Preparation. Once the MCO has been accepted, the trailer will be secured, and the tractor will be disconnected and driven out of the CVDS.

3. Receiving Inspection and Acceptance. A group of receiving inspection activities will be performed to verify that the MCO is properly labeled so special nuclear material accountability is maintained, to verify that there is no removable contamination on the exposed surfaces of the shipping cask or MCO, and to assay the radiation field in the vicinity of the cask and the top of the MCO where workers will be present. Decontamination and resurvey will occur if contamination is found.

4. System Connection. After the shipping cask-MCO assembly is secured and determined to be free of contamination, radiation monitoring instrumentation will be attached to the transporter work platform and activated; water hoses will be attached to the cask ports; an overhead boom that carries a local exhaust hood and the process connection spools will be swung in; and the process hoses will be attached to the MCO top ports. 
5. Processing. Process activities include heating the MCO to the drying temperature (the water is left in the MCO in order to obtain effective heat transfer to the materials inside); draining the water from the MCO; executing a sequence of purge and evacuation cycles; verifying dryness by means of a pressure decay test; backfilling with helium; and cooling the cask. All these operations will be run from the control room.

6. Post-Processing. These are the reverse of the preparation activities. The process hoses are disconnected and handled as contaminated items (i.e., ends are bagged). The boom is swing out of the way. The water in the annular space between the shipping cask and the MCO is drained. The cask top is placed, sealed, and the annular space dried. Helium is injected into the annular space and the cask is leak checked. Instruments are removed from the transporter. The tractor arrives and is connected to the transporter. The transporter is released and driven away.

7. Bay Restoration. Cleanup includes floor mopping, filter changes, contaminated spool change-out or cleanup, and equipment calibrations.

\subsection{DESIGN REQUIREMENTS}

The CVDS will be designed to the requirements of DOE Order 6430.1A, the $K$ Basins SNF Project Regulatory Policy (Grumbly 1995), and the standards listed in DOE Order 5480.4, Environmental Protection, Safety, and Health Protection Standards. Additional design criteria for the CVDS are defined in codes and standards 1 isted in WHC-S-0435, Performance Specification for the $K-B a \sin$ SNF Low Temperature Vacuum Drying Module (Irwin 1996).

\subsubsection{Safety Classification Criteria}

The recommendations in the PSE for safety-class and safety-significant SSCs are derived from the guidelines in WHC-CM-4-46, Section 9.0, which implement DOE Order 6430.1A, Section 1300-3, "Safety Class Criteria;" and from WHC-SD-SNF-DB-003, Spent Nuclear Fuel Project Path Forward Additional NRC Requirements (Garvin 1995), which identifies items to be considered in achieving NRC nuclear safety equivalency. The Westinghouse Hanford Company (WHC) system for classifying items is based on potential radiological releases should the item fail:

- Safety-class items are those SSCs whose failure may result in a release that will expose the public offsite to radiological doses in excess of $5 \mathrm{mSV}(0.5 \mathrm{rem})$ effective dose equivalent (EDE)

- Safety-significant items are those SSCs whose failure may result in a release that will expose the onsite worker to radiological doses in excess of $50 \mathrm{mSv}$ ( $5 \mathrm{rem}$ ) EDE. 
SSCs whose failure could prevent safety-class or safety-significant SSCS from adequately performing their safety function, either by loss of control or monitoring function or by damage through physical interaction, are classified in correspondence with the SSC being protected.

In addition, implementation of NRC nuclear safety equivalency discussed in Section 1.1 has established an additional requirement for safety class 2 and 3 SSCs (now safety-significant SSCS) as documented in WHC-SD-SNF-DB-003 (Garvin 1995). NRC nuclear safety equivalency requires the use of a deterministic value of $50 \mathrm{mSv}$ ( $5 \mathrm{rem}$ ) in safety analyses for the onsite worker at the boundary of the controlled area (defined as $100 \mathrm{~m}$ [328 ft] from the facility release point) for design basis accidents to assist in determining safety class 2 and 3 SSCs (Garvin 1995). This is as opposed to the onsite probabilistic values in WHC-CM-4-46, Section 9.0.

Table 2-1 provides the preliminary list of safety-class and safetysignificant SSCS that have been identified based on the above criteria and on the analysis in Chapter 4.0, "Accident Evaluation." At the time of PSE initiation and development, assumptions were made based upon the CVDS Conceptual Design Report (Merrick 1996). Since then, some of the assumptions have changed, which may enable simpler, more cost-and schedule-effective mitigating design features. An example of such a mitigating feature may be localized process confinement over the MCO-cask.

\subsubsection{Natural Phenomena Hazards}

The CVDS design requirements for NPHs are established in WHC-SD-SNF-DB-010, Cold Vacuum Dry System Natural Phenomena Hazards (Tallman 1996). That document establishes the NPH load criteria discussed in the following sections.

2.2.2.1 Seismic Criteria. Seismic design must follow, as a minimum, DOE Order 5480.28, Natural Phenomena Hazards Mitigation, and the supporting standard DOE-STD-1020-94, Natural Phenomena Hazards Design and Evaluation Criteria for Department of Energy Facilities. The zero period acceleration for a performance category 3 facility in the $100 \mathrm{~K}$ Area, such as the CVDS, is $0.26 \mathrm{~g}$.

2.2.2.2 Wind and Tornado Criteria. The CVOS will be designed for a fastest mile wind of $129 \mathrm{~km} / \mathrm{h}(80 \mathrm{mi} / \mathrm{h})$ at $9 \mathrm{~m}(30 \mathrm{ft})$ above the highest finished grade. The following are the tornado criteria for safety-class SSCs (these criteria reflect the NRC reduction in Washington Public Power Supply System's Nuclear Plant 2 tornado criteria [C] ifford 1996 and Parrish 1995]):

- Wind speed

- $322 \mathrm{~km} / \mathrm{h}(200 \mathrm{mi} / \mathrm{h})$ total

- $257 \mathrm{~km} / \mathrm{h}(160 \mathrm{mi} / \mathrm{h})$ rotational

- $64 \mathrm{~km} / \mathrm{h}(40 \mathrm{mi} / \mathrm{h})$ translational

- Pressure drop

$$
\text { - 6,205 Pa }\left(0.901 \mathrm{~b} / \mathrm{in}^{2}\right) \text { at } 2,068 \mathrm{~Pa} / \mathrm{s}\left(0.30 \mathrm{lb} / \mathrm{in}^{2} / \mathrm{s}\right)
$$


Table 2-1. Preliminary List of Safety-Class Structures, Systems, and Components Required for the Cold Vacuum Drying System.

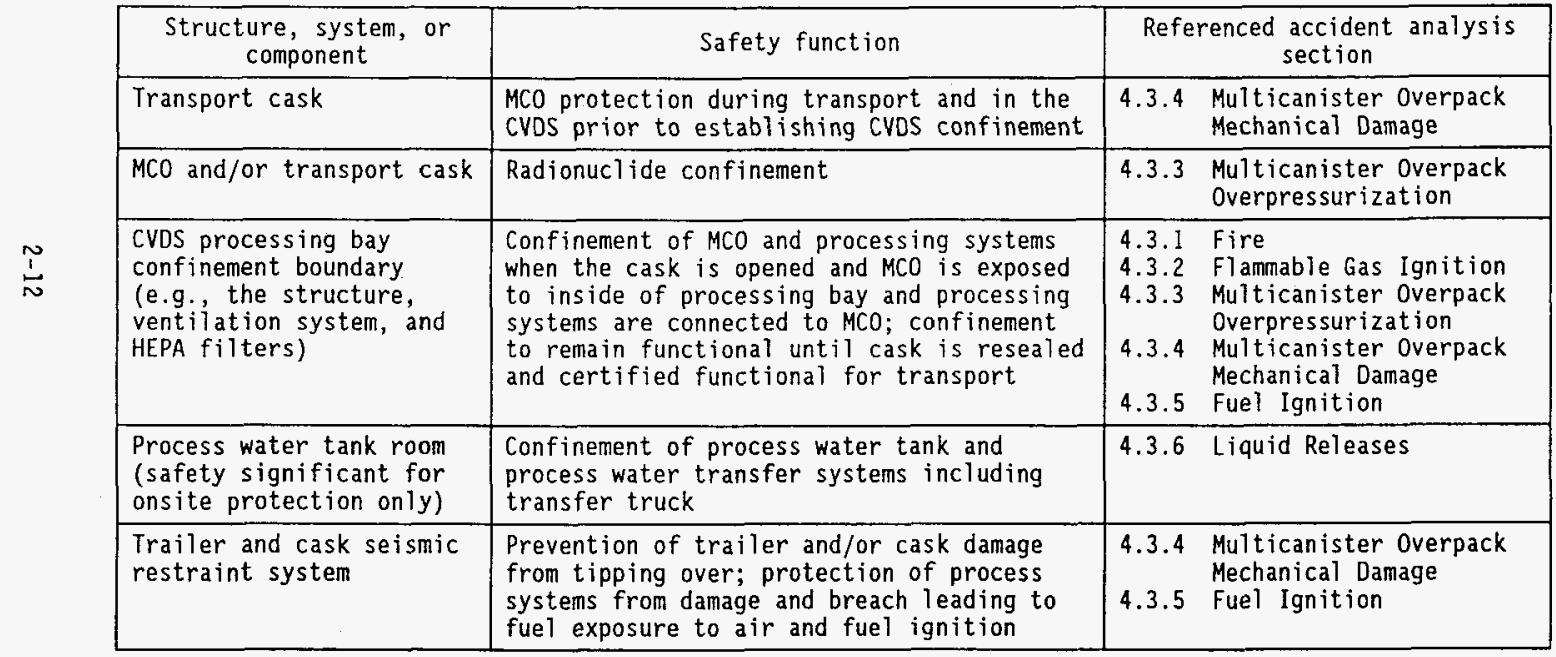

cvos = Cold Vacum Drying System.

HEPA = high-efficiency particulate air (filter). 
- Missiles

- Wood plank

$52 \mathrm{~kg}(115 \mathrm{lb})$

$0.09 \mathrm{~m} \times 0.29 \mathrm{~m} \times 3.66 \mathrm{~m}(3.6 \mathrm{in.} \times 0.94 \mathrm{ft} \times 12 \mathrm{ft})$

$49.3 \mathrm{~m} / \mathrm{s}(161.7 \mathrm{ft} / \mathrm{s})$ horizontal impact velocity

- 6-in. schedule 40 pipe

$130 \mathrm{~kg}$ (287 1b)

$0.17 \mathrm{~m}$ diameter $\times 4.57 \mathrm{~m}(6.6 \mathrm{in}$. diameter $\times 15 \mathrm{ft})$

$8.2 \mathrm{~m} / \mathrm{s}(27.0 \mathrm{ft} / \mathrm{s})$ horizontal impact velocity

- 2.5-cm (l-in.) steel rod

$4 \mathrm{~kg}(8.8 \mathrm{lb})$

$0.03 \mathrm{~m}$ diameter $\times 0.91 \mathrm{~m}$ ( 1 in. diameter $\times 3 \mathrm{ft}$ )

$7.6 \mathrm{~m} / \mathrm{s}(24.9 \mathrm{ft} / \mathrm{s})$ horizontal impact velocity

- Utility pole

$510 \mathrm{~kg}(1,124 \mathrm{lb})$

$0.34 \mathrm{~m}$ diameter $\times 10.67 \mathrm{~m}$ (13.5 in. diameter $\times 35 \mathrm{ft}$ )

$9.4 \mathrm{~m} / \mathrm{s}(30.7 \mathrm{ft} / \mathrm{s})$ horizontal impact velocity

- 12-in. schedule 40 pipe

$340 \mathrm{~kg}(750 \mathrm{lb})$

$0.32 \mathrm{~m}$ diameter $\times 4.57 \mathrm{~m}$ (12.75 in. diameter $\times 15 \mathrm{ft}$ )

$6.6 \mathrm{~m} / \mathrm{s}(21.8 \mathrm{ft} / \mathrm{s})$ horizontal impact velocity

- Automobile

$1,810 \mathrm{~kg}(3,990 \mathrm{lb})$

$5.0 \mathrm{~m} \times 2.01 \mathrm{~m} \times 1.31 \mathrm{~m}(16.4 \mathrm{ft} \times 6.6 \mathrm{ft} \times 4.3 \mathrm{ft})$

$32.1 \mathrm{~m} / \mathrm{s}(105.2 \mathrm{ft} / \mathrm{s})$ horizontal impact velocity.

Missiles are considered to strike surfaces in any direction, and vertical velocities are $70 \%$ of the horizontal velocities except for the $2.5-\mathrm{cm}(1-\mathrm{in}$.) steel rod, which has the same velocity in any direction. The utility pole and automobile are considered to strike surfaces up to a maximum of $9.1 \mathrm{~m}(30 \mathrm{ft})$ above the highest finished grade within $0.8 \mathrm{~km}(0.5 \mathrm{mi})$ of the plant. The other missiles can strike at any elevation.

2.2.2.3 Volcanic Ash Criterion. The ashfall criterion for the performance category 3 portions of the CVDS (i.e., the safety-class portions), is $15 \mathrm{~cm}$ (6 in.) of uncompacted ash, which represents $7.5 \mathrm{~cm}$ (3 in.) of compacted ash. Using an average density for compacted ash of $1,538 \mathrm{~kg} / \mathrm{m}^{3}\left(96 \mathrm{lb} / \mathrm{ft}^{3}\right)$, the ground ash load of $7.5 \mathrm{~cm}$ (3 in.) of compacted ash is $385 \mathrm{~kg} / \mathrm{m}^{2}\left(24 \mathrm{ib} / \mathrm{ft}^{2}\right)$.

2.2.2.4 Flood Criteria. The CVDS site is at an elevation of about $140 \mathrm{~m}$ $(459 \mathrm{ft})$ above mean sea level. The Columbia River is closest to the CVDS at river kilometer 616 (mile 382) where the normal flow is at approximately $119 \mathrm{~m}$ $(390 \mathrm{ft})$ above mean sea jevel. At the same river kilometer, the estimated flood level for a $25 \%$ breach of Grand Coulee Dam is $140 \mathrm{~m}$ (460 ft). 
The probable maximum precipitation established for the CVDS site is $23 \mathrm{~cm}$ (9.2 in.) when considering a $1-\mathrm{mi}^{2}$ area and approximately $19 \mathrm{~cm}(7.4 \mathrm{in}$.) when considering a $10-\mathrm{mi}^{2}$ area (TaTlman 1995).

2.2.2.5 Snow Load. The design snow load is $98 \mathrm{~kg} / \mathrm{m}^{2}\left(201 \mathrm{~b} / \mathrm{ft}^{2}\right)$.

\subsubsection{Decontamination and Decomissioning}

The design of the CVDS facilitates decontamination so that the facility can be decommissioned at a future date. Guidance for design of retrieval equipment to facilitate eventual decommissioning will be obtained from DOE Order 4700.1, Project Management System; DOE Order 5820.2A, Radioactive Waste Management; DOE Order 6430.1A, Sections 1300-11.2 and 1321-7; and Title 10, Code of Federal Regulations, Part 72, "Licensing Requirements for the Independent Storage of Spent Nuclear Fuel and High-Level Radioactive Waste," Section 72.130, "Criteria for Decommissioning." 


\subsection{HAZARDOUS INVENTORIES}

\subsection{RADIOACTIVE INVENTORY}

The CVDS facility's maximum radiological inventory is based on six MCOs in the facility at one time. Each MCO would contain a maximum of 270 MKIV fuel elements and a maximum of $700 \mathrm{~L}$ (185 gal) of $\mathrm{K}$ Basin water. This section describes the radiological material inventory of the $K$ Basin spent fuel.

The $K$ Basin fuel is characterized in WHC-SD-SNF-TI-009, 105-K Bas in Material Design Feed Description for Spent Nuclear Fuel Project Facilities (Willis 1995). That document develops a safety-regulatory assessment design basis inventory based on selecting the fuel that would result in the highest estimated dose to people exposed to the material. The radiological inventory of the safety-regulatory assessment design basis fuel is given in Table 3-1.

Accountability records were used as a basis for the quantity, exposure variation, and decay time variation of the stored fuel. Radionuclide estimates were effectively derived from two computer models.

- ORIGEN2 (Croff 1980) runs for $N$ Reactor fuel provided radionuclide compositions for discharged fuel at selected exposure leveis.

- RADNUC (Schwarz 1995) combined the ORIGEN2 fuel compositions at selected points with accountability data on exposure and decay time to generate a composite radionuclide inventory decayed to a common date.

Only those isotopes contributing more than $0.1 \%$ to the inhatation dose are reported. In addition, ${ }^{3} \mathrm{H}$ and ${ }^{85} \mathrm{Kr}$ are reported because the release fraction and exposure pathway can be very different for these isotopes. It should be noted that the transuranic elements account for $99.5 \%$ or more of the effective dose.

\subsection{HAZARDOUS MATERIAL INVENTORY}

The only routine use of chemicals within the CVDS will be for decontamination of the process station and equipment after drying an MCO. Decontamination will likely require use only of water and detergent. However, chemical solvents may be used. Purging and backfilling of the MCOs will involve the use of an inert gas. There are no known toxicological inventories of concern for safety anaiysis considerations. 


\section{WHC-SD-SNF-PSE-003 REV 0}

Table 3-1. Radiological Analys is of $K$ Basin Fue (Decayed to $1 / 1 / 95$ ).

\begin{tabular}{|c|c|}
\hline Radionuclide & Activity (Ci /MTU)* \\
\hline${ }^{3} \mathrm{H}$ & $3.57 \mathrm{E}+01$ \\
\hline${ }^{85} \mathrm{Kr}$ & $5.39 \mathrm{E}+02$ \\
\hline${ }^{90} \mathrm{Sr}$ & $7.84 \mathrm{E}+03$ \\
\hline${ }^{90} \mathrm{Y}$ & $7.84 \mathrm{E}+03$ \\
\hline${ }^{137} \mathrm{Cs}$ & $1.08 \mathrm{E}+04$ \\
\hline${ }^{238} \mathrm{Pu}$ & $1.71 \mathrm{E}+02$ \\
\hline${ }^{239} \mathrm{Pu}$ & $1.58 \mathrm{E}+02$ \\
\hline${ }^{240} \mathrm{Pu}$ & $1.28 \mathrm{E}+02$ \\
\hline${ }^{249} \mathrm{Pu}$ & $9.25 \mathrm{E}+03$ \\
\hline${ }^{241} \mathrm{Am}$ & $3.58 \mathrm{E}+02$ \\
\hline${ }^{244} \mathrm{Cm}$ & $5.36 \mathrm{E}+00$ \\
\hline
\end{tabular}

Notes:

$\star 1.0 \mathrm{Ci}=3.7 \times 10^{10} \mathrm{~Bq}$.

MTU = metric tons uranium. 


\subsection{ACCIDENT EVALUATION}

The principal accidents of concern for the CVDS are those associated with radioactive material releases. The accidents associated with electrical, mechanical, or thermal energy are similar to those for other normal industrial operations and, therefore, are not addressed here. Release of nonradiological hazardous material is not analyzed because no use of such materials in the CVDS has been identified.

\subsection{PRELIMINARY HAZARD ANALYSIS}

An assessment team conducted a preliminary hazard analys is (PHA) to identify potential accidents in accordance with WHC-CM-4-46, Section 5.0, "Preliminary Safety Evaluation." The PHA satisfies the requirements of DOE Order 5480.23 and its implementing standard, DOE-STD-3009-94, for a systematic, rigorous technique for identifying the range of potential hazards posed by the operation of the CVDS. The PHA is attached as Appendix $A$.

The events identified by the PHA were further evaluated by establishing a potential accident and sequence, consequences, and mitigating or preventive features (engineered and administrative), and qualitatively estimating the probability of occurrence. The PHA provides a qualitative estimate of the unmitigated radiological consequences for each event.

The PHA process examined the CVDS facility activities, and identified the hazards associated with postulated accidents. The process steps during which the events happen are listed as follows:

1. Receiving the MCO into the facility

2. Restraining the trailer and cask in the station

3. Receiving inspection activities

4. Process connections

5. Process activities

6. Post-process activities

7. Solid waste removal

8. Natural phenomena or human-generated hazards.

Criteria for selecting accidents for further study were based on the qualitative consequences and likelihoods. A consequence category was assigned to each event, based on the potential hazardous inventory at risk for release, and a frequency of occurrence category was subjectively chosen. The frequency of occurrence category is qualitatively evaluated based on existing information and data to support frequency. If insufficient information and data are available, then the conservative higher frequency category is chosen. The key to the consequence category designations is in Table 4-1 and the key to the frequency category designations is in Table 4-2.

Only those items ranked as category $\$ 3$ were binned into major groupings based on the potential quantity of radioactive material available for release to the facility from the event. The PHA identified the following twelve 
potential hazard and accident categories for the CVDS facility (the numbers preceding each entry refer to corresponding entries in the PHA table in Appendix A).

Table 4-1. Consequence Categories.

\begin{tabular}{|c|l|}
\hline Category & \multicolumn{1}{|c|}{ Definition } \\
\hline So & $\begin{array}{l}\text { No effect outside the facility confinement systems and } \\
\text { no safety concerns for the facility worker, the onsite } \\
\text { worker, or members of the general public }\end{array}$ \\
\hline S1 & $\begin{array}{l}\text { Potential for injury, radiological dose consequences, } \\
\text { or chemical exposure to the facility worker; limited } \\
\text { environmental discharge of hazardous material outside } \\
\text { the facility }\end{array}$ \\
\hline S2 & $\begin{array}{l}\text { Potential significant radiological dose consequences or } \\
\text { chemical exposure to the onsite worker at the nearest } \\
\text { adjacent facility; significant environmental discharge } \\
\text { of hazardous material within the Hanford Site boundary }\end{array}$ \\
\hline S3 & $\begin{array}{l}\text { Potential significant radiological dose consequences or } \\
\text { chemical exposure to the offsite population; } \\
\text { environmental discharge of hazardous material outside } \\
\text { the Hanford Site boundary or to the groundwater }\end{array}$ \\
\hline
\end{tabular}

Table 4-2. Frequency Categories.

\begin{tabular}{|c|l|}
\hline Category & \multicolumn{1}{|c|}{ Definition } \\
\hline$F 3$ & Anticipated $\left(f>10^{-2} / y r\right)$ \\
\hline$F 2$ & Unlikely $\left(10^{-2} / y r>f>10^{-4} / y r\right)$ \\
\hline$F 1$ & Extremely unlikely $\left(10^{-4} / y r>f>10^{-6} / y r\right)$ \\
\hline F0 & Beyond extremely unlikely $\left(f<10^{-6}\right)$ \\
\hline
\end{tabular}

1. Fire

The truck's fuel tank breaches as a result of collision or other cause during receipt or removal of the trailer containing the shipping cask and MCO. Diesel fuel or gasoline spills onto the floor around the trailer. The spilled fossil fuel then ignites, and the fire spreads to other combustible materials in the receiving area. The $\mathrm{MCO}$ and cask are surrounded by $\mathrm{flames.} \mathrm{If} \mathrm{the} \mathrm{fire}$ occurs during receiving, the SNF is covered with water; if the fire 


\section{WHC-SD-SNF-PSE-003 REV 0}

occurs as the truck is leaving the facility, the SNF has been vacuum dried and the MCO has been backfilled with an inert cover gas.

\section{Potential accidents}

1.a Truck fire in receiving facility

S3, F2

7.a Airborne contamination caused by fire in contaminated solid waste materials accumulated in the facility

2. Flammable Gas Ignition

Chemical and radiolytic hydrogen production and subsequent mixing with oxygen-containing atmospheres could lead to hydrogen gas ignition that would release the MCO gases and particulates and potentially entrain greater amounts of particulates than would be the case with a simple depressurization.

Prior to purge or backfill, there has been a delay in processing. The MCO has been allowed to sit unvented long enough for hydrogen to build up in the MCO atmosphere. Because of an erroneously labeled gas bottle or an error in hooking up the correct gas bottle, a different gas than the intended purge gas is mistakenly introduced into the MCO. The gas that is introduced is assumed to be an oxidant (probably oxygen). The purge is initiated, and a flammable mixture results. An ignition source is assumed to exist, and the flammable mixture ignites.

\section{Potential accidents}

3.d Excessive hydrogen generation caused by pressurized release from cask during 1 id removal (with fuel uncovered)

5.a Excessive hydrogen generation caused by cask overheating

5.g Hydrogen buildup from fuel/water/water vapor reactions caused by failure to completely drain MCO

5.k Increased radiolytic hydrogen production caused by backflow of pump oil into MCO

5.9 Flammable gas mixture present as a result of error in type of gas introduced as purge gas (wrong gas in tank)

5.x Wrong gas in tank S3, F3

5.y Contaminated gas $\mathrm{SO}, \mathrm{F3}$ 


\section{MCO Pressurization}

A pressurized release could potentially involve the MCO atmosphere and the entire inventory of particulate material in the $\mathrm{MCO}$.

Scenario 1. Because of a delay in shipping from the basins, and/or a delay in beginning processing at the CVDS, radiolytically generated gases build up in the unvented MCO. Because the MCO is flooded, the gas space is small. The pressure inside the MCO builds up until the pressure relief device opens. Gas from the MCO atmosphere, including suspended droplets of the water ( $K$ Basin water), are released to the facility.

Scenario 2. A normal or inadvertent initiation of the inert gas purge of the MCO occurs with the MCO at maximum operating temperature. The purge control valve fails and the pressure builds up until the MCO pressure relief device actuates. The MCD atmosphere, including loose particulates, will be released through the opening. The release may continue over a period of time because the excess volume of gas in the $M C O$ will continue to vent until the pressure reaches 1 atm. (Air will be entering through the draw tube near the MCO bottom, so the flow could pick up loose particulate from the fuel surfaces before it exits the MCO.)

\section{Potential accidents}

3.d Excessive hydrogen generation caused by pressurized release from cask during lid removal (with fuel uncovered)

4.b Particulate blowout of MCO during pressurization of $\mathrm{MCO}$ with purge gas.

S3, F3

5. a Release of gases as a result of pressurization caused by cask overheating

$5 . i$ Pressurization of MCO by purge gas during purge or vent cycle

S3, F2

5.k MCO pressurization caused by backflow of pump $0 i 1$ into $\mathrm{MCO}$

S3, F2

5.1 Pressurization of MCO because vacuum pump installed backwards

S3, F2

5.v Pressurization during backfill

S3, F2

5.y Contaminated gas

SO, F3

6.d Pressurized release from MCO resulting from failure of connections of $\mathrm{MCO}$

$\mathrm{S3}, \mathrm{F3}$ 
6.0 Pressurization and heatup of MCO resulting from failure to ship within shipping window

4. MCO Mechanical Damage

Any of the following accidents could lead to damage to the cask, $\mathrm{MCO}$, or other equipment.

\section{Potential accidents}

1.c Cask/trailer tipping or collision during receiving S3, F2

1.d Damage to the cask-MCO system or supporting equipment caused by truck collision

S3, F2

1.e Damage to cask-MCO system or supporting equipment and facility damage caused by runaway truck

2. a Cask damage during process of removing tractor and securing trailer resulting in damage to adjacent stations

S3, F2

3.a Loss of control of cask 1id plug during removal

$\mathrm{S2}, \mathrm{F} 2$

4.a Damage to MCO fittings by dropped process hood

5.b Collapse of MCO while under vacuum as a result of inadvertent overheating of the annulus during heating cycle

5.p MCO buckling and breach of MCO or cask seal during collapse of MCO caused by external pressure

6.c Dropped process hood

6.g Overpressurization of cask caused by incomplete draining of annulus

6.h Dropped cask lid

6.j Failure of $M C O$ (or $M C O$ rupture disC) as a result of overpressurized cask

6.n Building damage because of failure to remove seismic restraint 


\section{SNF Ignition}

After the MCO is drained, a control circuit failure or human error causes uncontrolled heating of the water in the annulus. The temperature of the water circulating in the annulus reaches $100{ }^{\circ} \mathrm{C}$. The error is not immediately discovered and corrected, so the MCO wall continues to be heated for some period of time. The heat transferred to the MCO, combined with the decay heat of the SNF, begins to vaporize the free water remaining in the MCO. Ignition of the SNF results, with resulting release of particulate material.

\section{Potential accidents}

1.g Uncovered fuel in $\mathrm{MCO}$ resulting from error in pumping out $\mathrm{MCO}$ at $\mathrm{K}$ Basin

3.e Ignition resulting from pressurized release from cask during lid removal (with fuel uncovered)

5.c Long-term uncovering and igniting caused by steam formation in MCO because of heating

5.g Fuel ignition from fuel/water/water vapor reactions caused by failure to completely drain MCO

5.j Missile caused by catastrophic loss of cooling system

5.I Fuel ignition caused by introduction of air into MCO

5.m Water sucked back into MCO from drain tank because of valve misalignment

S3, F3

5.0 Overfill of condenser tank

5.q Fuel ignition from reactive gas present as a result of error in type of gas introduced as purge gas (wrong gas in tank)

5.s Fuel ignition from reactive gas present because of error in type of gas introduced as backfill gas (wrong gas in tank)

5.t Missile caused by catastrophic failure of the sample pump during monitoring damages adjacent equipment

5.x Wrong gas in tank

6. Liquid Releases

The PHA identified several sources of 1 iquid releases. Since all of the liquid under consideration for this category of events is MCO water, the limiting event is the one that deals with the largest 
quantity of this water. The largest quantity of MCO water in the CVDS that could be involved in a single incident would be the contents of the central liquid holding tank when filled to its capacity of $18,900 \mathrm{~L}(5,000 \mathrm{gal})$. There are two types of accidents dealing with this holding tank water: spill accidents and spray accidents. Spill accidents, such as the rupture of a connecting pipe or rupture of the tank itself, could result in spilling the entire contents of the tank onto the facility floor. Spray accidents, such as the spray resulting from a breacth of the pressurized line going from the pump to the tank truck during the operation of pumping the holding tank water to the tank truck, could result in the contents of the holding tank being sprayed into the atmosphere. These two types of accidents were evaluated to determine which type could result in the maximum dose at the site boundary.

\section{Potential accidents}

4.C Equipment contamination resulting from draining of $K$ Basin water into the facility and/or equipment from a breached MCO

4.d Release of contaminated water and particulates as a result of draining of annulus water into facility and/or equipment

5.e Loss of drain line integrity during draining resulting in spread of contaminated water

5.f Spread of contaminated water resulting from failure of drain tank

5.m Discharge of dirty water up the stack caused by sucking water back to the MCO from drain tank

5.n Liquid from drain tank sucked back into the vacuum pump

5.0 Overfill of condenser tank

6.g Overpressurization of cask as a result of incomplete draining of annulus

7.b Spray leak of liquid waste during pumping to main tank pumpout

7.c Spill of liquid waste during pumping to tanker truck S1, F3

Hazard and accident categories 7 through 10 involve only worker injuries and do not involve insignificant releases of radioactive materials. Therefore, they are not included in the accident analyses in Chapter 4.0 and no discussions of the potential accident scenarios are included. Category 11 
identifies criticality, which will be addressed in a separate criticality evaluation report and is listed as an open item for further resolution in Section 8.0. Category 12 identifies concerns for hazards later in the process that will be addressed in the safety documentation for transportation or for other facilities as appropriate.

7. Worker Asphyxiation

Potential accidents

1.b Worker exposure to exhaust gases in truck unloading area

$\mathrm{S1}, \mathrm{F3}$

5.d Worker exposure to oxygen-deficient atmosphere

$\mathrm{S1}, \mathrm{F} 2$

5.h Worker area flooded with inert gas as a result of break in purge gas line

6.b Worker asphyxiation (if inert gas purge line) caused by personnel exposure to a pressurized line

6.k Worker exposure to oxygen-deficient atmosphere (vent is closed)

$\mathrm{S} 1, \mathrm{~F} 2$

8. Worker Burns

Potential accidents

5.d. Worker exposure to steam caused by inadvertent heating while activating the cooling system

6.k. Worker exposure to steam caused by inadvertent heating while activating the cooling system (vent is closed)

SI, F2

9. Worker Injury

Potential accidents

1.C Cask/trailer tipping or collision during receiving \$3, F2

1.d Damage to the cask-MCO system or supporting equipment caused by truck collision

S3, F2

1.e Damage to cask-MCO system or supporting equipment and facility damage from runaway truck

S3, F2

2.a Worker injury during process of removing tractor and securing trajler 
3.a Loss of control of cask lid plug during removal S1, F2

4.a Operation injury during the dropped process hood S1, F2

5. i Purge gas bottle becomes missile as a result of lack of proper restraint $\quad \mathrm{Sl}, \mathrm{F2}$

5.j Missile caused by catastrophic failure of the vacuum pump

$S 1, F 2$

5.t Missile caused by catastrophic failure of the sample pump during monitoring

S1, F2

5.v Pressurization during backfill

6.b Personnel exposure to pressurized line while removing hookups

$\mathrm{S1}, \mathrm{F3}$

6.C Dropped process hood

S1, F2

6.h Dropped cask lid

S1, F2

6 . $n$ Building damage because of failure to remove seismic restraint

$\mathrm{S3}, \mathrm{F3}$

10. Worker Contamination or Exposure to Radiation Field

\section{Potential accidents}

3.b Vent or pressure relief during transport or contamination at $\mathrm{K}$ Basins before shipping

$\mathrm{Sl}, \mathrm{F} 2$

3.c Worker contamination resulting from error in source term, shielding design, or survey at $K$ Basin

4.b Particulate blowout of MCO during pressurization of $\mathrm{MCO}$

4.d Release of contaminated water and particulates as a result of draining of annulus water into facility and/or equipment

$\mathrm{S1}, \mathrm{F3}$

5.d Exposure to steam caused by inadvertent heating while activating the cooling system

5.e Loss of drain line integrity during draining

5. i Gas or particulate release from $M C O$ as a result of steam in MCO from heating while activating cooling system 
6.a Exposure to contaminated piping while removing hookups

S1, F3

6.b Exposure to a pressurized line

$\mathrm{S1}, \mathrm{F3}$

6.k Exposure to steam caused by inadvertent heating while activating the cooling system (vent closed)

S1, F2

6.n Cask failure because of failure to remove seismic restraint

7.a Exposure or contamination as a result of mishanding of solid waste

7.b Spray leak of liquid waste during pumping to main tank pumpout

S3, F3

7.c Spill of liquid waste during pumping to tanker truck

S1, F3

11. Criticality

\section{Potential accidents}

5.k Backflow of vacuum pump oil into MCO

So, F2

5.r Contaminated purge gas (e.g. oil, or moisture)

So, $\mathrm{F3}$

5.y Contaminated gas

SO, F3

12. Concerns for Steps Further Along in the Process

\section{Potential accidents}

5.r Purge gas contaminated with oil or water used for final purge

So, F3

5. $u$ High residual water in $\mathrm{MCO}$

5.w Failure to backfill so that MCO is shipped without inert gas cover

5.y Contaminated gas

SO, F3

5.z Potential reaction with fuel at elevated temperature caused by backfill with nitrogen

6.aa Heatup and pressurization of $M C O$ because of failure to cool down before shipment to the CSB

6. $i$ Seal failure causing inadequate cask seal 
WHC-SD-SNF-PSE-003 REV 0

6.j Failure of MCO (or MCO rupture disc) caused by overpressurized cask

$\mathrm{S3}, \mathrm{F3}$

6.0 Pressurization and heatup of MCO resulting from the failure to ship within shipping window 53, F3

7.a Airborne contamination caused by fire in contaminated solid waste materials accumulated in the facility

S3, F2

\subsection{ACCIDENT ANALYSIS METHODOLOGY}

The radiological consequences of the representative and bounding accidents in the first six hazard and accident categories in Section 4.1 were calculated and compared with the safety classification criteria discussed in Section 2.2.1 to determine the acceptability of the consequences. This required an estimate of the radiological doses at the controlled boundary resulting from the releases caused by the accidents.

\subsubsection{Source Term Development}

The MCO inventory assumed for the analyses is the inventory associated with 270 MKIV fuel assemblies. This is more conservative than assuming an MCO inventory of MKIA fuel assemblies as the MKIV fuel assemblies have a significantly higher source term than the MKIA assemblies.

The estimated maximum quantity of fuel particulate material available in an MCO after fuel washing and racking into the $M C O$ is $16 \mathrm{~kg}(35.3 \mathrm{lb}$ )

(Cowan 1996). In addition, another $0.72 \mathrm{~kg}$ (1.59 1b) of particulate can form from the corrosion oxidation reaction occurring over the period of time between the loading of the SNF at $K$ Basins and completion of cold vacuum drying at the CVDS. For analysis purposes we conservatively assume all of the particulate forms during transport for a maximum MCO particulate content of $16.72 \mathrm{~kg}$ (36.86 1b) per MCO arriving at the CVOS. This particulate material is expected to be the product of chemical and radiochemical reactions of the fuel and cladding, similar in makeup to the sludge found in closed canisters in the $\mathrm{K}$ Basins. The particulate inventory dominates the amount of material released; therefore, for accidents that involve particulate releases, it is the only material considered. For these analyses, the radionuclide inventory for the particulate material is taken to be the same as that for the fuel.

The major radiation exposure pathway for the identified accidents is inhalation of radioactive material. Although there could be dose contributions from the groundshine and submersion pathways, the dose from the other pathways contributes less than $1 \%$ of the total dose for the radionuclides of interest. Therefore, the doses from groundshine and submersion are not included in the radiological dose calculations.

Potential doses from the ingestion pathway are not considered because $D O E$, state, and federal emergency preparedness plans in place 1 imit ingestion of contaminated food in the event of an accident. The primary determinant of 
exposure from the ingestion pathway is the effectiveness of public health measures (i.e., interdiction) rather than the severity of the accident itself. The ingestion pathway, if it occurs, is a relatively slow-to-develop pathway and is not considered an immediate threat to an exposed population in the same sense as the inhalation pathway.

Dose conversion factors in EPA/520/1-88/020, Limiting Values of Radionuclide Intake and Air Concentration and Dose Conversion Factors for Inhalation, Submersion, and Ingestion (EPA 1988), for inhalation for a 50-year dose commitment period have been used to determine the relative contribution of each nuclide to the total composite inhalation dose. The committed EDE for a 50-year dose commitment period is used for the evaluation of radiclogical accident consequences. The dose conversion factors selected for this PSE are consistent with those calculated by the GENII computer code

(Napier et al. 1988). This is the most conservative dose conversion factor library used by GENII.

Isotopes of plutonium and ${ }^{241} \mathrm{Am}$ constitute $99.5 \%$ of the total inhalation dose. The relative contribution from the remaining nuclides is minor in comparison. The doses per unit respirable radioactive material inhaled are given in Table 4-3. The doses are based on data from the safety analysis inventory listed in Table $3-1$ and calculations are referenced in WHC-SD-WM-TI-742, Unit Dose Calculations for the $K$ Basins Safety Regulatory Assessment Feed Basis (Huang 1996). The specific dose for this inventory is $4.3 \times 10^{3} \mathrm{~Sv} / \mathrm{g}\left(4.3 \times 10^{5} \mathrm{rem} / \mathrm{g}\right)$.

Tab7e 4-3. Radiological Analys is of K Basins Fuel - Inhaled Doses.

\begin{tabular}{|c|c|}
\hline Radionuclide & $\begin{array}{c}\text { Committed effective dose } \\
\text { equivaient per unit intake } \\
\text { Sv/g (rem } / g)\end{array}$ \\
\hline${ }^{3} \mathrm{H}$ & $3.3 \mathrm{E}-05(3.3 \mathrm{E}-03)$ \\
\hline${ }^{85} \mathrm{Kr}$ & $3.0 \mathrm{E}-05(3.0 \mathrm{E}-03)$ \\
\hline${ }^{90} \mathrm{Sr}$ & $1.6 \mathrm{E}+01(1.6 \mathrm{E}+03)$ \\
\hline${ }^{90}$ & $7.0 \mathrm{E}-01(7.0 \mathrm{E}+01)$ \\
\hline${ }^{151} \mathrm{Cs}$ & $3.3 \mathrm{E}+00(3.3 \mathrm{E}+02)$ \\
\hline${ }^{238} \mathrm{Pu}$ & $6.7 \mathrm{E}+02(6.7 \mathrm{E}+04)$ \\
\hline${ }^{230} \mathrm{Pu}$ & $7.0 \mathrm{E}+02(7.0 \mathrm{E}+04)$ \\
\hline${ }^{240} \mathrm{Pu}$ & $5.8 \mathrm{E}+02(5.8 \mathrm{E}+04)$ \\
\hline${ }^{241} \mathrm{Pu}$ & $7.6 \mathrm{E}+02(7.6 \mathrm{E}+04)$ \\
\hline${ }^{24} \mathrm{Am}$ & $1.6 \mathrm{E}+03(1.6 \mathrm{E}+05)$ \\
\hline${ }^{244} \mathrm{Cm}$ & $1.4 \mathrm{E}+01(1.4 \mathrm{E}+03)$ \\
\hline Total & $4.3 \mathrm{E}+03(4.3 \mathrm{E}+05)$ \\
\hline
\end{tabular}

Note:

Fuel decayed to January 1, 1995. 


\subsubsection{Dose Calculation}

Radiological inhalation dose consequences for each accident analyzed in this PSE are based on

- Amount of material availabie for release

- Dose conversion factors

- Resuspension or aerosolization rate

- Atmospheric dispersion of the airborne particles

- Duration of exposure

- Breathing rates.

The radiological dose to a maximum individual is typically determined using the following equation:

$$
D=M \times \frac{X}{Q} \times R \times C
$$

where

$$
\begin{aligned}
D & =\text { Dose }(\mathrm{SV}) \\
M & =\text { Quantity of material released }(g \text { or } \mathrm{L}) \\
X / Q= & \text { Time-integrated atmospheric dispersion coefficient }\left(\mathrm{s} / \mathrm{m}^{3}\right) \\
R & =\text { Breathing rate }\left(\mathrm{m}^{3} / \mathrm{s}\right) \\
C & =\text { Dose per unit respirable radioactive material inhaled }(\mathrm{Sv} / \mathrm{g} \\
& \text { or } \mathrm{SV} / \mathrm{L}) .
\end{aligned}
$$

The quantity of respirable material released $(M)$ is determined by the specific accident scenario.

The atmospheric dispersion coefficient $(X / Q)$ is based on specific release conditions (e.g., ground level or elevated, long or short duration) and the receptor's distance from the release. The atmospheric dispersion coefficient is the time-integrated normalized air concentration at the receptor's location. The coefficient represents the dilution of an airborne contaminant caused by atmospheric mixing and turbulence. The $X / Q$ values for the location of the cvDS facility are being represented by X/Q values for the 105-KW Building (Hey 1995). Since the 105-KW Building is slightly closer to the Columbia River than the CVDS facility, the X/Q values for $105-K W$ are slight $7 y$ conservative. The $X / Q$ values used in this report have been generated using the GXO computer program (Hey 1993a and Hey 1993b; see Appendix C). Table 4-4 contains the $X / Q$ values used to determine onsite and offsite consequences. 
Table 4-4. Atmospheric Dispersion Coefficients Used in Accident Analyses for the Cold Vacuum Drying System Facility.

\begin{tabular}{|c|c|c|}
\hline \multirow[b]{2}{*}{ Receptor location description } & \multicolumn{2}{|c|}{$\begin{array}{c}X / Q \\
\text { point source }\left(\mathrm{s} / \mathrm{m}^{3}\right)\end{array}$} \\
\hline & $\begin{array}{l}\text { Without plume } \\
\text { meander, } \\
\text { without stack }\end{array}$ & $\begin{array}{c}\text { With plume } \\
\text { meander, } \\
\text { without stack }\end{array}$ \\
\hline $\begin{array}{l}\text { Onsite } \\
(100 \mathrm{~m} \mathrm{E})\end{array}$ & $7.32 \mathrm{E}-02$ & 1.24 E-02 \\
\hline $\begin{array}{l}\text { Near river bank } \\
(480 \mathrm{~m} \mathrm{NW})\end{array}$ & $2.15 E-03$ & $5.55 E-04$ \\
\hline $\begin{array}{l}\text { Fire station } \\
(4,000 \mathrm{~m} \text { ESE })\end{array}$ & $1.47 \mathrm{E}-04$ & $7.37 \mathrm{E}-05$ \\
\hline $\begin{array}{c}\text { Hanford Site boundary } \\
(12,040 \mathrm{~m} \mathrm{~W})\end{array}$ & $3.58 \mathrm{E}-05$ & $2.60 \mathrm{E}-05$ \\
\hline
\end{tabular}

Values of $X / Q$ were calculated for various distances from the release in the full range of compass directions. For these analyses, the worst-case meteorology (wind speed and direction) for the near river bank, fire station, and for the Hanford Site boundary was used to determine the location where the maximum doses would occur. The same approach was used to determine the direction of the maximum doses at $100 \mathrm{~m}(328 \mathrm{ft})$.

For offsite releases, values of $X / Q$ were calculated for a receptor in the highest dose direction at the Hanford Site boundary, onsite at $100 \mathrm{~m}(328 \mathrm{ft})$ from the facility, at the fire station, and at the near bank of the columbia River. However, for assessment purposes, DOE has directed (Sellers 1996) that the Hanford Site boundary be considered the location of the offsite receptor. Consequences at the near bank of the Columbia River are included for reference only. The maximum onsite receptor for the ground-level release was east of the facility at $100 \mathrm{~m}(328 \mathrm{ft})$, northwest of the facility at $480 \mathrm{~m}(1,575 \mathrm{ft})$ (near river bank), and east-southeast of the facility at $4,000 \mathrm{~m}(13,120 \mathrm{ft})$ (the fire station). The maximum receptor for the Hanford Site boundary $(12,040 \mathrm{~m}[7.5 \mathrm{mi}])$ was west of the facility for the ground-level release.

Correction to the $X / Q$ may be taken for building wake effects if the accident does not change the building configuration. To provide conservatism in the analysis, none of the accidents analyzed in this document use building wake effect corrections. Correction for plume meander is credited for ground releases assumed to occur during neutral or stable atmospheric conditions with wind speeds less than $5 \mathrm{~m} / \mathrm{s}(19.7 \mathrm{ft} / \mathrm{s})$ and with release times greater than 1 hour.

The breathing rate $(R)$ depends on activity factors and exposure duration. A11 accidents analyzed assume 8-hour exposure to the onsite receptor and 24-hour exposure to the offsite receptor. The 8 -hour onsite exposure time is based on a Site shift. Both the 8- and 24-hour exposure times are conservative but appropriate assumptions for the amount of time required to 
WHC-SD-SNF-PSE-003 REV 0

exercise control over an onsite or offsite area. Therefore, the breathing rate used is the acute, light activity rate given in Reference Man:

Anatomical, Physiological, and Metabolic Characteristics (ICRP 1975). Its value is $3.3 \times 10^{-4} \mathrm{~m}^{3} / \mathrm{s}$.

The dose per unit material inhaled (C) is the value for the total committed EDE from Table 4-3.

The protection of facility workers is actively monitored and controlled by WHC Radiation Protection and Emergency Preparedness programs, so dose consequences to facility workers are not calculated in this document. The WHC radiological dose guidelines in WHC-CM-4-45, Section 9.0, 0.005 SV $(0.5 \mathrm{rem})$ offsite and $0.05 \mathrm{SV}(5.0 \mathrm{rem})$ onsite, implement the guidance in DOE Order 6430.1A, Section 1300-1.4, "Guidance on Limiting Exposure to the Public," and are consistent with the graded approach to safety required by DOE Order 5480.23. The WHC radiological dose guidelines are used to evaluate the need for safety-class and safety-significant equipment.

\subsection{ACCIDENT ANALYSIS}

The six hazard and accident categories chosen for evaluation involve release of radioactive materials during various CVDS operations. These include receiving the shipping cask-MCO from $K$ Basins and preparing for shipment of the same to the CSB. The accidents and associated risks are described individually in the following sections. The accidents analyzed include discussion of the safety-class items required for protection of the onsite and offsite receptors.

\subsubsection{Fire}

Scenario Development. MCOs are transported to and from the CVOS using a truck and tractor trailer. An accident involving the tractor could start a fire involving the tractor and tractor fuel. Fires inside the facility involving equipment, process materials, or process waste outside of the MCO may a] so occur.

Source Term Analysis. The source term for the shipping cask-MCO transport system would be a fully loaded MCO with $\mathrm{K}$ Basin water being transported from the $K$ Basins to the CVDS or a dry MCO being transported from the CVDS to the CSB. The source term for a fire inside the facility involving process equipment, process materials, or process waste cannot be determined at this time because of a lack of sufficient design and operational information. However, available information is sufficient to assume any source term for a facility fire outside of the $M C O$ would be bounded by the release associated with the source term present inside the MCO.

Consequence Analysis. Fires involving the shipping cask-MCO transport system will be covered in the Safety Analysis Report for Packaging currently in preparation to be released at a later date. The design basis fire used in the Safety Analysis Report for Packaging is specified as the shipping cask-MCO engulfed in a $30-$ minute, $801.7^{\circ} \mathrm{C}\left(1,475^{\circ} \mathrm{F}\right)$ fire. The criteria state that 
the cask can lose containment as a result of loss of seals during the fire as long as there is no catastrophic loss of contents and no loss of MCO confinement. Therefore, any fire involving the shipping cask-MCO transport system would result in no consequences according to the packaging design criteria.

A facility fire involving process equipment, process materials, or process waste would be bounded by other accident events directly involving the fuel and source term present inside the $\mathrm{MCO}$. Therefore the consequences of these fires are bounded by the flammable gas ignition (Section 4.3.2) and fuel ignition (Section 4.3.5) accident consequences involving the release of the contents of an MCO.

Summary of Safety Class Requirements. There are no additional safetyclass requirements ident ified by fire accident scenarios. The shipping cask-MCO transportation system imposes sufficient fire protection criteria. Fires occurring inside the facility are bounded by accident events involving the contents of an MCO.

\subsubsection{Flammable Gas Ignition}

Scenario Development. Normal operation of the CVDS process calls for initially heating the SNF and the $K$ Basin water in the MCO by circulating heated water through the annulus formed between the outside diameter of the $\mathrm{MCO}$ and the inside diameter of the transportation cask. Heating is continued until a steady-state temperature of $75^{\circ} \mathrm{C}\left(167^{\circ} \mathrm{F}\right)$ is attained. Next, most of the $545 \mathrm{~L}$ (144 gal) of water in the MCO (Transnuclear 1996, Table A3.1-1) is drained out of the MCO, but residual bound water, estimated to be as much as $1.6 \mathrm{~L}(0.42 \mathrm{gal})$, remains in the $\mathrm{MCO}$. The $\mathrm{MCO}$ is then backfilled with a gas mixture of $2 \%$ oxygen in helium. The gas mixture is stored in an outside tank.

The postulated accident scenario begins by assuming that, before purging or backfilling with the gas mixture, there has been a delay in processing. The MCO is allowed to sit unvented long enough for hydrogen to build up in the MCO atmosphere. Hydrogen radicals (represented by $H^{*}$ ) are produced by the exothermic corrosion reaction of water with exposed uranium metal in breached fuel elements.

$$
\mathrm{U}+\mathrm{H}_{2} \mathrm{O} \Rightarrow \mathrm{UO}_{2}+2 \mathrm{H}^{*}
$$

Hydrogen radicals initially formed will immediately combine with oxygen molecules in the helium-oxygen mixture to form water.

$$
2 \mathrm{H}^{*}+\mathrm{O}_{2}=\Rightarrow \mathrm{H}_{2} \mathrm{O}
$$

Dxygen provides a beneficial effect with respect to eliminating hydrogen by preventing the formation of hydrogen molecules. When alt the oxygen is used up, however, the hydrogen radicals will start combining with themselves to form hydrogen molecules.

$$
2 H^{*}=\Rightarrow H_{2}
$$


The hydrogen produced by the uranium-water reaction causes the pressure in the MCO to increase from 1 atm to $5.94 \mathrm{~atm}$. For this preliminary analysis the rate of formation of hydrogen from the uranium corrosion reaction will not be considered.

The analysis assumes that as a result of an incorrect mixture of gas in the tanks, a different gas than the intended purge gas is mistakenly introduced into the $\mathrm{MCO}$. The gas introduced is assumed to be oxygen. The purge is initiated, and a flammable mixture of hydrogen and oxygen results. Injecting oxygen into the MCO increases the pressure from 5.94 atm to $8.23 \mathrm{~atm}$. The most energetic conservative mixture, a stoichiometric mixture (two moles hydrogen per mole of oxygen), is assumed to exist. The composition and quantities of gas in the MCO at this point are shown in Table $4-5$. The volume of gas in the $M C O$ is $0.545 \mathrm{~m}^{3}$.

Table 4-5. Gas Composition and Quantities in Multicanister Overpack before Deflagration.

\begin{tabular}{|c|c|c|c|c|}
\hline Component & Gmoles & $\begin{array}{c}\text { Mole fraction } \\
\left(y_{i}\right)\end{array}$ & $\begin{array}{l}\text { Molecular } \\
\text { weight }(\mathrm{MW})_{\mathrm{i}}\end{array}$ & $(M W)_{;} \times\left(y_{i}\right)$ \\
\hline Hydrogen & 88.89 & 0.5655 & 2.016 & 1.140 \\
\hline Oxygen & 44.45 & 0.2828 & 32.00 & 9.050 \\
\hline Helium & 23.84 & 0.1517 & 4.003 & 0.607 \\
\hline Totals & 157.18 & 1.0000 & -- & 10.797 \\
\hline
\end{tabular}

An ignition source is assumed to exist from various available sources (e.g., metal to metal sparks, static electricity), and the flammable mixture ignites. The ignition leads to a deflagration or combustion that reacts all reactants leading to a potential MCO overpressure event or fuel ignition. The potential fuel ignition event is analyzed in Section 4.3.5. For hydrogen, the minimum energy input required to initiate combustion is very small, $0.03 \mathrm{~mJ}$. For comparison purposes many hydrocarbon gases have a minimum ignition energy of about $0.25 \mathrm{~mJ}$ (Crowl and Louvar 1990). The gas quantities and composition after deflagration would be as found in Table 4-6. It is assumed that all the water formed is in the gaseous state and that complete combustion has taken place. 
Table 4-6. Gas Composition and Quantities after Deflagration.

\begin{tabular}{|l|c|c|c|c|}
\hline \multicolumn{1}{|c|}{ Component } & Gmoles & $\begin{array}{c}\text { Mole } \\
\text { fraction } \\
\left(y_{i}\right)\end{array}$ & $\begin{array}{c}\text { Molecular } \\
\text { weight } \\
(M W)_{i}\end{array}$ & $(M W)_{i}\left(y_{i}\right)$ \\
\hline Hydrogen & 0 & 0 & -- & -- \\
\hline Oxygen & 0 & 0 & -- & -- \\
\hline Water & 88.89 & 0.7885 & 18.02 & 14.21 \\
\hline Helium & 23.84 & 0.2115 & 4.003 & 0.847 \\
\hline \multicolumn{1}{|c|}{ Totals } & 112.73 & $1.0000-$ & -- & 15.05 \\
\hline
\end{tabular}

In an enclosed deflagration, the maximum pressure $\left(p_{m}\right)$ is given by

$$
p_{m}=\frac{p_{1} * M_{1} * T_{2}}{M_{2} * T_{1}} \quad \text { (Thomson 1987) }
$$

where

$p_{1}=$ the initial pressure
$M_{1}=$ the initial molecular weight
$M_{2}=$ the final average molecular weight
$T_{1}=$ the initial temperature $(K)$
$T_{2}=$ the final (adiabatic) temperature $(K)$.

The initial pressure is

$$
p_{q}=8.23 \mathrm{~atm}
$$

and the molecular weights of the gases before and after deflagration are

$$
\begin{aligned}
& M_{1}=10.797 \text { (Table 4-5) } \\
& M_{2}=15.05 \text { (Table 4-6). }
\end{aligned}
$$

A hydrogen deflagration takes place so rapidly that there is not enough time for heat to dissipate. An adiabatic flame temperature is therefore the best estimate of the gas temperature in the MCO. To calculate the adiabatic flame temperature in a constant volume system, the following three equations are used.

$$
\Delta U=u_{p}-u_{R}=0
$$


where

$$
\begin{aligned}
& U=\text { internal energy } \\
& P=\text { products } \\
& R=\text { reactants }
\end{aligned}
$$

and for an adiabatic system the change in internal energy is zero.

$$
\Delta U=\sum\left(n C_{v}\right)_{R}\left(T_{b}-T_{1}\right)+\Delta U_{r}\left(25^{\circ} C\right)+\sum\left(n C_{v}\right)_{P}\left(T_{2}-T_{b}\right)
$$

where

$$
\begin{aligned}
\mathrm{n} & =\text { number of gmoles } \\
\mathrm{C}_{\mathrm{v}} & =\text { integrated mean, constant volume heat capacity (ca)/gmole } \mathrm{K} \text { ) } \\
\Delta \mathrm{U}_{\mathrm{r}}\left(25^{\circ} \mathrm{C}\right) & \left.=\text { internal energy change caused by reaction at } 25^{\circ} \mathrm{C}(\mathrm{ca})\right) \\
\mathrm{T}_{1} & =\text { initial temperature of the gases before reaction }(\mathrm{K}) \\
\mathrm{T}_{2} & =\text { adiabatic reaction temperature }(\mathrm{K}) \\
\mathrm{T}_{\mathrm{b}} & =\text { the base temperature }(\mathrm{K}) \\
\mathrm{T}_{0} & =\text { the heat capacity } \text { base temperature }(273 \mathrm{~K}) . \\
\bar{C}_{v} & =\overline{\mathrm{C}}_{\mathrm{p}}-\mathrm{R} \\
\Delta \mathrm{U}_{\mathrm{r}}= & \Delta \mathrm{H}_{\mathrm{r}}-\mathrm{RT} \Delta \mathrm{N}
\end{aligned}
$$

where

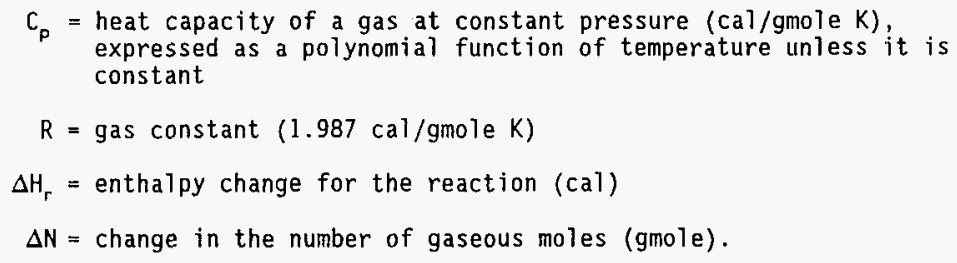


Solving the equation

$$
\sum\left(n C_{v}\right)_{R}\left(T_{b}-T_{1}\right)+\Delta U_{p}\left(25^{\circ} C\right)+\sum\left(n C_{v}\right)_{P}\left(T_{2}-T_{b}\right)=0
$$

for $\mathrm{T}_{2}$ (adiabatic reaction temperature) gives

$$
T_{2}=\frac{\sum\left(n \bar{C}_{v}\right)_{R}\left(T_{1}-T_{b}\right)-\Delta 4}{\sum\left(n \bar{C}_{v}\right)_{p}}+T_{b} .
$$

The calculational approach is to assume a temperature for $T_{2}$ then calculate a temperature. The convergence criterion is that when the absolute value of the assumed temperature less the calculated temperature is less than

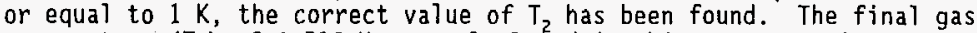
temperature $\left(\mathrm{T}_{2}\right)$ of $4,586 \mathrm{~K}$ was calculated in this manner, using a base temperature of $298 \mathrm{~K}\left(25^{\circ} \mathrm{C}\right)$ and an initial gas temperature $\left(T_{1}\right)$ of $350 \mathrm{~K}$. Finally, a maximum pressure $\left(p_{m}\right)$ of 77.8 atm $(1,143$ psia) was calculated. The ratio of final pressure to initial pressure $\left(p_{\pi} / p_{1}\right)$ is 9.39 . It is likeiy that a pressure vessel (the MCO) will burst without pressure relief if the ratio of $p_{m}$ to $p_{1}$ is greater than four (Thomson 1987).

Determinations of the violence of a closed vessel deflagration are usually characterized in terms of the maximum rate of pressure rise.

Theoretically, this occurs at the end of the explosion when the pressure is at its maximum value. The maximum rate of pressure rise, $891.3 \mathrm{~atm} / \mathrm{s}$, was calculated from the equation

$$
\left(\frac{d P}{d t}\right)_{\max }=\frac{K_{t}}{V^{1 / 3}}
$$

where $K_{G}=728 \mathrm{~atm}^{\star} \mathrm{m} / \mathrm{s}$ for hydrogen (SFPE 1992, Table 2-5.4) and $V=0.545 \mathrm{~m}^{3}$, the $\mathrm{MCO}$ free space volume. The maximum pressure is achieved in 0.078 seconds, calculated by dividing the pressure rise (69.5 atm) by the maximum rate of pressure rise.

The rupture disc on the MCO will be designed to rupture before the 150 psig (11 atm absolute) design pressure of the MCo. The size of the rupture disc opening is not currently known but it was suspected that it would not relieve pressure fast enough to prevent the MCO from failing if the maximum pressure was greater than the MCO failure pressure. Therefore, from the MCO wall thickness $(1.3 \mathrm{~cm}[0.5 \mathrm{in.}])$, material tensile strength (70,000 psi for 304L stainless steel [Perry and Chilton 1973, Table 6-59]) and radius (30.5 cm [12 in.]), the rupture pressure was calculated at 2,846 psig. The maximum pressure caused by the hydrogen deflagration, 1, 143 psia 
(1,128 psig), is less than 2,846 psig by a factor of 2.5. Also, most of the MCO will be inside the shipping cask during processing so the shipping cask may serve as a secondary barrier if the MCO were to rupture.

Source Term Analysis. To estimate the volume of gas released from the $M C O$, assume an isothermal release such that

$$
P_{\text {atm }} V_{\text {atm }}=P_{m} V_{\text {free }}
$$

and

$$
V_{\text {atm }}=\left(P_{m} / P_{a t m}\right) V_{\text {tree }}
$$

where

$$
\begin{aligned}
& \mathrm{P}_{\text {atm }}=\text { atmospheric pressure (1 atm) } \\
& \mathrm{V}_{\text {atm }}=\text { gas volume at l atm pressure } \\
& \mathrm{P}_{\mathrm{m}}^{\mathrm{m}}=\text { the maximum pressure in the MCO }(77.8 \mathrm{~atm}) \\
& \mathrm{V}_{\text {free }}=\text { the free space volume in the MCO }\left(0.545 \mathrm{~m}^{3}\right) .
\end{aligned}
$$

Now subtract $V_{\text {free }}$ from both sides to give the volume of gas released

$$
\begin{aligned}
V_{\text {atm }}-V_{\text {free }} & =\left[\left(P_{\mathrm{m}} / P_{\text {atm }}\right)-1\right] V_{\text {free }} \\
& =[(77.8 / 1)-1]\left(0.545 \mathrm{~m}^{3}\right) \\
& =41.9 \mathrm{~m}^{3} .
\end{aligned}
$$

The gas will consist of steam, helium, and radioactive particulate matter that is aerodynamically entrained by the explosion. The hot gas will rise and cool as it mixes with air in the CVDS processing bay, but no credit is taken for the processing bay as a barrier to the release of particulates. The maximum possible quantity of particulates released from a failed MCO is the total inventory of particulates in the MCO, 16.72 kg (36.86 lb) (Cowan 1996).

Based on venting of pressurized $\mathrm{UO}_{2}$ powders, an airborne release fraction (ARF) of 0.06 and a respirable fraction (RF) of 0.42 are used. These fractions are obtained from Table 4-12 of DOE-HDBK-3010-94, Airborne Release Fractions/Rates and Respirable Fractions/Rates for Nonreactor Nuclear Facilities (Mishima 1994).

The released source term is that quantity of contamination released from the MCO during the accident sequence. With the maximum particulate loading of $16.72 \mathrm{~kg}(36.86 \mathrm{lb})$ per MCO on arrival at the CVDS, the estimated inventory released is

$$
(0.06)(0.42)(16.72 \mathrm{~kg})=0.42 \mathrm{~kg} \text {. }
$$


Consequence Analysis. The released source term is used to determine the radiological doses to the onsite and offsite receptors. The following assumptions have been used to determine radiological consequences to human receptors.

- The release is caused by pressure in the MCO that ruptures the MCO and exposes the contents of the MCO to release under pressure.

- Only short-term exposure effects resulting from inhalation are evaluated.

- The values of $X / Q$ for the selected receptor location are those given in Table 4-4 for ground-7evel releases without plume meander.

- The dose per unit of respirable radioactive material inhaled is the total given in Table $4-3\left(4.3 \times 10^{3} \mathrm{~Sv} / \mathrm{g}\left[4.3 \times 10^{5} \mathrm{rem} / \mathrm{g}\right]\right)$.

The unmitigated EDE for the onsite receptor that results from the depressurization of an MCO can be calculated using the equation in Section 4.2.2.

$$
\begin{aligned}
D & =M \times \frac{\chi}{Q} \times R \times C \\
& =(0.42 \mathrm{~kg})\left(1,000 \frac{\mathrm{g}}{\mathrm{kg}}\right)\left(7.32 \times 10^{-2} \frac{\mathrm{s}}{\mathrm{m}^{3}}\right)\left(3.3 \times 10^{-4} \frac{\mathrm{m}^{3}}{\mathrm{~s}}\right)\left(4.3 \times 10^{3} \frac{\mathrm{Sv}}{\mathrm{g}}\right) \\
& =43.6 \mathrm{SV}(4,360 \mathrm{rem}) .
\end{aligned}
$$

Dose consequences calculated in the same manner for other selected receptors are given in the Table 4-7.

Summary of Safety $\mathrm{Cl}$ ass Requirements. If this accident is not mitigated or prevented by designed safety features, the radiological dose consequence to the onsite receptor $100 \mathrm{~m}(328 \mathrm{ft})$ east of the facility is $43.6 \mathrm{SV}$ $(4,360 \mathrm{rem})$. The dose to the offsite receptor at the near river bank $480 \mathrm{~m}$ $(1,575 \mathrm{ft})$ northwest of the facility is $1.28 \mathrm{~Sv}(128 \mathrm{rem})$. The dose at the fire station $4,000 \mathrm{~m}(13,120 \mathrm{ft})$ east southeast of the facility is $8.76 \mathrm{SV}$ (8.76 rem). The dose at the Hanford Site boundary is 2.13 E-02 Sv (2.13 rem). These doses exceed those permitted by WHC guidelines (WHC-CM-4-46). This mandates mitigative or preventive design features designated safety class. To meet the consequence guidelines, the release from the facility needs to be further reduced. This could be done with systems that eliminate the possibility of introducing unwanted oxygen into the MCO. These systems would be designated safety class. Aiso, a safety-class building confinement system should be considered. 
Table 4-7. Calculated Dose Consequences for Multicanister Overpack Flammable Gas Ignition.

\begin{tabular}{|c|c|c|c|}
\hline \multirow{2}{*}{ Receptor location } & \multicolumn{2}{|c|}{$\begin{array}{c}\text { Unmitigated release } \\
\text { (point source, without stack or } \\
\text { plume meander) }\end{array}$} & \multirow{2}{*}{$\begin{array}{l}\text { Guidelines } \\
\text { Sv (rem) }\end{array}$} \\
\hline & $\begin{array}{l}X / Q \\
\mathrm{~s} / \mathrm{m}^{3}\end{array}$ & $S v \stackrel{E D E}{(\text { rem) }}$ & \\
\hline $\begin{array}{l}\text { Onsite } \\
(100 \mathrm{~m} \mathrm{E})\end{array}$ & $7.32 \mathrm{E}-02$ & $\begin{array}{c}43.6 \\
(4,360 \text { rem })\end{array}$ & $\begin{array}{cc}5.0 & \varepsilon-02 \\
(5.0 & \text { rem })\end{array}$ \\
\hline $\begin{array}{l}\text { Near river bank } \\
(480 \mathrm{~m} \mathrm{NW})\end{array}$ & $2.15 E-03$ & $\begin{array}{c}1.28 \\
(128 \mathrm{rem})\end{array}$ & -- \\
\hline $\begin{array}{l}\text { Fire station } \\
(4,000 \mathrm{~m} \text { ESE })\end{array}$ & $1.47 \mathrm{E}-04$ & $\begin{array}{l}8.76 \text { E-02 } \\
(8.76 \text { rem })\end{array}$ & -- \\
\hline $\begin{array}{c}\text { Hanford Site boundary } \\
(12,040 \mathrm{~m} \mathrm{~W})\end{array}$ & 3.58 E-05 & $\begin{array}{r}2.13 \mathrm{E}-02 \\
(2.13 \mathrm{rem})\end{array}$ & $\begin{array}{l}5.0 \mathrm{E}-03 \\
(0.5 \text { rem })\end{array}$ \\
\hline
\end{tabular}

Notes:

Guidel ines are from HHC-CM-4-46, Nonreactor Facility Safety Analysis Manual, West inghouse Hanford Company, Richland, Washington.

$E O E=$ effective dose equivalent.

\subsubsection{Multicanister Overpack Overpressurization}

Scenario Development. MCOs arrive at the CVDS facility sealed with $K$ Basin water in the shipping cask annulus and in the MCO with a slight volume of gas in the MCO headspace. The casks are prepared, opened, and the rupture disk cap removed prior to cold vacuum start. There is a potential for accumulation of hydrogen as a result of radiolytic or chemical reactions of water with the fuel during shipping. Operator failure or equipment failure could also result in MCO overpressurization. The excessive pressure from either hydrogen generation or overpressurization during operations may rupture the rupture disk with potential releases of solids.

The design pressure of the MCO is $1.0 \mathrm{MPa}$ gauge (150 psig), so the rupture disk will be designed to rupture at some pressure lower than this. A ruptured disk would allow particulate from the MCO to vent into the CVDS bay area and in turn into the environment.

Source Term Analysis. Information and assumptions used to determine the amount of material released are as follows.

- The bounding particulate inventory at risk in the MCO is estimated in WHC-SO-SNF-TI-023, Bounding Particulate Contents of a

Multicanister Overpack (Cowan 1996). The total inventory is

$16.72 \mathrm{~kg}(36.86 \mathrm{lb})$ of particulate material in the MCO on arrival at the CVDS available for release. 
- The ARF of $6.0 \times 10^{-2}$, with an RF of 0.42 , is based on the value for venting of pressurized $\mathrm{UO}_{2}$ powders at $1.7 \mathrm{MPa}$ gauge $(250 \mathrm{psig})$ in Table 4-12 of DOE-HDBK-3010-94 (Mishima 1994). DOE-HDBK-3010-94 does not provide an ARF for $1.0 \mathrm{MPa}$ gauge (150 psig) so the $1.7 \mathrm{MPa}$ gauge (250 psig) ARF is used as a conservative estimate since the larger pressurized release would yield a larger ARF.

The released source term is that quantity of contamination released from the MCO during the accident sequence. With the maximum particulate loading of $16.72 \mathrm{~kg}(36.86 \mathrm{lb})$ per MCO on arrival at the CVDS, the estimated inventory released is

$$
\left(6.0 \times 10^{-2}\right)(0.42)(16.72 \mathrm{~kg})=0.42 \mathrm{~kg} .
$$

Consequence Analysis. The released source term is used to determine the radiological doses to the onsite and offsite receptors. The following assumptions have been used to determine radiological consequences to human receptors.

- The release is caused by pressure in the MCO causing the rupture disk to rupture and expose the contents of the MCO to release under pressure.

- Only short-term exposure effects resulting from inhalation are evaluated.

- The vaiues of $X / Q$ for the selected receptor location are those given in Table 4-4 for ground-level releases without plume meander.

- The dose per unit of respirable radioactive material inhaled is the total given in Table $4-3\left(4.3 \times 10^{3} \mathrm{~Sv} / \mathrm{g}\left[4.3 \times 10^{5} \mathrm{rem} / \mathrm{g}\right]\right)$.

The unmitigated EDE for the onsite receptor that results from the depressurization of an MCO can be calculated using the equation in Section 4.2.2.

$$
\begin{aligned}
D & =M \times \frac{X}{Q} \times R \times C \\
& =(0.42 \mathrm{~kg})(1,000 \mathrm{~g} / \mathrm{kg})\left(7.32 \times 10^{-2} \frac{\mathrm{s}}{\mathrm{m}^{3}}\right)\left(3.3 \times 10^{-4} \frac{\mathrm{m}^{3}}{\mathrm{~s}}\right)\left(4.3 \times 10^{3} \frac{\mathrm{sv}}{\mathrm{g}}\right) \\
& =43.6 \mathrm{SV}(4,360 \mathrm{rem}) .
\end{aligned}
$$

Dose consequences calculated in the same manner for other selected receptors are given in the Table 4-8. 
Table 4-8. Calculated Dose Consequences for Multicanister Overpack Overpressurization.

\begin{tabular}{|c|c|c|c|}
\hline \multirow{2}{*}{ Receptor location } & \multicolumn{2}{|c|}{$\begin{array}{c}\text { Unmitigated release } \\
\text { (point source, without stack or } \\
\text { plume meander) }\end{array}$} & \multirow{2}{*}{$\begin{array}{l}\text { Guidelines } \\
\text { Sv (rem) }\end{array}$} \\
\hline & $\begin{array}{l}X / 0^{3} \\
\mathrm{~s} / \mathrm{m}^{3}\end{array}$ & Sv $\stackrel{\text { EDE }}{\text { (rem) }}$ & \\
\hline $\begin{array}{c}\text { Onsite } \\
(100 \mathrm{~m} \mathrm{E})\end{array}$ & $7.32 \quad E-02$ & $\begin{array}{c}43.6 \\
(4,360 \text { rem })\end{array}$ & $\begin{array}{l}5.0 \mathrm{E}-02 \\
(5.0 \mathrm{rem})\end{array}$ \\
\hline $\begin{array}{c}\text { Near river bank } \\
(480 \mathrm{~m} \mathrm{NW})\end{array}$ & $2.15 \mathrm{E}-03$ & $\begin{array}{c}1.28 \\
(128 \mathrm{rem})\end{array}$ & -- \\
\hline $\begin{array}{l}\text { Fire station } \\
(4,000 \mathrm{~m} \text { ESE })\end{array}$ & $1.47 \mathrm{E}-04$ & $\begin{array}{c}8.76 \text { E-02 } \\
(8.76 \text { rem })\end{array}$ & $\begin{array}{l}5.0 \mathrm{E}-02 \\
(4.0 \mathrm{rem})\end{array}$ \\
\hline $\begin{array}{l}\text { Hanford Site boundary } \\
(12,040 \mathrm{~m} \mathrm{~W})\end{array}$ & $3.58 \mathrm{E}-05$ & $\begin{array}{r}2.13 \text { E-02 } \\
(2.13 \text { rem })\end{array}$ & $\begin{array}{l}5.0 \mathrm{E}-03 \\
(0.5 \mathrm{rem})\end{array}$ \\
\hline
\end{tabular}

Notes:

Guidelines are from WHC-CM-4-46, Nonreactor Facility Safety Analys is Manual, West inghouse Hanford Compeny, Richland, Washington.

$E D E$ = effective dose equivalent.

Summary of Safety Class Requirements. If this accident is not mitigated or prevented by designed safety features, the radiological dose consequence to the onsite receptor $100 \mathrm{~m}(328 \mathrm{ft})$ east of the facility is $43.6 \mathrm{SV}$ $(4,360 \mathrm{rem})$. The dose to the offsite receptor at the near river bank $480 \mathrm{~m}$ $(1,575 \mathrm{ft})$ northwest of the facility is $1.28 \mathrm{~Sv}(128 \mathrm{rem})$. The dose at the fire station $4,000 \mathrm{~m}$ east-southeast of the facility is $8.76 \times 10^{-2} \mathrm{SV}(8.76$ rem). The dose at the Hanford Site boundary is $2.13 \times 10^{-2} \mathrm{~Sv}(2.13 \mathrm{rem})$. These doses exceed those permitted by WHC guidelines (WHC-CM-4-46). This mandates mitigative or preventive design features designated safety class.

To meet the consequence guidelines, the release from the facility needs to be further reduced. This could be done with a building confinement system. This system would be designated safety class. Systems that would contain the release closer to the source could be used as an alternative. This would require a safety-class filtered ventilation hood in the bay area to contain releases when the cask $l i d$ is removed and when the flanges are removed from the filter housing and the rupture disk. During cold vacuum operation after the MCO rupture disk cap is removed, the $M C O$ and cold vacuum system, including the ventilation hood, and/or building confinement system, would be designated safety class for confinement of releases. 


\subsubsection{Multicanister Overpack Mechanical Damage}

Scenario Development. MCOs arrive at the CVDS facility sealed with $K$ Basin water in the cask annulus and in the MCO with a slight volume of gas in the MCO headspace. There is a potential for overpressurization from accumulation of hydrogen resulting from radiolytic or chemical reactions of residual water with the fuel to cause mechanical damage to the MCO. This damage could occur during receiving and handling of the cask-Mco before the cask is opened and the rupture disk cap being removed or after cold vacuum drying when the rupture disk is capped for shipment to the CSB. Operator failure or equipment failure during handling could also result in MCO mechanical damage. The excessive mechanical damage from either hydrogen generation, overpressurization, or handling with the rupture disk and high-efficiency particulate air filter capped may cause rupture of the MCO with potential releases of solids.

The design pressure of the $M C O$ is $1.0 \mathrm{MPa}$ gauge ( $150 \mathrm{psig}$ ), so the rupture disk will be designed to rupture at some pressure lower than the design pressure and the cask will rupture at some pressure greater than the design pressure. A ruptured $\mathrm{MCO}$ in an unsealed shipping cask would allow particulate from the MCO to vent into the CVDS bay area and, in turn, into the environment.

This event is the same as the MCO overpressurization release accident of Section 4.3.3 except the release is through a ruptured MCO with the rupture disk and high-efficiency particulate air filter capped instead of releasing through the rupture disk. Although the failure pressure for this event will be greater than 1.0 MPa gauge (150 psig) for the rupture disk, it is assumed to be less than $1.7 \mathrm{MPa}$ gauge (250 psig). Therefore, the same consequence analysis used in Section 4.3 .3 is used here. There are no differences in the assumptions, calculations, and results.

Source Term Analysis. Information and assumptions used to determine the amount of material released are as follows.

- The bounding particulate inventory at risk in the MCO is estimated in WHC-SD-SNF-TI-023 (Cowan 1996). The total inventory is $16.72 \mathrm{~kg}$ $(36.86 \mathrm{lb})$ of particulate material in the MCO on arrival at the CVDS available for release.

- The ARF of $6.0 \times 10^{-2}$, with an RF of 0.42 , is based on the value for venting of pressurized $\mathrm{UO}_{2}$ powders at $1.7 \mathrm{MPa}$ gauge (250 psig) in Table 4-12 of DOE-HDBK-3010-94 (Mishima 1994). If the release is at a pressure greater than 1.7 MPa gauge $(250 \mathrm{psig})$, then the ARF could be as large as $1.0 \times 10^{-1}$ with an RF of 0.7 , which would make this analysis nonconservative. However, it is judged that the ARF and RF used here are adequately conservative. 
The released source term is that quantity of contamination released from the MCO during the accident sequence. With the maximum particulate loading of $16.72 \mathrm{~kg}(36.86 \mathrm{lb})$ per MCO on arrival at the CVDS, the estimated inventory released is

$$
\left(6.0 \times 10^{-2}\right)(0.42)(16.72 \mathrm{~kg})=0.42 \mathrm{~kg} .
$$

Consequence Analysis. The released source term is used to determine the radiological doses to the onsite and offsite receptors. The following assumptions have been used to determine radiological consequences to human receptors.

- The release is caused by pressure in the MCO that ruptures the MCO and exposes the contents of the MCO to release under pressure.

- Only short-term exposure effects resulting from inhalation are evaluated.

- The values of $X / Q$ for the selected receptor location are those given in Table 4-4 for ground-level releases without plume meander.

- The dose per unit of respirable radioactive materia] inhaled is the total given in Table $4-3\left(4.3 \times 10^{3} \mathrm{~Sv} / \mathrm{g}\left[4.3 \times 10^{5} \mathrm{rem} / \mathrm{g}\right]\right)$.

The unmitigated EDE for the onsite receptor that results from the depressurization of an $\mathrm{MCO}$ can be calculated using the equation in Section 4.2.2.

$$
\begin{aligned}
D & =M \times \frac{X}{Q} \times R \times C \\
& =\langle 0.42 \mathrm{~kg}\rangle\left\langle(1,000 \mathrm{~g} / \mathrm{kg})\left(7.32 \times 10^{-2} \frac{\mathrm{s}}{\mathrm{m}^{3}}\right)\left(3.3 \times 10^{-4} \frac{\mathrm{m}^{3}}{\mathrm{~s}}\right)\left(4.3 \times 10^{3} \frac{\mathrm{Sv}}{\mathrm{g}}\right)\right. \\
& =43.6 \mathrm{SV}(4,360 \mathrm{rem}) .
\end{aligned}
$$

Dose consequences calculated in the same manner for other selected receptors are given in the Table 4-9.

Sumary of Safety Class Requirements. If this accident is not mitigated or prevented by designed safety features, the radiological dose consequence to the onsite receptor $100 \mathrm{~m}(328 \mathrm{ft})$ east of the facility is $43.6 \mathrm{SV}(4,360 \mathrm{rem})$. The dose to the offsite receptor at the near river bank $480 \mathrm{~m}(1,575 \mathrm{ft})$ northwest of the facility is $1.28 \mathrm{~Sv}$ (128 rem). The dose at the fire station $4,000 \mathrm{~m}$ east-southeast of the facility is $8.76 \times 10^{-2} \mathrm{~Sv}(8.75 \mathrm{rem})$. The dose at the Hanford Site boundary is $2.13 \times 10^{-2}$ Sv $(2.13$ rem). These doses exceed those permitted by WHC guidelines (WHC-CM-4-46). This mandates mitigative or preventive design features designated safety class. 
Table 4-9. Calculated Dose Consequences for Multicanister Overpack Mechanical Damage.

\begin{tabular}{|c|c|c|c|}
\hline \multirow{2}{*}{ Receptor location } & $\begin{array}{c}\text { Unmitigated release } \\
\text { (point source, without stack or } \\
\text { plume meander) }\end{array}$ & $\begin{array}{c}\text { Guidelines } \\
\text { Sv (rem) }\end{array}$ \\
\cline { 2 - 4 } & $\begin{array}{c}\mathrm{X} / 0 \\
\mathrm{~s} / \mathrm{m}^{3}\end{array}$ & $\begin{array}{c}\mathrm{EDE} \\
\text { Sv (rem) }\end{array}$ & \\
\hline $\begin{array}{c}\text { Onsite } \\
(100 \mathrm{~m} \mathrm{E})\end{array}$ & $7.32 \mathrm{E}-02$ & $\begin{array}{c}43.6 \\
(4,360 \mathrm{rem})\end{array}$ & $\begin{array}{c}5.0 \mathrm{E}-02 \\
(5.0 \mathrm{rem})\end{array}$ \\
\hline $\begin{array}{c}\text { Near river bank } \\
(480 \mathrm{~m} \mathrm{NW})\end{array}$ & $2.15 \mathrm{E}-03$ & $\begin{array}{c}1.28 \\
(128 \mathrm{rem})\end{array}$ & - \\
\hline $\begin{array}{c}\text { Fire station } \\
(4,000 \mathrm{~m} \text { ESE) }\end{array}$ & $1.47 \mathrm{E}-04$ & $\begin{array}{c}8.76 \mathrm{E}-02 \\
(8.76 \mathrm{rem})\end{array}$ & $\begin{array}{c}5.0 \mathrm{E}-02 \\
(5.0 \mathrm{rem})\end{array}$ \\
\hline $\begin{array}{c}\text { Hanford Site boundary } \\
(12,040 \mathrm{~mW})\end{array}$ & $3.58 \mathrm{E}-05$ & $\begin{array}{c}2.13 \mathrm{E}-02 \\
(2.13 \mathrm{rem})\end{array}$ & $\begin{array}{c}5.0 \mathrm{E}-03 \\
(0.5 \mathrm{rem})\end{array}$ \\
\hline
\end{tabular}

Notes:

Guidel ines are fron WHC-CM-4-46, Nonreactor Facility Safety Analysis Manual, Westinghouse Hanfard Company, Richland, Hashington.

EOE = effective dose equivalent.

To meet the consequence guidelines, the release from the facility needs to be further reduced. This could be done with a building confinement system that would be functional when the cask is unsealed inside the CVDS bay. This system would be designated safety class.

\subsubsection{Fuel Ignition}

An MCO exits the cold vacuum drying process with $1.8 \mathrm{~kg}$ (4 1b) of residual water. Because of a combination of the corrosion reaction exotherm and the radiolytic decay exotherm, the temperature of the MCO contents is at $275{ }^{\circ} \mathrm{C}\left(527^{\circ} \mathrm{F}\right)$, the lower ignition temperature for corroded or irradiated fuel. Uncontrolled oxygen incursion into an MCO subsequent to the cold vacuum drying process results in an uncontrolled exothermic reaction (combustion) in the MCO with the loss of MCO containment.

Scenario Development. An MCO containing 270 irradiated fuel elements and sludge is in the staging process prior to being transported to the CSB. The temperature of the $M C O$ contents has reached $275^{\circ} \mathrm{C}\left(527{ }^{\circ} \mathrm{F}\right)$ as a result of the combined exotherms from corrosion and radiolytic decay. The integrity of the $\mathrm{MCO}$ is lost by some means (e.g., pressurization caused by hydrogen generation and release of the rupture disk). The $M C O$ fills with air. The reaction becomes self-sustaining, and the fuel in the MCO oxidizes with the potential for release of radioactive oxide particulate materials from the reaction. The reaction continues until complete failure of the MCO causes complete oxidation of all the remaining fuel. This scenario is assumed to be the bounding unmitigated accident. 
Source Term Analysis. An accident-release quantity determination established the amount of contamination released from the facility (the released source term). Information and assumptions used to determine the amount of material released are as follows.

- The MCO contains a maximum of 270 fuel assemblies.

- The ARF $\times$ RF for uranium with complete oxidation of the metal with an airflow of 0 to $2 \mathrm{~m} / \mathrm{s}(0$ to $7 \mathrm{ft} / \mathrm{s})$ and temperature greater than $500^{\circ} \mathrm{C}\left(932^{\circ} \mathrm{F}\right.$ ) is $1.0^{\circ} \times 10^{-3}$ (Mishima 1994).

- An ARF x RF value of 0.09 (Mishima 1994) is to be used in calculating the dose consequence contribution for ${ }^{137} \mathrm{Cs}$.

The released source term is that quantity of contamination released from the MCO during the accident sequence. The inventory at risk from the fuel is determined by assuming that the entire contents of the MCO (270 assemblies) is involved in release of the radioactive material. The maximum fuel inventory in an MKIV fuel assembly is $23.43 \mathrm{~kg}$. The maximum fuel inventory in an MCO is $6.33 \times 10^{3} \mathrm{~kg}\left(1.39 \times 10^{4} \mathrm{1b}\right)$. This yields an inventory at risk from the complete oxidation of the fuel elements of $5.3 \mathrm{~kg}$.

Inventory at risk

$$
\left(1.0 \times 10^{-3}\right)(270)(23.43 \mathrm{~kg})=6.3 \mathrm{~kg} \text {. }
$$

Cesium-137 volatilizes to a much greater extent. In the dose calculation, the dose consequences from cesium were evaluated separately and added to those calculated for the fuel. Since the mass contribution of ${ }^{137} \mathrm{Cs}$ is insignificant compared to the bulk of the fuel, the fuel inventory was not corrected for cesium.

Consequence Analysis. Using the released source term, the radiological doses to the onsite and offsite receptors were determined. The following assumptions were used to determine radiological consequences to human receptors.

- The offsite individual at the near river bank is located $480 \mathrm{~m}$ $(1,575 \mathrm{ft})$ northwest of the release point. The receptor at the Hanford Site boundary is located $12,040 \mathrm{~m}$ ( $7.5 \mathrm{mi}$ ) west. The maximum onsite individual is 10 cated $100 \mathrm{~m}$ (328 ft) east of the release point.

- Only short-term exposure effects, inhalation, and submersion, are to be evaluated.

- The ${ }^{239} \mathrm{Pu}$ is in the oxide form for these calculations, and the release is caused by high temperature.

- The values of $X / Q$ for the selected receptor locations are from Table 4-4 for ground-level releases without plume meander. 
- The dose per unit of respirable radioactive material inhaled is $4.3 \times 10^{3} \mathrm{~Sv} / \mathrm{g}\left(4.3 \times 10^{5} \mathrm{rem} / \mathrm{g}\right)$ from Table $4-3$.

- The value of $3.33 \mathrm{~Sv} \mathrm{Cs/g} \mathrm{U}$ is obtained from analytical data sheets (Huang 1996).

The unit doses and atmospheric dispersion coefficients provided in Tables 4-3 and 4-4 are used to determine the EDE resulting from the loss of the contents of the MCO. The unmitigated EDE for the onsite receptor can be calculated using the equation in Section 4.2.2.

$$
\begin{aligned}
D & =M \times \frac{\chi}{Q} \times R \times C \\
& =(6.3 \mathrm{~kg})(1000 \mathrm{~g} / \mathrm{kg})\left(7.32 \times 10^{-2} \frac{\mathrm{s}}{\mathrm{m}^{3}}\right)\left(3.3 \times 10^{-4} \frac{\mathrm{m}^{3}}{\mathrm{~s}}\right)\left(4.3 \times 10^{3} \frac{\mathrm{Sv}}{\mathrm{g}}\right) \\
& =657 \mathrm{SV}(65,700 \mathrm{rem}) .
\end{aligned}
$$

Evaluating the dose consequences from ${ }^{137} \mathrm{Cs}$ for the onsite receptor

$$
\begin{aligned}
\text { Dose }=(3.33 \mathrm{SVCS} / \mathrm{gU}) \times(0.09) & \times\left(6.33 \times 10^{6} \mathrm{gU}\right) \times\left(3.3 \times 10^{-4} \frac{\mathrm{m}^{3}}{\mathrm{~s}}\right) \times\left(7.32 \times 10^{-2} \mathrm{~s} / \mathrm{m}^{3}\right. \\
& =45.8 \mathrm{SV}(4,580 \mathrm{rem}) .
\end{aligned}
$$

The cumulative dose consequences for the ignited fuel event for the onsite receptor then is

$$
\begin{aligned}
\text { Total dose } & =\text { dose } U+\text { dose } 137 \mathrm{Cs} \\
& =657 \mathrm{SV}+45.8 \mathrm{SV}=703 \mathrm{~Sv}(70,300 \mathrm{rem})
\end{aligned}
$$

Dose consequences calculated in the same manner for other selected receptors are given in Table 4-10. 
Table 4-10. Summary of Calculated Dose Consequences for Fue 1 Ignition.

\begin{tabular}{|c|c|c|c|}
\hline \multirow{2}{*}{ Receptor location } & \multicolumn{2}{|c|}{$\begin{array}{l}\text { Unmitigated } \\
\text { (point source, unfiltered } \\
\text { ground release) }\end{array}$} & \multirow{2}{*}{$\begin{array}{l}\text { Guidelines } \\
\text { Sv (rem) }\end{array}$} \\
\hline & $\begin{array}{l}X / Q \\
\mathrm{~s} / \mathrm{m}^{3}\end{array}$ & $S v \stackrel{\text { EDE }}{(r e m)}$ & \\
\hline $\begin{array}{l}\text { Onsite } \\
(100 \mathrm{~m} \mathrm{E})\end{array}$ & 7.32 E-02 & $\begin{array}{c}702.8 \\
(70,280 \mathrm{rem})\end{array}$ & $\begin{array}{l}5.0 \mathrm{E}-0.2 \\
(5.0 \text { reIn) }\end{array}$ \\
\hline $\begin{array}{l}\text { Near river bank } \\
(480 \mathrm{~m} \mathrm{NW})\end{array}$ & $2.15 \mathrm{E}-03$ & $\begin{array}{c}20.64 \\
(2,064 \text { rem })\end{array}$ & -- \\
\hline $\begin{array}{l}\text { Fire station } \\
(4,000 \mathrm{~m} \text { ESE })\end{array}$ & $1.47 \mathrm{E}-04$ & $\begin{array}{c}1.40 \\
(140 \mathrm{rem})\end{array}$ & $\begin{array}{c}5.0 \mathrm{E}-012 \\
(5.0 \text { rein })\end{array}$ \\
\hline $\begin{array}{l}\text { Hanford Site boundary } \\
\qquad(12,040 \mathrm{~m} \mathrm{~W})\end{array}$ & $3.58 \mathrm{E}-05$ & $\begin{array}{c}0.34 \\
(34 \text { rem })\end{array}$ & $\begin{array}{l}5.0 \text { E-0.3 } \\
(0.5 \text { reIn })\end{array}$ \\
\hline
\end{tabular}

Note:

Guidel ines are from HHC-CM-4-46, Nonreactor Facility Safety Analys is Manual, Westinghouse Hanford Company, Richland, Washington.

$E D E=\varepsilon f$ fective dose equivalent.

Comparison to Guidelines. The potential unmitigated doses to the onsite (nonfacility) worker were calculated to be $702.8 \mathrm{~Sv}(70,280 \mathrm{rem})$ EDE at $100 \mathrm{~m}$ $(328 \mathrm{ft}$ ) and $1.40 \mathrm{SV}(140 \mathrm{rem})$ EDE at the fire station $4,000 \mathrm{~m}(13,120 \mathrm{ft})$ east southeast of the CVDs. The offsite doses were calculated to be $20.64 \mathrm{~Sv}$ $(2,064$ rem) and $0.34 \mathrm{~Sv}$ (34 rem) EDE at the near river bank and Hanford Site boundary respectively. The overall risk exceeds the guidelines given in WHC-CM-4-46.

Summary of Safety Class Equipment. The unmitigated offsite dose consequence potentialiy exceeds $5.0 \times 10^{-3}$ SV $(0.5$ rem) EDE and therefore requires safety-class design features to prevent or mitigate the dose to within the guidelines.

\subsubsection{Liquid Releases}

Scenario Development. The primary function of the liquid handling system is to provide a local point of collection for process liquids in each of the six process bays. Liquids will be pumped from the liquid handling system in each CVDS bay to an $18,900 \mathrm{~L}(5,000 \mathrm{gal})$ central liquid holding tank. The Jiquid in the central holding tank will be transported by tanker truck for disposition. A breach of this liquid handling system could result in spilling or spraying this water inside the CVOS building.

- Spill Accidents. Spill accidents potentially involve release of radionuclides from free fall of the liquid to a collection area and then from evaporation of the liquid. The building ventilation, or 
natural circulation, entrains aerosols from the spill, potentially carrying contamination outside the facility. Some of the water from large spills (such as $18,900 \mathrm{~L}$ [5,000 gall]) in the CVDS is expected to run into floor drains into a holding tank, which would prevent the airborne release of radionuclides from that water collected in the holding tank.

- Spray Accidents. If the holding tank line (pipes or hoses) carrying the MCO water, under pressure, from the pump to the tank truck is breached (e.g., hose coupling not properly fitted), the water can escape in a variety of ways. Breaches venting pressurized liquids can range from pinhole leaks in pipes (generating a mist) to drips from very slow leaks to large jets of liquids that may gush from large holes. The amount and aerodynamic size distribution of the spray generated are a function of the size and characteristics of the breach, the upstream pressure, and the liquid characteristics (e.g., viscosity, density, volatility).

Intuitively, the maximum ARF from the liquid release category of accidents would be generated by a pinhole leak in the pressurized line spraying a mist into the air. Source terms will be analyzed for both situations to demonstrate which is limiting.

Source Term Analysis. For the spill case, the inventory at risk for the liquid release category of accidents is $18,900 \mathrm{~L}(5,000 \mathrm{ga}$ ) of MCO water, which is assumed to be in the main holding tank. It is conservatively assumed that all 18,900 L $(5,000 \mathrm{gal})$ is involved in a spill accident. For the spill case the three components to the source term are (1) release from the free fall of water, (2) release from resuspension from the pool, and (3) release from evaporation from the pool of water that forms following the spill. For a free-fall spill of aqueous solutions with a $3-\mathrm{m}(10-\mathrm{ft})$ fall distance, the upper bound for an ARF is $2.0 \times 10^{-4}$ with an RF of 0.5 (Mishima 1994). The total respirable airborne fraction is

$$
\left(2.0 \times 10^{-6}\right)(0.5)=1.0 \times 10^{-4} \text {. }
$$

The respirable release source term from the free fall of the liquid is

$$
(5,000 \mathrm{gal})(3.7854 \mathrm{~L} / \mathrm{gal})\left(1.0 \times 10^{-4}\right)=1.89 \mathrm{~L} \text {. }
$$

With respect to resuspension, DOE-HDBK-3010-94, Section 3.1

(Mishima 1994), shows that for aerodynamic entrainment and resuspension indoors, on a heterogeneous surface (stainless steel, concrete), and with low airspeeds up to normal facility ventilation flows, a bounding airborne release rate is $4.0 \times 10^{-7}$ per hour. Conservatively assuming a 24 -hour accident time period and an $\mathrm{RF}$ of 1.0 , the total respirable airborne fraction is

$$
\left(4.0 \times 10^{-7} / \mathrm{h}\right)(1.0)(24 \mathrm{~h})=9.6 \times 10^{-6} \text {. }
$$

The respirable release source term from resuspension is

$$
(5,000 \mathrm{gal})(3.7854 \mathrm{~L} / \mathrm{gal})\left(9.6 \times 10^{-6}\right)=0.18 \mathrm{~L} \text {. }
$$


With respect to evaporation, DOE-HDBK-3010-94, Subsection 3.2.1 (Mishima 1994), states that under most realistic scenarios involving the heating of aqueous solutions during postulated accidents in nonreactor fuel cycle facilities, the relative vapor pressures of the solvent (water) and the solute (various compounds of radionuclides, generally acidic nitrate) preclude evaporation of the solute as a viable mechanism for the airborne release of the solute. Instead, the airborne release is postulated to result from the entrainment of minute drops of the bulk liquid formed by the mechanical disintegration of the surface of the bulk liquid. The mechanical disintegration mechanisms are, in essence, a result of boiling and aerodynamic breakup of the water surface. An upper bound of $5.3 \times 10^{-7}$ for the ARF resulting from evaporation can be taken from DOE-HDBK-3010-94, Table 3-1 (Mishima 1994). This ARF is based on a 2-hour sampling time for air flowing at $0.5 \mathrm{~m} / \mathrm{s}$ ( $1.6 \mathrm{ft} / \mathrm{s}$ ) over a water sample heated to $90^{\circ} \mathrm{C}\left(194^{\circ} \mathrm{F}\right)$.

Conservatively assuming an RF of 1.0 and a 24-hour accident time period, the total respirable airborne fraction is

$$
\left(5.3 \times 10^{-7} / 2 h\right)(1.0)(24 h)=6.36 \times 10^{-6} .
$$

The respirable release source term from evaporation is

$$
(5,000 \mathrm{gal})(3.7854 \mathrm{~L} / \mathrm{gal})\left(6.3^{6} \times 10^{-6}\right)=0.12 \mathrm{~L} \text {. }
$$

The respirable release source term for the spill accident is

$$
1.89+0.18+0.12=2.19 \mathrm{~L} \text {. }
$$

For the spray case, under the correct set of conditions, a portion of the liquid jet issuing from a leak will atomize and can be transported over large distances. Because atomization is a random process, the resultant spray consists of a wide range of drop sizes and must be represented by a distribution rather than by a single parameter. The types of leaks that might be encountered or postulated for the liquid handling system consist of corrosion-induced leakage, failure of gaskets, failure of Plutonium-Uranium Extraction Facility-type connectors, or weld failures. Correlations for atomization of liquid jets from plain circular orifices best represent the slit and circular hole leaks that could be encountered (Hey and Leach 1994). It is generally accepted that water droplets of $10 \mu \mathrm{m}$ diameter or less are respirable and can be kept al oft by air currents and hence transported relatively long distances from the release point. A droplet that originates in a spray at greater than $10 \mu \mathrm{m}$ can be reduced to less than $10 \mu \mathrm{m}$ by evaporation and then also be respirable. For this analysis, spray droplets up to $17 \mu \mathrm{m}$ diameter will be considered in the RF.

Verification cases for the SPRAY computer code, Version 3.0 (Hey and Leach 1994), included five "typical" calculations that included the search for the orifice diameter that produced the highest respirable release rate. From these sample cases, the highest respirable release rate was $0.0352 \mathrm{~L} / \mathrm{min}$ $(0.00931 \mathrm{gal} / \mathrm{min})$, which was based on a differential pressure of $100 \mathrm{psi}$. (This code will be run to calculate a respirable release rate for liquid handling system operation at actual conditions. 
Assume that the spray continues for 10 hours based on current engineering estimates that the flow rate of the truck tank loading system is about $3.8 \mathrm{~L} / \mathrm{min}(10 \mathrm{gal} / \mathrm{min})$. The $3.8 \mathrm{~L} / \mathrm{min}(10 \mathrm{gal} / \mathrm{min})$ flowrate is assumed based on best information from the system designer. The respirable release source term from spray is

$$
(0.01 \mathrm{gal} / \mathrm{min})(3.7854 \mathrm{~L} / \mathrm{gal})(60 \mathrm{~min} / \mathrm{h})(10 \mathrm{~h})=22.71 \mathrm{~L} \text {. }
$$

A large fraction of the sprayed water will fall to the floor and collect in a pool, and this pool could evaporate, contributing to the release source term. As demonstrated above for the spill case, the contribution of evaporation is negligible.

The bounding liquid release accident is therefore a spray accident. The estimated inventory released for this case is $22.71 \mathrm{~L}$ of central holding tank water.

Consequence Analysis. The released source term is used to determine the radiological doses to onsite and offsite receptors. The following assumptions have been used to determine radiological consequences to human receptors.

- The release is caused by a breach of the liquid handling system integrity.

- Only short-term exposure effects resulting from inhalation are evaluated.

- There is no credit for building confinement.

- The committed EDE per unit intake is $4.3 \times 10^{3} \mathrm{SV} / \mathrm{g}$ $\left(4.3 \times 10^{5} \mathrm{rem} / \mathrm{g}\right)$ of fuel oxide (Huang 1995$)$.

- The values of $X / Q$ for the selected receptor location are those given in Table 4-4 for ground-level releases without plume meander.

- The radionuclide concentration of the water in the central holding tank is determined on the following basis. The MCOs are loaded with washed fuel in the $K$ Basins and then the void volume in the shipping cask-MCO assembly, which includes the MCO itself and the annulus between the shipping cask and the $\mathrm{MCO}$, is filled with demineralized water. The cask-MCO as sembly is then transported to the CVDS for processing. During transportation and setup of the MCO for cold vacuum drying, the fuel can chemically react and form additional oxide that can dissolve and/or be suspended in the water. The exact amount of water in an MCO is a function of the volume of fuel loaded and will vary somewhat but will be approximately 568 L (150 gal). This MCO water is pumped into a waste liquid holding tank (757 L [200 gal]) and then pumped to the central holding tank $(18,900 \mathrm{~L}$ $[5,000 \mathrm{ga}]])$. The system is then flushed with $568 \mathrm{~L}$ (150 gal) of demineralized water that mixes with the MCO water already in the central holding tank. The central holding tank is expected to be filled to near capacity and then be emptied (approximately every three weeks) to a tank trailer for transportation to another 
facility. Details of this liquid handling system are not finalized, but it is estimated that a relatively low pressure (much less than 50 psig) pump will be used, and the flowrate is estimated to be in the neighborhood of $3.8 \mathrm{~L} / \mathrm{min}(10 \mathrm{gal} / \mathrm{min})$, which would result in a loading time of more than 8 hours ( 10 hours is assumed in this analysis).

The $16.0 \mathrm{~kg}$ of particulate originally loaded into an MCO is assumed not to be available for release in the liquid stream because all free and available particulate is assumed to be removed during the fuel washing step prior to loading fuel into the $\mathrm{MCO}$. However, the $0.72 \mathrm{~kg}$ of particulate that may be generated in the $\mathrm{MCO}$ after loading is assumed to be free and available in the liquid stream. Therefore, the amount of fuel oxide assumed to be removed from each MCO during flushing in this calculation is $0.72 \mathrm{~kg}(1.59 \mathrm{lb})$ (Cowan 1996). This $0.72 \mathrm{~kg}$ (1.59 1b) of oxide will be mixed with $1,136 \mathrm{~L}(300 \mathrm{ga})$ ) of water ( $568 \mathrm{~L}[150 \mathrm{gal}]$ from the cask-MCO assembly and $568 \mathrm{~L}$ [150 gal] from the flushing operation), which yields a radionuclide concentration of

$$
[(0.72 \mathrm{~kg})(1,000 \mathrm{~g} / \mathrm{kg})] /[(300 \mathrm{ga} 7)(3.7854 \mathrm{~L} / \mathrm{ga}])]=0.634 \mathrm{~g} / \mathrm{L} \text {. }
$$

The unmitigated EDE for the onsite receptor (100 $\mathrm{m}$ [328 ft]) that results from the bounding liquid release accident is calculated as

$$
\begin{aligned}
D & =M \times \text { concentration } \times \frac{X}{Q} \times R \times C \\
& =(22.7 \mathrm{~L})\left(0.634 \frac{\mathrm{g}}{\mathrm{L}}\right)\left(7.32 \times 10^{-2} \frac{\mathrm{s}}{\mathrm{m}^{3}}\right)\left(3.3 \times 10^{-4} \frac{\mathrm{m}^{3}}{\mathrm{~s}}\right)\left(4.3 \times 10^{3} \frac{\mathrm{SV}}{\mathrm{g}}\right) \\
& =1.5 \mathrm{SV}(150 \mathrm{rem}) .
\end{aligned}
$$

Dose consequences calculated in the same manner for other selected receptors are given in the Table 4-11.

Summary of Safety Class Requirements. If this accident is not mitigated or prevented by designed safety features, the radiological dose consequence to the onsite receptor $100 \mathrm{~m}(328 \mathrm{ft}$ ) from the facility is $1.5 \mathrm{SV}$ (150 rem). The dose to the receptor at the nearest river bank $(480 \mathrm{~m}[1,575 \mathrm{ft}])$ is $4.39 \times 10^{-2}$ SV $(4.4 \mathrm{rem})$, the dose to the receptor at the fire station $(4,000$ $m[13,120 \mathrm{ft}])$ is $3.00 \times 10^{-3} \mathrm{~Sv}(0.300 \mathrm{rem})$, and the dose to the offsite receptor at the Hanford Site boundary is $7.31 \times 10^{-4} \mathrm{~Sv}(0.073 \mathrm{rem})$. These doses exceed those permitted by WHC guidelines (WHC-CM-4-46). This mandates mitigative or preventive administrative controls or design features designated safety significant. This function could be met by a monitoring and detection system with appropriate administrative control response or by an appropriate water filtration system at or near the outlet of the MCOs. In addition to limiting potential doses resulting from liquid release accidents, such a filtration system would reduce workers' radiation exposure and reduce cleanup 
Table 4-11. Calculated Dose Consequences for Liquid Releases.

\begin{tabular}{|c|c|c|c|}
\hline \multirow{2}{*}{ Receptor location } & \multicolumn{2}{|c|}{$\begin{array}{c}\text { Unmitigated release } \\
\text { (point source, without stack or } \\
\text { plume meander) }\end{array}$} & \multirow{2}{*}{$\begin{array}{l}\text { Guidelines } \\
\text { Sv (rem) }\end{array}$} \\
\hline & $\begin{array}{l}x / 9 \\
\mathrm{~s} / \mathrm{m}^{3}\end{array}$ & $\begin{array}{c}\mathrm{EDE} \\
\text { Sv }(\mathrm{rem})\end{array}$ & \\
\hline $\begin{array}{c}\text { Onsite } \\
(100 \mathrm{~m} \mathrm{E})\end{array}$ & 7.32 E-02 & $\begin{array}{c}1.5 \\
(150 \text { rem })\end{array}$ & $\begin{array}{l}5.0 \text { E-02 } \\
(5.0 \text { rem) }\end{array}$ \\
\hline $\begin{array}{c}\text { Near river bank } \\
(480 \mathrm{~m} \mathrm{NW})\end{array}$ & $2.15 \mathrm{E}-03$ & $\begin{array}{cc}4.39 & E-02 \\
(4.39 & \text { rem) }\end{array}$ & -- \\
\hline $\begin{array}{l}\text { Fire station } \\
(4,000 \mathrm{~m} \text { ESE) }\end{array}$ & $1.47 \mathrm{E}-04$ & $\begin{array}{c}3.00 \mathrm{E}-03 \\
(3.00 \mathrm{E}-01 \mathrm{rem}\end{array}$ & $\begin{array}{l}5.0 \mathrm{E}-02 \\
(5.0 \text { rem })\end{array}$ \\
\hline $\begin{array}{c}\text { Hanford Site boundary } \\
(12,040 \mathrm{~m} \mathrm{~W})\end{array}$ & $3.58 E-05$ & $\begin{array}{c}7.31 \quad \text { E-04 } \\
(7.31 \text { E-02 rem) }\end{array}$ & $\begin{array}{l}5.0 \text { E-03 } \\
(0.5 \text { rem })\end{array}$ \\
\hline
\end{tabular}

Note:

Guidel ines are from HHC-CM-4-46, Nonreactor Facility Safety Analys is Manual, Westinghouse Hanford Company, Richland, Washington.

$E D E=$ effective dose equivalent.

costs associated with decommissioning the CVDS. The effectiveness required of this filtration system would be determined on the basis of a more detailed evaluation of the liquid release accidents associated with the liquid handling system. The current analysis could possibly be improved by realistically assessing some of the conservative input parameters associated with the calculations.

\subsection{ACCIDENT ANALYSIS SUMMARY}

Unmitigated onsite and offsite dose consequences for the representative and bounding accidents in Section 4.1 have been calculated. In each case, the unmitigated consequences are such that the safety-class criterion in WHC-CM-4-46, Section 9.0, is reached. Table 2-1 provides a summary of the anticipated safety-c\}ass SSCs required by the accident analysis.

Finalizing the design approach for mitigation of the accidents will be completed before final design submittal. The design approach will consider the operating philosophy and cost-effectiveness of the design alternatives and will be coordinated with the accident analysis.

\subsection{CONSTRUCTION HAZARDS}

Construction hazards are short-term risks during construction of the structures and systems and during equipment installation and removal operations. These hazards are discussed in Chapter 5.0. 


\subsection{CONSTRUCTION RISKS}

The CVDS facility will be constructed in the 100 Area of the Hanford Site approximately $122 \mathrm{~m}$ ( $400 \mathrm{ft}$ ) southwest of the $\mathrm{K}$ West Reactor Building. The nearest building not associated with the CVDS is the 165-KW Power control Building located $69 \mathrm{~m}(225 \mathrm{ft})$ east of the CVDS facility.

\subsection{CONSTRUCTION AND MODIFICATION ACTIVITIES}

There are no physical features of the CVOS that will require unique construction activities. With a distance of approximately $122 \mathrm{~m}(400 \mathrm{ft})$ between the construction site and the nearest nuclear facility and with no unique construction activities involved, the construction of the CVDS will not present a hazard to nearby facilities.

\subsection{WASTE MINIMIZATION AND HAZARDOUS MATERIAL USAGE DURING CONSTRUCTION}

The CVOS Project will minimize the use of hazardous materials and the generation of hazardous and nonhazardous waste during construction. Some materials used for construction will not be considered hazardous until they are designated as waste. Where materials are used that are hazardous or will become hazardous upon designation as a waste, a note or similar identification will be added to the detailed design specification to require that material safety data sheets be supplied. Material safety data sheets will be supplied for all potentially hazardous materials (i.e., paints, sealants, oils, Tubricants, chemicals, fill fluids). No polychlorinated biphenyls or asbestos will be allowed. Transformers, lighting ballasts, and other electrical equipment that use an insulating oil will be certified as polychlorinated biphenyl-free. Such certification will be requested in the materials and equipment specifications. 
WHC-SD-SNF-PSE-003 REV 0

This page intentionally left blank. 
WHC-SD-SNF-PSE-003 REV 0

\subsection{SAFETY DOCUMENTATION}

This chapter identifies additional safety documentation required to support the CVDS.

\subsection{DESIGN DOCUMENTATION}

\subsubsection{Multicanister Overpack Topical Report}

The MCO containers will be used for packaging, shipping, staging, fuel conditioning, and interim dry storage functions. The safety bas is of the MCOS, including design, manufacture, and testing associated with production and use, will be evaluated and documented in an MCO topical report. Accident analyses involving the MCOS will be included in the FSARs for the CSB, the CVDS, and the Hot Conditioning Annex, in the onsite safety analysis report for packaging, and in the $K$ Basins modification documentation rather than in the MCO topical report.

\subsubsection{Criticality Safety Evaluation Report}

A criticality safety evaluation report will document evaluation of the criticality safety of the equipment and operations involving fissionable material for normal and credible abnormal conditions. The criticality safety evaluation report will document the existing equipment design and administrative controls that meet or exceed the margin of safety required by DOE Order 5480.24, Nuclear Criticality Safety. The report al so will address the need to maintain the value of $k_{\text {ff }}$ at or below 0.95 as required by NRC nuclear safety equivalency (Garvin 1995). The criticality safety evaluation report will be issued and approved before operations involving fissionable materials begin.

\subsubsection{Safety Analys is Report}

An FSAR will document the safety analysis for the CVDS to ensure that the facility can be operated, maintained, shut down, and decommissioned safely and in compliance with applicable laws and regulations. The FSAR will be prepared using the format and content guidance provided in DOE-STD-3009-94. In consideration of conditioning processes and safety features, the CVDS FSAR will be augmented by relevant information called for in Regulatory Guide 3.25 , Standard Format and Content of Safety Analysis Reports for Fuel Reprocessing Plants (NRC 1975), that is not required in DOE 5480.23 and DOE-STD-3009-94 and that is unique to the cold vacuum drying process. 


\subsubsection{Technical Safety Requirements}

Technical safety requirements will be developed that define the conditions, safe boundaries, and management or administrative controls necessary to ensure safe operation of the CVDS. The requirements will reduce the potential risk to employees and the public from uncontrolled releases of radioactive material and radiation exposures caused by inadvertent criticality. The technical safety requirements witl be developed in accordance with DOE Order 5480.22, Technical Safety Requirements, and will be based on the operational limits established in the CVDS FSAR to ensure that CVOS operation is maintained within the bounds assumed in the safety analyses. The final technical safety requirements will be contained in a separate document issued by WHC and approved by DOE before CVOS operations begin.

\subsubsection{Fire Hazard Analysis}

A fire hazard analysis will be performed to assess the risk from fire in the CVDS in relation to proposed fire protection. The analysis will include descriptions of CVDS construction, protection provided for essential safetyclass equipment, fire hazards, exposure fire potential, i ife safety considerations, high-value property, expected fire brigade and fire department responses, recovery potential, emergency planning, and security. The fire hazard analysis will be performed under the direction of a qualified fire protection engineer and will satisfy the requirements of DOE Order 5480.7A, Fire Protection, DOE Order 6430.1A, and WHC-CM-4-41, Fire Protection Program Manual, Section 3.4, "Fire Hazard Analysis Requirements."

\subsection{QUALITY ASSURANCE DOCUMENTATION}

Public safety, onsite worker safety, and protection of the environment are overriding considerations for the SNF CVDS Project. The commitment to safety by the DOE dictates management and verification activities to ensure that safety and environmental considerations are reflected in the design, procurement, construction, and operation of the CVDS. Quality assurance is all of those planned and systematic actions necessary to provide adequate confidence that SSCs will perform satisfactorily in service.

CVDS Project quality-affecting activities will comply with the applicable requirements of Title 10, Code of Federal Regulations, Part 830, "Nuclear Safety Management," Section 830.120, "Quality Assurance Requirements;" 10 CFR 72, Subpart G, "Quality Assurance;" and D0E/RW/0333P, Quality Assurance Requirements and Description for the Civilian Radioactive Waste Hanagement Program (DOE 1995). A WHC project-specific quality assurance program plan that implements and executes the applicable requirements of 10 CFR 830.120 ; 10 CFR 72, Subpart G; and DOE/RW/0333P (DOE 1995) will be prepared for the CVDS project.

The specific SNF CVOS Project functions, SSCs, and activities that are required to be in compliance with the applicable requirements of $\mathrm{DOE} / \mathrm{RW} / 0333 \mathrm{P}$ (DOE 1995), wił1 be identified in WHC-SD-SNF-RPT-007, Application of the 
Office of Civilian Radioactive Waste Management Quality Assurance Requirements to the Hanford Spent Nuclear Fuel Project (WHC 1996).

The SNF CVDS Project quality assurance program will be structured to ensure that the design, procurement, fabrication, installation, construction, testing, and operation of SSCs will minimize or eliminate the following conditions:

- Undue risk to the health and safety of the public

- Violations of regulations and standards

- Prejudice of the operability and reliability of systems

- Waste in a form unacceptable for long-term interim storage.

The CVDS quality assurance program plan is being prepared and will be issued in the near future. The quality assurance program plan will contain quality assurance requirements to be met by WHC and all other contractors when performing quality-affecting work for the CVDS.

Contractors will perform quality-affecting activities for cVDS in accordance with a documented quality assurance program plan that is compatible with those requirements of 10 CFR 830.120 ; 10 CFR 72, Subpart G; and DOE/RW/0333P (DOE 1995) that are applicable to the contractors' scope of work. Contractor's quality assurance program plans will be submitted to the SNF Project Quality Assurance organization, upon request, for review and approval.

\subsection{SAFEGUARDS AND SECURITY DOCUMENTATION}

The Safeguards and Security Department maintains around-the-clock surveillance of the Hanford Site to isolate potential hazards and to protect government property, classified information, and special nuclear material. The Hanford Patrol maintains a continuous presence of armed guards to provide security for the Site. Manned barricades are maintained at checkpoints on the vehicle access roads from Richland and Yakima, Washington. While on Site, personnel must display a badge indicating authorization to enter the Hanford Site.

No special security and safeguard requirements are needed for the CVDS beyond those currently in force at such locations as the $K$ Basins. The CVDS will conform with the security and safeguards requirements defined in $D O E$ orders and WHC policies and procedures. Fencing, access locks, and any other necessary security or safeguard measures will be provided to meet DOE requirements, environmental regulations, and WHC policies and procedures for construction and operation of the CVDS. 
WHC-SD-SNF-PSE-003 REV 0

This page intentionally left blank. 


\subsection{PROJECT INTERFACES}

\subsection{FACILITY AND DESIGN INTERFACES}

The CVOS has facility and design interfaces with $K$ Basins and with $K$ Basins activities (including desludging and cleaning of the SNF, reracking, and loading of the MCOS), with the CSB and the Hot Conditioning Annex, with $M C O$ design and fabrication, and with shipping cask-MCO transport. These activities are described in Section 2.1 .

The potential hazards involved in these interfaces are identified in the PHA in Appendix A. Of particular interest is the particulate content of fuel that has not been properly washed or inspected (e.g., has excessive free particulate) that could be delivered to the CVDS from the $K$ Basins. The CVDS accident anaiyses assume a maximum particulate content of $16 \mathrm{~kg}$ ( $35.31 \mathrm{~b})$ in the $M C O S$ received from $K$ Basins. The particulate content is primarily controlled by $K$ Basins activities. However, transport and CVDS operations could form more oxide particulate. This is accounted for in the analysis assumptions. However, $K$ Basin MCO loading should not result in an MCO that exceeds the $16 \mathrm{~kg}$ ( $35.3 \mathrm{1b})$ particulate 1 imit. Maintaining the $16 \mathrm{~kg}$ (35.3 ib) limit of particulate is the primary function of fuel loading at K Basins.

The MCO's design, fabrication, and shipping interfaces with the $K$ Basins have the potential to deliver a defective MCO to the facility. The consequences of these conditions have been considered in the PHA and the accident analysis in Chapter 4.0 .

\subsection{ACTIVITY INTERFACES}

\subsubsection{U.S. Department of Energy Spent Nuclear Fuel Project Division}

The DOE Spent Nuclear Fuel Project Division is responsible for the overall management and administration of CVDS Project activities, as well as assessment of CVDS Project performance and maintenance of the Project. baselines. The Spent Nuclear Fuel Project Division also ensures that required levels of quality, safety, and environmental compliance are achieved within estabijshed technical, cost, and schedule baselines. The U.S. Department of Energy, Richland Operations office (DOE-RL) manager has been assigned the authority of the Acquisition Executive for the CVDS Project. The DOE Spent Nuclear Fuel Project Division has the responsibility and authority to

- Provide review and approval of CVDS documents, including required environmental and safety documentation

- Approve overall scope, cost, and schedule baselines for the project

- Monitor and maintain overview of project activities, costs, schedules, and status to ensure project performance, quality, cost, and schedule objectives are met 
- Issue project authorizations for expense and capital funding as required by DOE-RL

- Provide direction to SNF Projects that is consistent with national program and policy direction.

\subsubsection{Organizational Support}

WHC and ICF Kaiser Hanford Company will support the project through various organizations. The following is a list of each support function and responsible organization. Additional detail for each of the listed functions is provided in WHC-SD-W441-PMP-001, Project W-441 Cold Vacuum Drying Project Management Plan (Byrd 1996).

- Quality Assurance. Quality assurance support is provided by WHC SNF Project Quality Assurance organization.

- Procurement. Procurement support is provided by the WHC Procurement and Materials Management Architect-Engineer and Major Subcontracts organization.

- Safety Oversight. Safety oversight will be conducted by the SNF Safety organization.

- Project Control. Project control support will be provided by WHC Construction Projects SNF Project Business Management organization.

- Technical Integration. Technical integration will be provided by the ICF Kaiser Hanford Company Engineering organization.

- Construction Management. The construction management function will be performed by ICF Kaiser Hanford Company.

- Permitting and Regulatory Program. Permitting and regulatory activities will be performed by the WHC SNF Regulatory Integration/Public Involvement organization.

- Safety Integration. Safety integration activities will be performed by the SNF' Engineering organization.

- Startup. Startup activities will be performed by the SNF CVDS startup organization.

- Dperations. Operations activities will be provided by the $K$ Basin operations organization.

\subsubsection{Architect-Engineer}

The architect-engineer, Merrick \& Company, is serving as the design agent for the SNF CVDS Project. The design agent produces the preliminary and definitive designs using engineering analysis and calculations. The design 
agent is responsible for providing the technical adequacy and design documentation (normally drawings, sketches, specifications, and engineering change notices) according to the design requirements defined by the WHC design authority.

The architect-engineer provides the conceptual and detail design for the CVDS in accordance with CVDS functions and requirements and CVDS performance specifications. The architect-engineer is responsible for providing technical adequacy in the development of the engineering baseline definition through production of process flow diagrams, piping and instrumentation drawings, general arrangement drawings, architectural drawings, and electrical one-line diagrams. Direction on work scope detail is transmitted through a formal statement of work from WHC.

Merrick \& Company also will provide Title III Engineering Services during construction.

\subsubsection{Construction Manager}

The construction manager will be ICF Kaiser Hanford Company. Responsibilities of the construction manaer include controlling the CVDS site, establishing the site usage plan, identifying subcontractor areas within the site boundary, approving subcontractor documents, writing and resolving nonconformance reports, providing inspection and testing for ali construction activities, reviewing and approving constructibility of the design, and performing inspections of critical components and characteristics.

\subsubsection{Facility Safety Evaluation Reviews}

DOE will review and approve documentation establishing the regulatory and technical safety basis for the CVDS. Within the WHC organization, approval responsibility and authority is delegated to the director of the SNF Project. Appropriate reviews are conducted by vendors, the SNF Project staff, and independent WHC safety and quality assurance staff. Additional reviews developed specifically to support the K Basins SNF Project will be provided as discussed below.

7.2.5.1 Regulatory Requirements Team. The Regulatory Requirements Team as a body is thoroughly familiar with DOE and NRC regulatory requirements. The members of the team have been selected for their knowledge and from DOE Headquarters, DOE-RL, and the various operating contractor organizations involved with the SNF Project. Membership also includes outside consultants. The Regulatory Requirements Team as a body is impaneled to support the SNF Project in its mission and, as such, the team advises and reports to the director of the Spent Nuclear Fuels Division at DOE-RL.

7.2.5.2 Independent Review Pane1. The Independent Review Panel is composed of three members with broad technical background, selected for their professional stature, technical capability, and experience. The Independent Review Panel reports to the Office of the Manager, DOE-RL, providing advice and high-level oversight of regulatory policy implementation. In order to 
accomplish this function, the panel conducts interviews, reviews documents, and attends presentations conducted by SNF Project and DOE-RL personne?. Specifically, the panel

- Reviews and concurs with the SNF Project's regulatory strategy

- Provides evaluation of and concurrence with the regulatory requirements document established by the SNF Project

- Provides evaluation of and concurrence with the safety analysis report and criticality safety evaluation report

- Provides concurrence with the safety basis for final approval to operate SNF Project facilities. 
WHC-SD-SNF-PSE-003 REV 0

\subsection{ITEMS REQUIRING FURTHER RESOLUTION}

During the completion of this PSE, key assumptions were made that will need to be confirmed before the CVDS design and safety analysis process is finalized.

- Preparation of the fue 7 for transport at $K$ Basins in the 100 Area will include removal of sludge and loose material by washing and visually examining the fuel as part of the loading preparation. A maximum particulate content of $16 \mathrm{~kg}$ (35.3 1b) will remain in the MCO from loading at K Basin. In addition, another $0.72 \mathrm{~kg}$ (1.59 1b) of particulate can form from the corrosion oxidation reaction occurring over the period of time between the loading of the SNF at $K$ Basins and completion of cold vacuum drying at the cVDS. For analysis purposes we conservatively assume all of the particulate forms during transport for a maximum MCO particulate content of $16.72 \mathrm{~kg}(36.86 \mathrm{lb})$ per MCO arriving at the CVDS.

To confirm this assumption, the packaging operations at $K$ Basins will be evaluated to determine whether human error or an accident could cause increased particulate loading in the MCOs that are shipped to the CVDS. The effect of the moisture on chemical reaction kinetics and hydrogen generation will be evaluated by the technology acquisition plan.

- Fire is not an initiating event for MCO failure.

To confirm this assumption, a fire hazard analysis must be completed for the CVDS facility to identify additional safety-class and safety-significant features if such features are required to satisfy offsite and onsite radiological exposure limits.

- Releases of toxic chemicals will not result in requirements for safety-class or safety-significant items.

Currently, no use of toxic chemicals has been identified in the current CVDS design or plans for operation. This assumption will be confirmed during the design at a later date.

- Particulate material from the MCO that drains into the process holding tanks will not accumulate in sufficient quantities to pose a criticality hazard.

Design information on the potential for particulate buildup in the liquid streams from the MCO and detection of material buildups is not yet available to assess this potential hazard. This will be addressed by the criticality safety evaluation report at a later date. Based upon the criticality safety evaluation report results, any safety-class or safety-significant features to ensure criticality safety in the process systems will be addressed in the design. 
- The hazard posed by the reactivity and ignition characteristics of fuel is bounded by the hazards and accident analyses examined in this PSE.

Reactivity and ignition characteristics of fuel are not yet available and therefore are not examined in this PSE. Information obtained by the technology acquisition plan will be incorporated into the analyses so that releases associated with MCOs containing fuel can be evaluated in the safety analysis report.

- The rapid MCO overpressure event and release will not impact the integrity of the building confinement boundary including ventilation ducting and high-efficiency particulate air filters.

An analysis will be performed to ensure the $M C O$ overpressure event does not fail the building confinement.

- The CVDS building is being designed to mitigate the effects of NPHs as defined in Section 2.2.2. It is assumed the building confinement and any safety-class functions will be designed to these NPH criteria and will not fail. The effects of NPH events beyond those defined are considered to be beyond design basis accidents.

Analyses will be performed to show the safety-class functions are adequately designed for NPH criteria. 


\subsection{REFERENCES}

\subsection{ACTS AND CODES}

10 CFR 72, "Licensing Requirements for the Independent Storage of Spent Nuclear Fuel and High-Level Radioactive Waste," Code of Federal Regulations, as amended.

10 CFR 830, "Quality Assurance," Code of Federal Regulations, as amended.

\subsection{DOCUMENTS}

Bradshaw, F. W., 1996, Cold Vacuum Drying Facility Preliminary Hazard Category and Analysis (Letter 9651761 to K. Ellard, Merrick \& Company, April 16), Westinghouse Hanford Company, Richland, Washington.

Byrd, L. C., 1996, Project W-441 Cold Vacuum Drying Project Management Plan, WHC-SD-W441-PMP-001, Rev. 0, Westinghouse Hanford Company, Richland, Washington.

Clifford, J. W., 1996, Revision of Tornado Design Criteria for the Hashington Public Power Supply System (WPPSS) Nuclear Project No. 2 (WNP-2)

(TAC No. 88626) (Letter GI2-96-032 to J. V. Parrish, Washington Public Power Supply System, January 24), U.S. Nuclear Regulatory Commission, Washington, D.C.

Croff, A. G., 1980, A Users Manual for the ORIGEN2 Computer Code, ORNL/TM-7175, Oak Ridge National Laboratory, Oak Ridge, Tennessee.

Crow], D. A., and J. F. Louvar, 1990, Chemical Process Safety: Fundamentals with Applications, Prentice Hall, Englewood Cliffs, New Jersey.

Cowan, R. G., 1996, Bounding Particulate Contents of a Multicanister Overpack, WHC-SD-SNF-TI-023, Rev. 0, Westinghouse Hanford Company, Richland, Washington.

DOE, 1995, Quality Assurance Requirements and Description for the Civilian Radioactive Waste Management Program, D0E/RW/0333P, Office of Civilian Radioactive Waste Management, U.S. Department of Energy, Washington, D.C.

EPA, 1988, Limiting Values of Radionuclide Intake and Air Concentration and Dose Conversion Factors for Inhalation, Submersion, and Ingestion, EPA/520/1-88/020, U.S. Environmental Protection Agency, Washington, D.C.

Fulton, J. C., 1994, Hanford Spent Nuclear Fuel Project Recommended Path Forward, WHC-EP-0830, Rev. 0, Westinghouse Hanford Company, Richland, Washington.

Garvin, L. J., 1995, Spent Nuclear Fuel Project Path Forward Additional NRC Requirements, WHC-SD-SNF-DB-003, Rev. 0, Westinghouse Hanford Company, Richland, Washington. 
Grumbly, T. P., 1995, Concurrence with the K-Basins Spent Nuclear Fuel Program Policy on Nuclear Safety Requirements, EM-36-3.1.6.7 (Memo to Manager, U.S. Department of Energy, Richland Operations Office, July 20), U.S. Department of Energy, Washington D.C.

Hey, B. E., 1993a, GXQ Program Users' Guide, WHC-SD-GN-SWD-30002, Rev. 1, Westinghouse Hanford Company, Richland, Washington.

Hey, B. E., 1993b, GXQ Program Verification and Validation, WHC-SD-GN-SWD-30003, Rev. 0, Westinghouse Hanford Company, Richland, Washington.

Hey, B. E., and D. S. Leach, 1994, Safety Analysis Standard-Predicting Respirable Release from Pressurized Leaks, WHC-SD-GN-SWD-20007, Rev. 0, Westinghouse Hanford Company, Richland, Washington.

Hey, B. E., 1995, Revision 1 to Supporting Calculations for $K$ Basin ISB (Internal Memo 80150-BEH-94-003 R1 to J. R. Brehm, June 12), Westinghouse Hanford Company, Richland, Washington.

Huang, C. H., 1996, Unit Dose Calculation for the $K$ Basins Safety Regulatory Assessment Feed Basis, WHC-SD-WM-TI-742, Rev. 0, Westinghouse Hanford Company, Richland, Washington.

ICRP, 1975, Reference Man: Anatomical, Physiological, and Metabolic Characteristics, Publication 23, International Commission on Radiological Protection, Elmsford, New York.

Irwin, J. J., 1996, Performance Specification for the K-Basin SNF Low Temperature Vacuum Drying Module, WHC-S-0435, Rev. 0, Westinghouse Hanford Company, Richland, Washington.

Merrick, 1996, Cold Vacuum Drying System Conceptual Design Report, WHC-SD-SNF-COR-003, Rev. 0, Merrick and Company, Albuquerque, New Mexico, for Westinghouse Hanford Company, Richland, Washington.

Mishima, J., 1994, Airborne Release Fractions/Rates and Respirable Fractions/Rates for Nonreactor Nuclear Facilities, DOE-HDBK-3010-94, U.S. Department of Energy, Washington, D.C.

Napier, B. A., R. A. Peloquin, J. V. Ramsdell, and D. L. Strenge, 1988, GENII - The Hanford Environmental Radiation Dosimetry Software System, Vo1. 1, PNL-6584, Pacific Northwest Laboratory, Richland, Washington.

NRC, 1975, Standard Format and Content of Safety Analysis Reports for Fuel Reprocessing Plants, Regulatory Guide 3.26, U.S. Nuclear Regulatory Commission, Washington, D.C.

NRC, 1989, Standard Format and Content for the Safety Analysis Report for an Independent Spent Fuel Storage Installation or Monitored Retrievable Storage Installation (Dry Storage), Regulatory Guide 3.48 , U.S. Nuclear Regulatory Commission, Washington, D.C. 
Parrish, J. V., 1995, WHC-2, Operating License NPF-21, Request for Approval to Revise Tornado Design Criteria (Letter G02-95-212 to U.S. Nuclear Regulatory Commission, October 10), Washington Public Power Supply System, Richland, Washington.

Perry, R. H., and C. H. Chilton, 1973, Chemical Engineers' Handbook, McGraw-Hill Book Company, New York, New York.

Schwarz, R. A., 1995, Certification of RADNUC, WHC-SD-HWV-SWD-001, ReV. I, Westinghouse Hanford Company, Richland, Washington.

Sellers, E. D., 1996, Clarification of Site Boundary for Spent Nuclear Fuel Project (SNFP) Work in or near the $K$ Basins (Letter 96-SFD-113 to President, Westinghouse Hanford Company, May 22), U.S. Department of Energy, Richland Operations Office, Washington.

SFPE, 1992, The SFPE Handbook of Fire Protection Engineering, Society of Fire Protection Engineers, Boston, Massachusetts.

Tallman, A. M., 1996, Cold Vacuum Drying System Natural Phenomena Hazards, WHC-SD-SNF-DB-010, Rev. 0, Westinghouse Hanford Company, Richland, Washington.

Thomson, J. R., 1987, Engineering Safety Assessment, An Introduction, John Wiley and Sons, Incorporated, New York, New York.

Transnuclear, 1996, Preliminary Design Analysis Report for the TN-HHC Cask and Transportation System, Project 3035, Transnuclear, Incorporated, Hawthorne, New York.

WHC, 1995, Hanford Spent Nuclear Fuel Project Integrated Process Strategy for $K$ Basins Spent Nuclear Fuel, WHC-SD-SNF-SP-005, Rev. 0, Westinghouse Hanford Company, Richland, Washington.

WHC, 1996, Application of the Office of Civilian Radioactive Waste Management Quality Assurance Requirements to the Hanford Spent Nuclear Fuel Project, WHC-SD-SNF-RPT-007, Rev. 0, Westinghouse Hanford Company, Richland, Washington.

Willis, W. L., 1995, 105-K Basin Material Design Basis Feed Description for Spent Nuclear Fuel Project Facilities, WHC-SD-SNF-TI-009, Rev. OA, Westinghouse Hanford Company, Richland, Washington.

\subsection{U.S. DEPARTMENT OF ENERGY ORDERS AND STANDARDS}

DOE Order 4700.1, Project Management System, U.S. Department of Energy, Washington, D.C.

DOE Order 5480.4, Environmental Protection, Safety, and Health Protection Standards, U.S. Department of Energy, Washington, D.C. 
DOE Order 5480.7A, Fire Protection, U.S. Department of Energy, Washington, D.C.

DOE Order 5480.22, Technical Safety Requirements, U.S. Department of Energy, Washington, D.C.

DOE Order 5480.23, Nuclear Safety Analysis Reports, U.S. Department of Energy, Washington, D.C.

DOE Order 5480.24, Nuclear Criticality Safety, U.S. Department of Energy, Washington, D.C.

DOE Order 5480.28, Natural Phenomena Hazards Mitigation, U.S. Departinent of Energy, Washington, D.C.

DOE Order 5820.2A, Radioactive Waste Management, U.S. Department of Energy, Washington, D.C.

DOE Order 6430.1A, General Design Criteria, U.S. Department of Energy, Washington, D.C.

DOE-STD-1020-94, Natural Phenomena Hazards Design and Evaluation Criteria for Department of Energy Facilities, DOE Standard 1020-94, U.S. Department of Energy, Washington, D.C.

DOE-STD-3009-94, Preparation Guide for U.S. Department of Energy Nonreactor Nuclear Facility Safety Analysis Reports, DOE Standard 3009-94, U.S. Department of Energy, Washington, D.C.

\subsection{CONTROLLED MANUALS}

WHC-CM-4-41, Fire Protection Program Manual, Westinghouse Hanford Company, Richland, Washington.

WHC-CM-4-46, Nonreactor Facility Safety Analysis Manual, Westinghouse Hanford Company, Richland, Washington. 
WHC-SD-SNF-PSE-003 REV 0

APPENDIX A

PRELIMINARY HAZARD ANALYSIS 
WHC-SD-SNF-PSE-003 REV 0

This page intentionally left blank. 


\begin{tabular}{|c|c|c|c|c|c|c|c|c|c|}
\hline \multirow{2}{*}{$\begin{array}{c}\text { Accident/ } \\
\text { system }\end{array}$} & \multirow{2}{*}{$\begin{array}{c}\text { Potential } \\
\text { hazard }\end{array}$} & \multirow{2}{*}{ Causes } & \multirow[b]{2}{*}{ Consequences } & \multicolumn{2}{|c|}{ Safety features } & \multirow{2}{*}{$\begin{array}{c}\text { Inventory at } \\
\text { risk }\end{array}$} & \multirow{2}{*}{$\begin{array}{c}\text { Consequence } \\
\text { cat egory }\end{array}$} & \multirow{2}{*}{\begin{tabular}{|c|}
$\begin{array}{c}\text { F requency } \\
\text { category }\end{array}$ \\
\end{tabular}} & \multirow[b]{2}{*}{ Remarks } \\
\hline & & & & Engineered & Administrative & & & & \\
\hline $\begin{array}{l}1 . \text { a } \\
\text { Mco } \\
\text { receiving }\end{array}$ & $\begin{array}{l}\text { Truck fire in } \\
\text { recelving } \\
\text { facility }\end{array}$ & $\begin{array}{l}\text { Gasol ine or } \\
\text { diesel leak plus } \\
\text { ignition }\end{array}$ & $\mid \begin{array}{l}\text { Damage to cask-Mco } \\
\text { system by fire } \\
\text { and for structural } \\
\text { failure }\end{array}$ & \begin{tabular}{|l|} 
Partitions to \\
isolate loading \\
stations \\
10 cFR 71 fire \\
design; cask is \\
heat shield \\
Truek tractor, by \\
backing in \\
trailer, tractor \\
never completely \\
enters bay \\
Fire detection \\
and suppression \\
\end{tabular} & \begin{tabular}{|l} 
Fire \\
department \\
Prompt removal \\
of truck
\end{tabular} & $\begin{array}{l}\text { up to six } \\
\text { MCOS }\end{array}$ & s3 & 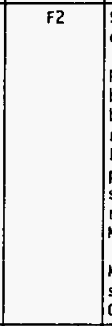 & $\begin{array}{l}\text { S3 is based on ore } \\
\text { or more MCOs vented. } \\
\text { Plan is to have } \\
\text { barriers between } \\
\text { bays, 1-2 hour } \\
\text { rating per UBC. } \\
\text { Fire-rated barriers } \\
\text { plus detection and } \\
\text { suppression could } \\
\text { reduce the number of } \\
\text { McOs at risk. } \\
\text { NorE: Compare with } \\
\text { simi lar accident in } \\
\text { cSB }\end{array}$ \\
\hline 1.b & \begin{tabular}{|l|} 
Worker \\
exposure to \\
exhaust gases \\
in truck \\
unl oading area
\end{tabular} & $\begin{array}{l}\text { Inadequate } \\
\text { ventilation }\end{array}$ & $\begin{array}{l}\text { Worker injury or } \\
\text { death }\end{array}$ & \begin{tabular}{|l|} 
Monitors and \\
alarms \\
Elephant trunk to \\
direct exhaust \\
gases out of the \\
bui lding \\
Unloading \\
facility \\
ventilation \\
system \\
Truck tractor, by \\
backing in \\
trailer, tractor \\
never completely \\
enters bay
\end{tabular} & $\mid \begin{array}{l}\text { Short duration } \\
\text { of vehicle } \\
\text { operation }\end{array}$ & NA & s1 & $F 3$ & \\
\hline $1 . \mathrm{c}$ & $\begin{array}{l}\text { Cask/trailer } \\
\text { tipping }\end{array}$ & \begin{tabular}{|l|} 
operator error \\
Inadecuately \\
secured load \\
Seismic event \\
Iruck mechanical \\
problem
\end{tabular} & $\begin{array}{l}\text { Damage to cask-Mco } \\
\text { syst tem or } \\
\text { support ing } \\
\text { equipment } \\
\text { Horker injury }\end{array}$ & \begin{tabular}{|l|} 
Partitions to \\
isolate stations \\
and protect from \\
externat loads \\
Center of \\
gravity, trailer \\
wheel width \\
spacing leads to \\
stabie design
\end{tabular} & $\begin{array}{l}\text { Procedures and } \\
\text { training } \\
\text { vehicte } \\
\text { mánintentintes }\end{array}$ & $\begin{array}{l}\text { One or tho } \\
\text { MCOS }\end{array}$ & 53 & 62 & $\begin{array}{l}\text { Potential for loss } \\
\text { of cooling on } \\
\text { adjacent station }\end{array}$ \\
\hline $1 . d$ & $\begin{array}{l}\text { Truck } \\
\text { collision }\end{array}$ & $\begin{array}{l}\text { Operator error } \\
\text { Iruck mechanical } \\
\text { probl em }\end{array}$ & \begin{tabular}{|l|} 
Damage to cask-MCO \\
systeml or \\
support ing \\
equipment \\
Horker injury \\
\end{tabular} & $\begin{array}{l}\text { wall partitions, } \\
\text { side and/or end } \\
\text { barriers or } \\
\text { curbing }\end{array}$ & \begin{tabular}{|l|} 
Procedures and \\
training \\
vehicle \\
maintenance
\end{tabular} & $\begin{array}{l}\text { one or two } \\
\text { MCOs }\end{array}$ & s3 & 52 & \\
\hline
\end{tabular}




\begin{tabular}{|c|c|c|c|c|c|c|c|c|c|}
\hline & 21 & IS & & & & Aunịu! sexjom & & & \\
\hline 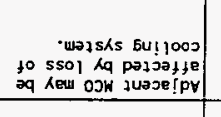 & 21 & Es & s2üJU0J OJK & 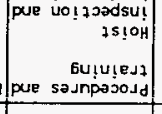 & 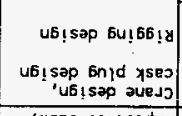 & 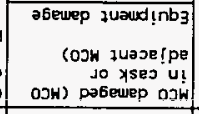 & 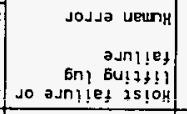 & p!is yeso do & 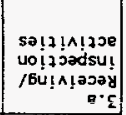 \\
\hline & 24 & £s & $\begin{array}{r}\text { SOJW } \\
\text { ק Jow Jo } 200 \\
\end{array}$ & & 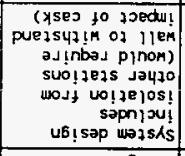 & 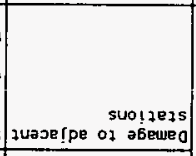 & & 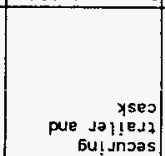 & \\
\hline 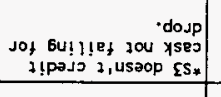 & 21 & $* \Sigma S$ & stuajuos oכH & $\begin{array}{r}\text { 6utulest } \\
\text { pue sasnpajosd }\end{array}$ & 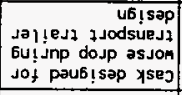 & 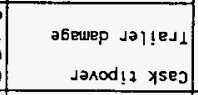 & 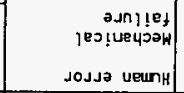 & 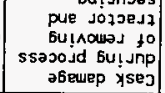 & 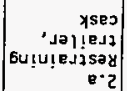 \\
\hline 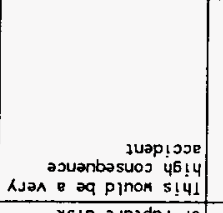 & \&] & IS & s2uajuos oJk & 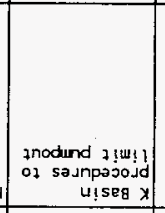 & 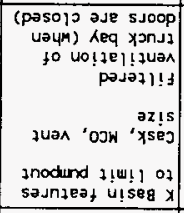 & 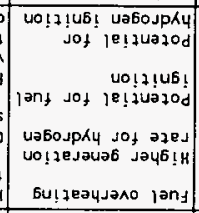 & 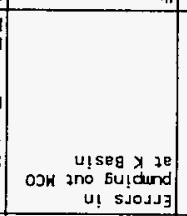 & 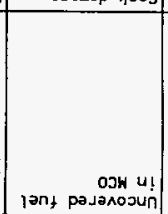 & 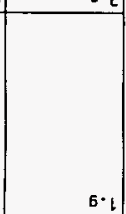 \\
\hline 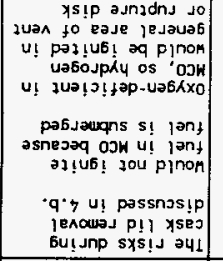 & 24 & is & 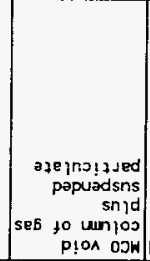 & 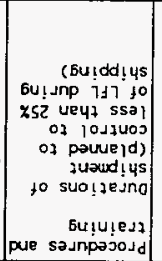 & 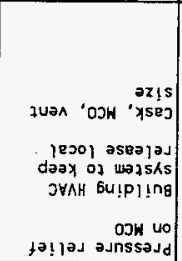 & 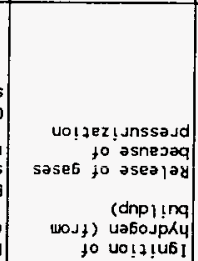 & 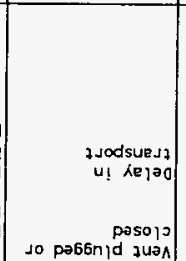 & 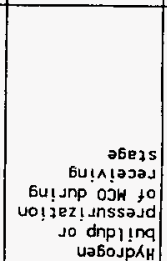 & 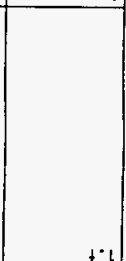 \\
\hline 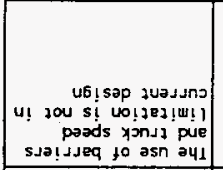 & 21 & ¿S & $\begin{array}{r}50 כ y \\
x ! 5 \\
01 \\
\end{array}$ & 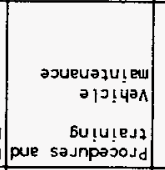 & 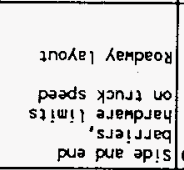 & 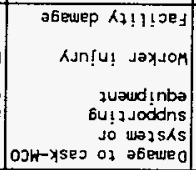 & 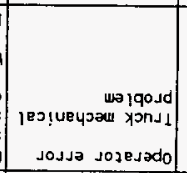 & | & $2 \cdot 1$ \\
\hline syjeway & 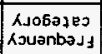 & \begin{tabular}{|c|} 
Luofazes \\
əouanbəsuoj
\end{tabular} & ze njs!u & 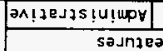 & 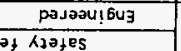 & sasuanbasuoj & sasnea & $\begin{array}{c}\text { PJezey } \\
\text { je!2uzjod }\end{array}$ & $\begin{array}{c}\text { wazs1s } \\
\text { hyap!30y }\end{array}$ \\
\hline
\end{tabular}




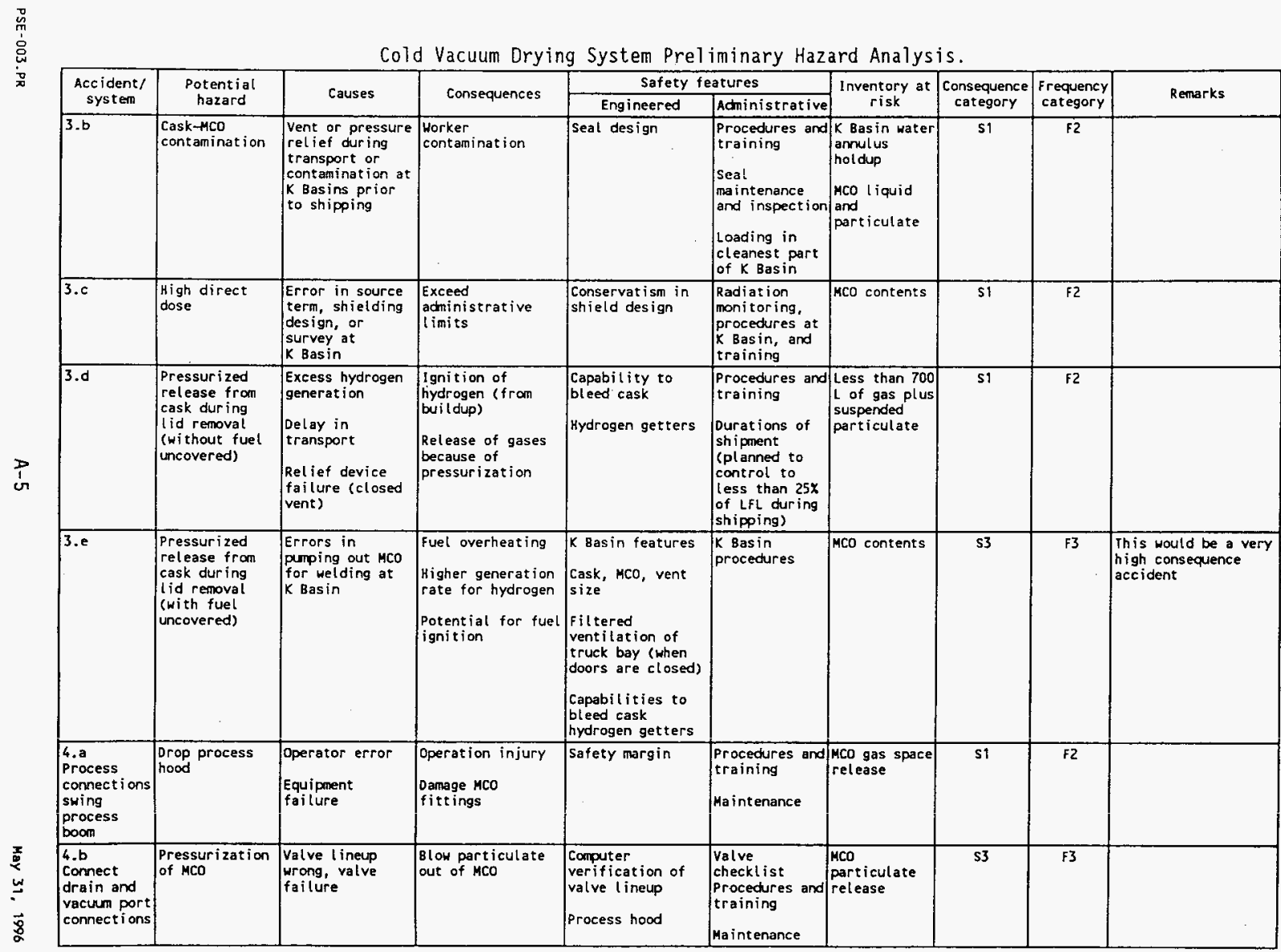




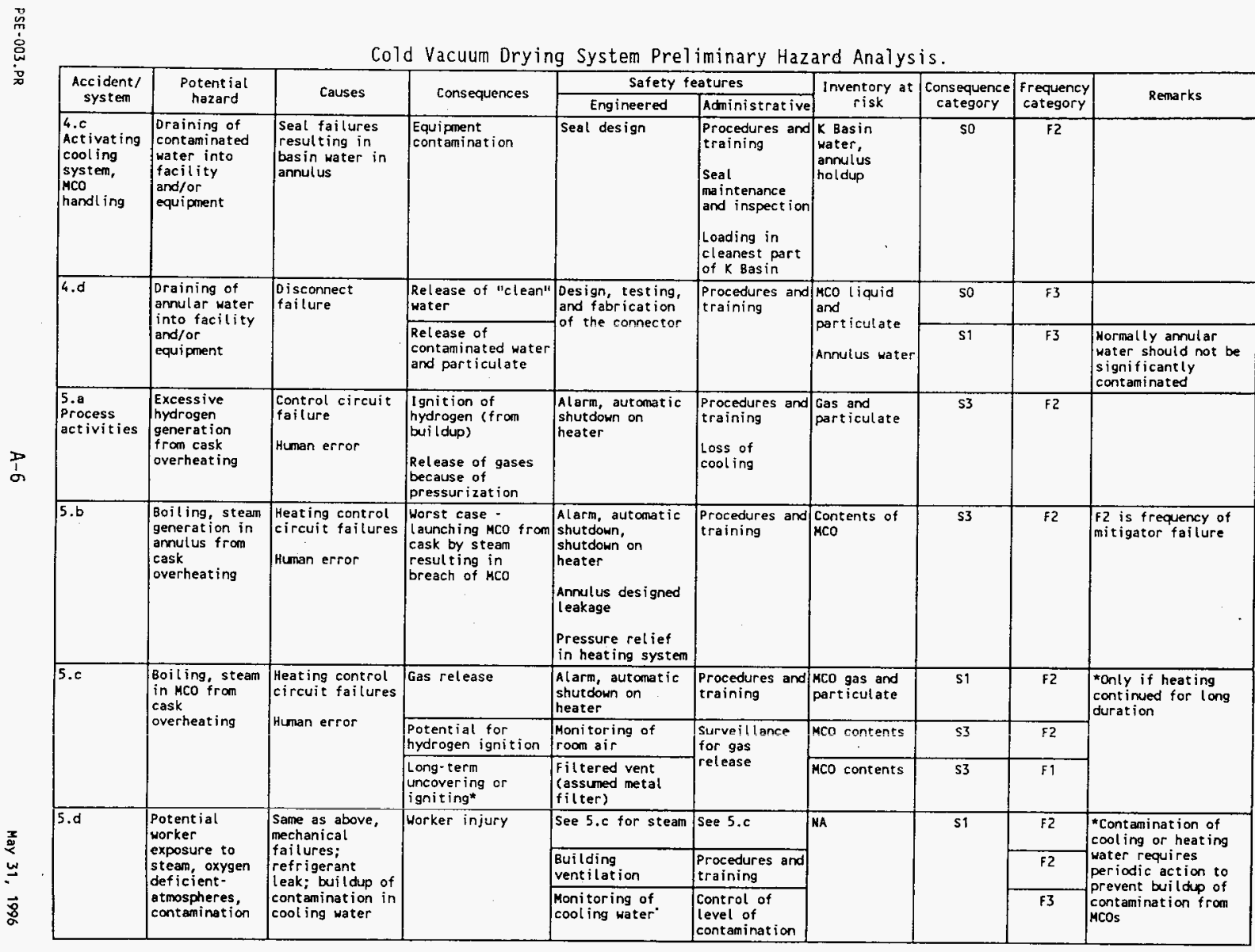


Cold Vacuum Drying System Preliminary Hazard Analysis.

\begin{tabular}{|c|c|c|c|c|c|c|c|c|c|}
\hline \multirow{2}{*}{$\begin{array}{l}\text { Accident/ } \\
\text { system }\end{array}$} & \multirow{2}{*}{$\begin{array}{l}\text { Potential } \\
\text { hazard }\end{array}$} & \multirow{2}{*}{ Causes } & \multirow{2}{*}{ Consequences } & \multicolumn{2}{|c|}{ Safety features } & \multirow{2}{*}{$\begin{array}{c}\text { Inventory at } \\
\text { risk }\end{array}$} & \multirow{2}{*}{$\begin{array}{c}\text { Consequence } \\
\text { category }\end{array}$} & \multirow{2}{*}{$\begin{array}{c}\text { Frequency } \\
\text { category }\end{array}$} & \multirow{2}{*}{ Remarks } \\
\hline & & & & Engineered & Adninistrative & & & & \\
\hline \multirow[t]{2}{*}{ 5.e } & \multirow[t]{2}{*}{$\begin{array}{l}\text { Loss of drain } \\
\text { line integrity } \\
\text { during } \\
\text { pressure test } \\
\text { or draining }\end{array}$} & \multirow[t]{2}{*}{$\begin{array}{l}\text { Improper } \\
\text { connection } \\
\text { Line failure } \\
\text { External event }\end{array}$} & $\begin{array}{l}\text { Spread of } \\
\text { contaminated water } \\
\text { Drain of } \\
\text { contaminated water } \\
\text { through floor } \\
\text { drain into } \\
\text { exterior retention } \\
\text { basin } \\
\end{array}$ & \multirow[t]{2}{*}{$\begin{array}{l}\text { pesign of drain } \\
\text { line hood and } \\
\text { ventilation } \\
\text { system }\end{array}$} & \multirow[t]{2}{*}{$\begin{array}{l}\text { Procedures and } \\
\text { training }\end{array}$} & \multirow[t]{2}{*}{$\begin{array}{l}\text { MCO water and } \\
\text { contents of } \\
\text { drain tank }\end{array}$} & *\$3 & 53 & \multirow[t]{2}{*}{$\begin{array}{l}\text { "Spray leak is less } \\
\text { likely than F3 }\end{array}$} \\
\hline & & & Worker exposure & & & & s1 & F3 & \\
\hline $5 . f$ & $\begin{array}{l}\text { Failure of } \\
\text { local drain } \\
\text { tank }\end{array}$ & $\begin{array}{l}\text { Material defect, } \\
\text { eorrosion } \\
\text { External event } \\
\text { Pressurization }\end{array}$ & \begin{tabular}{|l} 
Spread of \\
contaminated water \\
Worker exposure
\end{tabular} & $\begin{array}{l}\text { Tank design } \\
\text { Vent }\end{array}$ & $\begin{array}{l}\text { Procedures and } \\
\text { training }\end{array}$ & $\begin{array}{l}\text { Contents of } \\
\text { tank }\end{array}$ & s3 & $\mathrm{F} 2$ & $\begin{array}{l}\text { The design currently } \\
\text { has no spill } \\
\text { contaiment }\end{array}$ \\
\hline 5.9 & $\begin{array}{l}\text { Excessive } \\
\text { fuel, water, } \\
\text { water vapor } \\
\text { reactions }\end{array}$ & $\begin{array}{l}\text { Air ingress plus } \\
\text { hydrogen buildup } \\
\text { Failure to } \\
\text { completely drain } \\
\text { with delay in } \\
\text { vacuum drying }\end{array}$ & $\begin{array}{l}\text { Hydrogen burning } \\
\text { Fuel ignition }\end{array}$ & $\begin{array}{l}\text { Level indication } \\
\text { on local drain } \\
\text { tank (or similar } \\
\text { measurement) } \\
\text { Draw tube design, } \\
\text { fabricat ion } \\
\text { Gas recirculation } \\
\text { somewhat } \\
\text { redundant to } \\
\text { vacum drying }\end{array}$ & $\begin{array}{l}\text { Procedures and } \\
\text { training } \\
\text { Valve } \\
\text { aligrment } \\
\text { Pressure test } \\
\text { gas fittings }\end{array}$ & One MCO & s3 & F2 & $\begin{array}{l}\text { At this point in the } \\
\text { process, the MCO is } \\
\text { not vented } \\
\text { should evaluate } \\
\text { recovery from fuel } \\
\text { ignition }\end{array}$ \\
\hline $5 . h$ & $\begin{array}{l}\text { Flooding } \\
\text { operator work } \\
\text { area wi th } \\
\text { inert gas }\end{array}$ & $\begin{array}{l}\text { Purge gas line } \\
\text { broken or } \\
\text { leaking }\end{array}$ & $\begin{array}{l}\text { Worker injury or } \\
\text { death }\end{array}$ & $\begin{array}{l}\text { Design to codes } \\
\text { and standards } \\
\text { Buil lding } \\
\text { vent il at ion } \\
\text { systent }\end{array}$ & Procedures & NA & $s 1$ & 83 & $\begin{array}{l}\text { *Argon is heavier } \\
\text { than air, helium is } \\
\text { lighter } \\
\text { For argon, should be } \\
\text { air exchange near } \\
\text { floor }\end{array}$ \\
\hline \multirow[t]{2}{*}{$5 . i$} & \multirow[t]{2}{*}{$\begin{array}{l}\text { Pressurization } \\
\text { of Mco during } \\
\text { purge or vent } \\
\text { cycle }\end{array}$} & \multirow[t]{2}{*}{$\begin{array}{l}\text { Control system } \\
\text { failure } \\
\text { Human error } \\
\text { lnterruption of } \\
\text { cycle with vent } \\
\text { closed }\end{array}$} & $\begin{array}{l}\text { Release of MCO } \\
\text { atmosphere (gases } \\
\text { and particulate) }\end{array}$ & $\begin{array}{l}\text { Rupture disk on } \\
\text { Mcot } \\
\text { Control and } \\
\text { relief system on } \\
\text { purge system } \\
\text { Intertocks }\end{array}$ & $\begin{array}{l}\text { Procedures and } \\
\text { training } \\
\text { Emergency } \\
\text { shutdown } \\
\text { procedure }\end{array}$ & \multirow[t]{2}{*}{$\begin{array}{l}\text { Mco } \\
\text { atmosphere } \\
\text { and } \\
\text { particulate }\end{array}$} & s3 & $F 2$ & \multirow[t]{2}{*}{$\begin{array}{l}\text { Mulsiple failures } \\
\text { required } \\
\text { Limited gas supply } \\
\text { tLinits consequeixess } \\
\text { of pressurization }\end{array}$} \\
\hline & & & $\begin{array}{l}\text { Missile } \\
\text { generation, worker } \\
\text { injury, or damage }\end{array}$ & $\begin{array}{l}\text { Provide for } \\
\text { removal operation }\end{array}$ & $\begin{array}{l}\text { Keep workers } \\
\text { out of area } \\
\text { during purging }\end{array}$ & & s1 & 12 & \\
\hline
\end{tabular}




\begin{tabular}{|c|c|c|c|c|c|c|c|c|c|}
\hline \multirow{2}{*}{\begin{tabular}{|c|}
$\begin{array}{c}\text { Accident/ } \\
\text { system }\end{array}$ \\
\end{tabular}} & \multirow{2}{*}{$\begin{array}{l}\text { Potential } \\
\text { hazard }\end{array}$} & \multirow[b]{2}{*}{ Causes } & \multirow[b]{2}{*}{ Consequerices } & \multicolumn{2}{|c|}{ Safety features } & \multirow{2}{*}{$\begin{array}{c}\text { Inventory at } \\
\text { risk }\end{array}$} & \multirow{2}{*}{\begin{tabular}{|c|}
$\begin{array}{c}\text { Consequence } \\
\text { category }\end{array}$ \\
\end{tabular}} & \multirow{2}{*}{$\begin{array}{l}\text { Frequency } \\
\text { category }\end{array}$} & \multirow[b]{2}{*}{ Renarks } \\
\hline & & & & Engineered & Administrative & & & & \\
\hline \multirow[t]{2}{*}{$5 . j$} & \multirow[t]{2}{*}{$\begin{array}{l}\text { Catastrophic } \\
\text { failure of } \\
\text { vacuun pump }\end{array}$} & \multirow[t]{2}{*}{$\begin{array}{l}\text { Isolation of } \\
\text { vacuum pump } \\
\text { exhaust } \\
\text { Defect in purp }\end{array}$} & $\begin{array}{l}\text { Worker injury from } \\
\text { missiles }\end{array}$ & $\begin{array}{l}\text { Provide for } \\
\text { remote operation } \\
\text { interlocks for } \\
\text { pump protection }\end{array}$ & \multirow[t]{2}{*}{\begin{tabular}{|l|} 
Maintenance \\
Procedures and \\
training \\
Valve lineup \\
checkl ist \\
Keep workers \\
out of area
\end{tabular}} & N/A & s1 & F2 & \\
\hline & & & $\begin{array}{l}\text { Damage to adjacent } \\
\text { equipment } \\
\text { (possible loss of } \\
\text { cooling capacity } \\
\text { to all mCOs) } \\
\end{array}$ & $\begin{array}{l}\text { Interlocks for } \\
\text { pump protection } \\
\text { Missile } \\
\text { protection }\end{array}$ & & \begin{tabular}{|l|} 
Contents of \\
multiple Mcos
\end{tabular} & 53 & 52 & $\begin{array}{l}53 \text { is based on loss } \\
\text { of cool ing } \\
\text { capability }\end{array}$ \\
\hline \multirow[t]{3}{*}{$5 . k$} & \multirow[t]{3}{*}{$\begin{array}{l}\text { Backflow of } \\
\text { vacium pump } \\
\text { oil into mco }\end{array}$} & \multirow[t]{3}{*}{$\begin{array}{l}\text { Purge gas system } \\
\text { fai is } \\
\text { vacuum pump } \\
\text { stops suddenly } \\
\text { Human error } \\
\text { (fail lure to } \\
\text { foll ow } \\
\text { appropriate } \\
\text { shutdown } \\
\text { sequence) }\end{array}$} & $\begin{array}{l}\text { Contamination } \\
\text { coil) in MCO, } \\
\text { failure to meet } \\
\text { product } \\
\text { specifications } \\
\text { Schedule inpact }\end{array}$ & $\begin{array}{l}\text { HEPA-filtered oil } \\
\text { trap } \\
\text { Vacum breaker } \\
\text { Check valve } \\
\text { Use of oil-free } \\
\text { pump }\end{array}$ & \multirow[t]{3}{*}{$\begin{array}{l}\text { Procedures and } \\
\text { training }\end{array}$} & NA & so & 52 & $\begin{array}{l}\text { Consider adding } \\
\text { vacurm breaker } \\
\text { unless amount of oil } \\
\text { is too small to } \\
\text { cause adverse } \\
\text { consequences } \\
\text { downstream } \\
\text { Base design is for } \\
\text { an oil-free pump but } \\
\text { potential exists for } \\
\text { change to oil } \\
\text { lubricated/seal ing } \\
\text { pump }\end{array}$ \\
\hline & & & $\begin{array}{l}\text { MCO pressurization } \\
\text { during staging or } \\
\text { storage because of } \\
\text { increased } \\
\text { radiolyt ic } \\
\text { hydrogen } \\
\text { production } \\
\end{array}$ & & & MCO contents ${ }^{\star}$ & s3 & $\mathrm{F2}$ & $\begin{array}{l}\text { *Based on } \\
\text { pressurization } \\
\text { during storage or } \\
\text { staging }\end{array}$ \\
\hline & & & \begin{tabular}{|l|} 
Change in \\
criticatity \\
configuration (oil \\
as moderator)
\end{tabular} & & & $\begin{array}{l}\text { Mco fissile } \\
\text { inventory }\end{array}$ & so & $F 2$ & $\begin{array}{l}\text { Would require other } \\
\text { failures for } \\
\text { criticality }\end{array}$ \\
\hline 5.1 & $\begin{array}{l}\text { Introduction } \\
\text { of air into } \\
M C D\end{array}$ & $\begin{array}{l}\text { Vecinmm pump } \\
\text { installed } \\
\text { backwards }\end{array}$ & $\begin{array}{l}\text { Pressurizing MCo } \\
\text { Fuel ignition }\end{array}$ & $\begin{array}{l}\text { Suilding } \\
\text { ventilation } \\
\text { MCO rupture disk }\end{array}$ & \begin{tabular}{|l} 
Factory \\
acceptance \\
test; retest \\
requirement \\
after \\
maintenance
\end{tabular} & Mço contents & $\$ 3$ & $? ?$ & $\begin{array}{l}\text { Project should } \\
\text { consider design to } \\
\text { make this very } \\
\text { unl ikely } \\
\text { Mco rupture disk } \\
\text { assumed }\end{array}$ \\
\hline
\end{tabular}


Cold Vacuum Drying System Preliminary Hazard Analysis.

\begin{tabular}{|c|c|c|c|c|c|c|c|c|c|}
\hline \multirow{2}{*}{$\begin{array}{c}\text { Accident/ } \\
\text { system }\end{array}$} & \multirow{2}{*}{$\begin{array}{l}\text { Potential } \\
\text { hazard }\end{array}$} & \multirow{2}{*}{ Causes } & \multirow{2}{*}{ Consequences } & \multicolumn{2}{|c|}{ Safety features } & \multirow{2}{*}{$\begin{array}{c}\text { Inventory at } \\
\text { risk }\end{array}$} & \multirow{2}{*}{$\begin{array}{c}\text { Consequence } \\
\text { category }\end{array}$} & \multirow{2}{*}{\begin{tabular}{|c|}
$\begin{array}{c}\text { Frequency } \\
\text { category }\end{array}$ \\
\end{tabular}} & \multirow{2}{*}{ Remarks } \\
\hline & & & & Engineered & Administrative & & & & \\
\hline $5 . \mathrm{m}$ & $\begin{array}{l}\text { Sucking water } \\
\text { back into Mco } \\
\text { from drain } \\
\text { tank }\end{array}$ & $\begin{array}{l}\text { Yalve } \\
\text { mi salignment }\end{array}$ & $\begin{array}{l}\text { Worst case - high } \\
\text { reaction rate in } \\
\text { MCO } \\
\text { Failure of HEPA } \\
\text { filters because of } \\
\text { wetting } \\
\text { Discharge of dirty } \\
\text { water up the stack } \\
\end{array}$ & \begin{tabular}{|l|} 
No long diptube \\
on local drain \\
tank \\
Level indication \\
in local drain \\
tank \\
Mco reaction rate \\
detection, \\
monitoring \\
Interlocks and \\
control system \\
reliability \\
possible use of \\
metal filters
\end{tabular} & $\begin{array}{l}\text { procedures and } \\
\text { training }\end{array}$ & MCO contents & s3 & F 3 & \\
\hline $5 . n$ & $\begin{array}{l}\text { Sucking water } \\
\text { back into } \\
\text { vacuum pump } \\
\text { from drain } \\
\text { tank }\end{array}$ & $\begin{array}{l}\text { Valve } \\
\text { misal ignment }\end{array}$ & $\begin{array}{l}\text { Failure of KEPA } \\
\text { filters because of } \\
\text { wetting } \\
\text { oischarge of dirty } \\
\text { water up the stack }\end{array}$ & $\begin{array}{l}\text { No long diptube } \\
\text { on drain tank } \\
\text { Level indication } \\
\text { in drain tank } \\
\text { Interlocks and } \\
\text { control system } \\
\text { rel iability } \\
\text { El iminate } \\
\text { connections } \\
\text { between vacum } \\
\text { and local drain } \\
\text { tank }\end{array}$ & & & & & \\
\hline \multirow[t]{2}{*}{5.0} & \multirow[t]{2}{*}{$\begin{array}{l}\text { Overfill of } \\
\text { condenser tank } \\
\text { causing either } \\
\text { of the above }\end{array}$} & \multirow[t]{2}{*}{$\begin{array}{l}\text { Excess water in } \\
\text { the Mco } \\
\text { Condenser or } \\
\text { chiller failure }\end{array}$} & $\begin{array}{l}\text { High reaction rate } \\
\text { in MCO }\end{array}$ & \multirow{2}{*}{$\begin{array}{l}\text { Level indication } \\
\text { in condenser tank } \\
\text { oifferential } \\
\text { pressure across } \\
\text { HEPA fitter } \\
\text { Condenser design } \\
\text { Possitit ise of } \\
\text { metal filters }\end{array}$} & & & & & \\
\hline & & & $\begin{array}{l}\text { Failure of HEPA } \\
\text { filters because of } \\
\text { yetting } \\
\text { Discharge of } \\
\text { condensate up the } \\
\text { stack }\end{array}$ & & & & & & \\
\hline
\end{tabular}




\begin{tabular}{|c|c|c|c|c|c|c|c|c|c|}
\hline \multirow{2}{*}{\begin{tabular}{|c|}
$\begin{array}{c}\text { Accident/ } \\
\text { system }\end{array}$ \\
\end{tabular}} & \multirow{2}{*}{$\begin{array}{c}\text { Potential } \\
\text { hazard }\end{array}$} & \multirow[b]{2}{*}{ Causes } & \multirow[b]{2}{*}{ Consequences } & \multicolumn{2}{|c|}{ Safety features } & \multirow{2}{*}{$\begin{array}{c}\text { Inventory at } \\
\text { risk }\end{array}$} & \multirow{2}{*}{\begin{tabular}{|c|}
$\begin{array}{c}\text { Consequence } \\
\text { category }\end{array}$ \\
\end{tabular}} & \multirow{2}{*}{\begin{tabular}{|c|}
$\begin{array}{c}\text { Frequency } \\
\text { category }\end{array}$ \\
\end{tabular}} & \multirow[b]{2}{*}{ Remarks } \\
\hline & & & & Eng ineered & Administrative & & & & \\
\hline $5 . p$ & $\begin{array}{l}\text { Collapse of } \\
\text { Mco caused by } \\
\text { external } \\
\text { pressure }\end{array}$ & $\begin{array}{l}\text { Vacuum (expected } \\
\text { during this } \\
\text { step) plus } \\
\text { external } \\
\text { pressure from } \\
\text { overheat ing } \\
\text { annular water or } \\
\text { excessive } \\
\text { pressure in } \\
\text { annular water } \\
\text { jacket (dead- } \\
\text { head of } \\
\text { circulation } \\
\text { prnp) } \\
\end{array}$ & $\begin{array}{l}\text { Mco buckl ing } \\
\text { Change in fuel } \\
\text { geometry } \\
\text { Breach of MCO or } \\
\text { cask seal }\end{array}$ & $\begin{array}{l}\text { Vessel designed } \\
\text { for external } \\
\text { pressure* } \\
\text { Pressure relief } \\
\text { on water } \\
\text { circulation } \\
\text { Temperature of } \\
\text { water monitored }\end{array}$ & & & & & \\
\hline \multirow[t]{2}{*}{$\begin{array}{l}5.9 \\
\text { Purge/ } \\
\text { evacuation }\end{array}$} & $\begin{array}{l}\text { Wrong gas } \\
\text { (oxygen, } \\
\text { acetylene, } \\
\text { propane, } \\
\text { xylene, } \mathrm{N}_{2} \mathrm{O} \text { ) } \\
\end{array}$ & \multirow[t]{2}{*}{$\begin{array}{l}\text { Human error } \\
\text { (could be at } \\
\text { vendor) }\end{array}$} & \multirow[t]{2}{*}{\begin{tabular}{|l|} 
Flammability \\
(explosion) \\
Potential reaction \\
With fuel
\end{tabular}} & \multirow[t]{2}{*}{$\begin{array}{l}\text { If gas monitoring } \\
\text { system is } \\
\text { avaitable, the } \\
\text { amount of } \\
\text { reactions would } \\
\text { be limited }\end{array}$} & \multirow[t]{2}{*}{$\begin{array}{l}\text { Vendor qual ity } \\
\text { control } \\
\text { Receiving } \\
\text { inspection of } \\
\text { gas shipment }\end{array}$} & \multirow[t]{2}{*}{ MCO contents } & s3 & $\mathrm{F2}$ & \\
\hline & $\begin{array}{l}\text { Purge gas } \\
\text { mixture off } \\
\text { specification } \\
\text { for } \mathrm{O}_{2} \text { content } \\
\end{array}$ & & & & & & so-s3 & $\mathrm{F3}$ & \\
\hline $5 . r$ & $\begin{array}{l}\text { Contaminated } \\
\text { purge gas } \\
\text { (e.g., oil or } \\
\text { moisture) }\end{array}$ & $\begin{array}{l}\text { Human error } \\
\text { (could be at } \\
\text { vendor) }\end{array}$ & $\begin{array}{l}\text { Oil might make MCO } \\
\text { contents mixed } \\
\text { waste; same } \\
\text { consequence as the } \\
\text { vacum pump } \\
\text { leaking oil into } \\
\text { MCo } \\
\text { Moisture added } \\
\text { after drying, but } \\
\text { probably a limited } \\
\text { amount }\end{array}$ & $\begin{array}{l}\text { Dryer for purge } \\
\text { gas supply }\end{array}$ & $\begin{array}{l}\text { Vendor qual i ty } \\
\text { control, } \\
\text { receiving } \\
\text { inspect ion, } \\
\text { label ing }\end{array}$ & $\begin{array}{l}\text { Mco } \\
\text { atmosphere }\end{array}$ & $\mathrm{so}^{*}$ & $\mathrm{F3}$ & $\begin{array}{l}\text { Additional moistur } \\
\text { in final inerting } \\
\text { might cause problems } \\
\text { in following path } \\
\text { forward activities }\end{array}$ \\
\hline
\end{tabular}




\begin{tabular}{|c|c|c|c|c|c|c|c|c|c|}
\hline \multicolumn{10}{|c|}{ Cold Vacuum Drying $S$} \\
\hline \begin{tabular}{|c|}
$\begin{array}{c}\text { Accident/ } \\
\text { system }\end{array}$ \\
\end{tabular} & $\begin{array}{l}\text { Potential } \\
\text { hazard }\end{array}$ & Causes & Consequences & \multicolumn{2}{|c|}{ Safety features } & $\begin{array}{c}\text { Inventory at } \\
\text { risk }\end{array}$ & $\begin{array}{c}\text { Consequence } \\
\text { category }\end{array}$ & $\begin{array}{l}\begin{array}{l}\text { Frequency } \\
\text { category }\end{array} \\
\end{array}$ & Remarks \\
\hline \begin{tabular}{|l} 
system \\
5.5
\end{tabular} & \begin{tabular}{|l|}
\multicolumn{1}{|c|}{ hazard } \\
A ir ingress \\
through MCO \\
penetration \\
during vacuum \\
drying \\
operation
\end{tabular} & $\begin{array}{l}\text { Broken purge } \\
\text { line } \\
\text { Coupl ing failure } \\
\text { Any penetration } \\
\text { open or failed }\end{array}$ & \begin{tabular}{|l|}
$\begin{array}{l}\text { Fuel-water } \\
\text { vapor-air reaction }\end{array}$ \\
\end{tabular} & 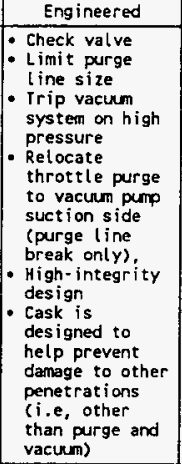 & $\begin{array}{l}\text { Administrative } \\
\text { Limit quantity } \\
\text { of severely } \\
\text { damaged fuel } \\
\text { per mco } \\
\text { (reaction rate } \\
\text { control led) }\end{array}$ & $\frac{\text { risk }}{\text { MCO contents }}$ & \begin{tabular}{|c|} 
category \\
$\$ 3$ \\
\end{tabular} & \begin{tabular}{|c|} 
category \\
$\mathrm{F} 3$
\end{tabular} & \begin{tabular}{|l} 
Based upon \\
eppropriate design \\
features this could \\
be made very \\
infrequent
\end{tabular} \\
\hline $5 . t$ & $\begin{array}{l}\text { Sample vacuum } \\
\text { pump } \\
\text { catastrophic } \\
\text { fai ilure }\end{array}$ & $\begin{array}{l}\text { Various } \\
\text { mechanical } \\
\text { failures }\end{array}$ & $\begin{array}{l}\text { Worker injury from } \\
\text { missiles } \\
\text { Equipment danage }\end{array}$ & & & & & & \\
\hline & & & \begin{tabular}{|l|} 
Damage to adjacent \\
equipment \\
(possible loss of of \\
cool ing capacity) \\
\end{tabular} & & & & & & \\
\hline 5.4 & $\begin{array}{l}\text { High residual } \\
\text { water in MCO }\end{array}$ & \begin{tabular}{|l|} 
Hardware \\
failures \\
Human failure \\
Inadequate \\
characterization \\
of fuel material \\
for inadequats \\
fuel \\
specification \\
Local freezing \\
inadequate \\
dryout of \\
reasonably \\
intact fuel \\
element
\end{tabular} & $\begin{array}{l}\text { Would appear in } \\
\text { fol towing path } \\
\text { forward activities } \\
\text { (shipping, HCA, or } \\
\text { CSB) }\end{array}$ & $\begin{array}{l}\text { Two means of } \\
\text { detect ion }\end{array}$ & & & & & \\
\hline
\end{tabular}




\begin{tabular}{|c|c|c|c|c|c|c|c|c|c|}
\hline \multirow{2}{*}{$\begin{array}{c}\text { Accident/ } \\
\text { system }\end{array}$} & \multirow{2}{*}{$\begin{array}{c}\text { Potential } \\
\text { hazard }\end{array}$} & & & \multicolumn{2}{|c|}{ Safety features } & ard Anaiysi & is. & & \\
\hline & & Causes & Consequences & Engineered & Administrative & $\begin{array}{c}\text { Inventory at } \\
\text { risk }\end{array}$ & $\begin{array}{c}\text { Consequence } \\
\text { categary }\end{array}$ & $\begin{array}{l}\text { Frequency } \\
\text { category }\end{array}$ & Remarks \\
\hline $\begin{array}{l}5 . v \\
\text { Backfill } \\
\text { (see 5.i) }\end{array}$ & $\begin{array}{l}\text { Pressurization } \\
\text { during } \\
\text { backfill }\end{array}$ & & & & & & & & \\
\hline 5.4 & $\begin{array}{l}\text { Failure to } \\
\text { backfill }\end{array}$ & $\begin{array}{l}\text { Human error } \\
\text { Equipment } \\
\text { failure or } \\
\text { incorect valve } \\
\text { lineup }\end{array}$ & \begin{tabular}{|l|} 
Heat ing and \\
hydrogen or other \\
gas generation \\
during shipping \\
Unexpected \\
condition during \\
venting at cSB \\
(e.g., Mco still \\
under vacum) \\
\end{tabular} & $\begin{array}{l}\text { Pressure and flow } \\
\text { indication on } \\
\text { purge line } \\
\text { Computer } \\
\text { supervisory } \\
\text { function }\end{array}$ & & & & & \\
\hline $5 . x$ & $\begin{array}{l}\text { Wrong gas (but } \\
\text { not nitrogen) } \\
\text { (see 5.q) }\end{array}$ & & & & & & & & \\
\hline $\begin{array}{l}5 . y \\
(\text { same as } \\
5 . r)\end{array}$ & $\begin{array}{l}\text { Contaminated } \\
\text { gas }\end{array}$ & & $\begin{array}{l}\text { Moisture added } \\
\text { af ter drying, but } \\
\text { probably a limited } \\
\text { amount }\end{array}$ & & tabel ing & & & & \\
\hline 5.2 & $\begin{array}{l}\text { Backfill with } \\
\text { nitrogen }\end{array}$ & $\begin{array}{l}\text { Valve } \\
\text { misal ignment } \\
\text { Equipnent } \\
\text { failure } \\
\end{array}$ & $\begin{array}{l}\text { Potential reaction } \\
\text { with fuel at } \\
\text { elevated } \\
\text { temperature }\end{array}$ & $\begin{array}{l}\text { Computer } \\
\text { supervisory } \\
\text { funct ion }\end{array}$ & $\begin{array}{l}\text { Valve lineup } \\
\text { checklist }\end{array}$ & MCO contents & $\star$ & $\mathrm{F3}$ & $\begin{array}{l}\text { *Risk will be }_{\text {Rresent at CSB }} \\
\text { prese a }\end{array}$ \\
\hline 5.aa & $\begin{array}{l}\text { Failure to } \\
\text { cool down } \\
\text { before } \\
\text { shipment }\end{array}$ & $\begin{array}{l}\text { Equipment } \\
\text { fai lure } \\
\text { Human error }\end{array}$ & $\begin{array}{l}\text { Shortened shipping } \\
\text { window } \\
\text { MCo } \\
\text { overpressurization } \\
\end{array}$ & $\begin{array}{l}\text { Computer } \\
\text { supervisory } \\
\text { function }\end{array}$ & $\mid$\begin{tabular}{|} 
Procedures and \\
training
\end{tabular} & MCO contents & s3 & $F^{3}$ & $\begin{array}{l}\text { This will al so be a } \\
\text { risk during shipping } \\
\text { and at the cSB } \\
\text { before and during } \\
\text { Mco vent ing } \\
\end{array}$ \\
\hline $\begin{array}{l}\text { 6.a } \\
\text { Post- } \\
\text { processing } \\
\text { activities }\end{array}$ & $\begin{array}{l}\text { Personnel } \\
\text { exposure to } \\
\text { contaminated } \\
\text { piping }\end{array}$ & $\begin{array}{l}\text { Transfer of } \\
\text { contaminated } \\
\text { material (in } \\
\text { contact with } \\
\text { fuel) }\end{array}$ & $\begin{array}{l}\text { Direct radiation } \\
\text { dose to worker } \\
\text { Worker exposure } \\
\text { from airborne } \\
\text { contaminants } \\
\end{array}$ & $\begin{array}{l}\text { Long-handled } \\
\text { tools, cams, and } \\
\text { local radiation } \\
\text { alarm, MCo-cask } \\
\text { design should } \\
\text { consider ALARA }\end{array}$ & $\begin{array}{l}\text { Procedures and } \\
\text { training, } \\
\text { protective } \\
\text { clothing }\end{array}$ & $\begin{array}{l}\text { Residual } \\
\text { contamination } \\
\text { in pipe }\end{array}$ & s1 & $\mathbf{F 3}$ & $\begin{array}{l}\text { Might want to } \\
\text { consider system for } \\
\text { decontaminating } \\
\text { piping }\end{array}$ \\
\hline $6 . b$ & $\begin{array}{l}\text { Personnel } \\
\text { exposure to } \\
\text { pressuri zed } \\
\text { line }\end{array}$ & $\begin{array}{l}\text { Human error (out } \\
\text { of sequence or } \\
\text { procedure) } \\
\text { !ractrertent } \\
\text { activat ion of } \\
\text { purge in } \\
\text { inact ive bay } \\
\text { with worker } \\
\text { present }\end{array}$ & $\begin{array}{l}\text { Worker } \\
\text { contamination (if } \\
\text { contaminated) } \\
\text { workei } \\
\text { asphyxiation (if } \\
\text { inert gas purge } \\
\text { line) } \\
\text { Worker injury from } \\
\text { pipe whip }\end{array}$ & $\begin{array}{l}\text { Design to } \\
\text { minimize problems }\end{array}$ & $\begin{array}{l}\text { Procedures and } \\
\text { training }\end{array}$ & \begin{tabular}{|l|} 
Residual \\
contanination \\
in pipe \\
Pressurized \\
gas
\end{tabular} & 51 & $F 3$ & $\begin{array}{l}\text { If argon is used the } \\
\text { possibility of } \\
\text { leakage into } \\
\text { confined space } \\
\text { should be minimized }\end{array}$ \\
\hline
\end{tabular}


Cold Vacuum Drying System Preliminary Hazard Analysis.

\begin{tabular}{|c|c|c|c|c|c|c|c|c|c|}
\hline \multirow{2}{*}{$\begin{array}{c}\text { Accident/ } \\
\text { system }\end{array}$} & \multirow{2}{*}{$\begin{array}{l}\text { Potential } \\
\text { hazard }\end{array}$} & \multirow{2}{*}{ Causes } & \multirow{2}{*}{ Cons equences } & \multicolumn{2}{|c|}{ Safety features } & \multirow{2}{*}{$\begin{array}{c}\text { Inventory at } \\
\text { risk }\end{array}$} & \multirow{2}{*}{$\begin{array}{c}\text { Consequence } \\
\text { category }\end{array}$} & \multirow{2}{*}{$\begin{array}{c}\text { Frequency } \\
\text { category }\end{array}$} & \multirow{2}{*}{ Remarks } \\
\hline & & & & Engineered & Administrative & & & & \\
\hline $6 . c$ & $\begin{array}{l}\text { orop process } \\
\text { hood (same as } \\
4 . a \text { ) }\end{array}$ & & & & & & & & $\begin{array}{l}\text { At this stage hood } \\
\text { could also be } \\
\text { contaminated }\end{array}$ \\
\hline 6.d & $\begin{array}{l}\text { Pressurized } \\
\text { release from } \\
\text { mCo }\end{array}$ & $\begin{array}{l}\text { oi isconnect } \\
\text { fai lure }\end{array}$ & $\begin{array}{l}\text { Release of } \\
\text { particulate from } \\
\text { MCO }\end{array}$ & $\begin{array}{l}\text { Disconnect design } \\
\text { Process hood }\end{array}$ & \begin{tabular}{|l|} 
Procedures and \\
training \\
Maintenance
\end{tabular} & $\begin{array}{l}\text { MCO } \\
\text { part iculate } \\
\text { release }\end{array}$ & s3 & 83 & \\
\hline $\begin{array}{l}\text { 6.e } \\
\text { Drying } \\
\text { annular } \\
\text { space }\end{array}$ & $\begin{array}{l}\text { See MCo purge } \\
\text { or vent } \\
\text { operat ion } \\
\text { (items } 5 . e \text {, } \\
5 . f, 5 . h \\
\text { through } 5 . j \text {. } \\
5 . n, 5.0,5 . t \text { ) }\end{array}$ & & & & & & & & $\begin{array}{l}\text { Consequences bounded } \\
\text { by mco-vent } \\
\text { operat ion as MCo } \\
\text { water has the } \\
\text { potent ial for a } \\
\text { higher leve! of } \\
\text { contamination than } \\
\text { the MCO annuler } \\
\text { space }\end{array}$ \\
\hline $\begin{array}{l}6 . f \\
\text { Draining of } \\
\text { annulus }\end{array}$ & $\begin{array}{l}\text { Oraining of } \\
\text { annular water } \\
\text { into facility }\end{array}$ & (See 5.e) & & & & & & & \\
\hline $\begin{array}{l}6.9 \\
\text { Draining } \\
\text { annulus }\end{array}$ & $\begin{array}{l}\text { Incomplete } \\
\text { draining of } \\
\text { annulus }\end{array}$ & $\begin{array}{l}\text { Equipment } \\
\text { failure } \\
\text { Human error }\end{array}$ & $\begin{array}{l}\text { Overpressurization } \\
\text { of cask }\end{array}$ & $\begin{array}{l}\text { Level indicating } \\
\text { on local tank } \\
\text { Flow total izer } \\
\text { (may not have } \\
\text { requi red } \\
\text { accuracy) } \\
\text { Moisture monitor } \\
\text { (dew point) on } \\
\text { pumpout line }\end{array}$ & & & & & \\
\hline \begin{tabular}{|l}
$6 . h$ \\
Replace \\
cask lid \\
\end{tabular} & $\begin{array}{l}\text { Drop cask lid } \\
\text { (same as } 3 . \text { a) }\end{array}$ & & & & & & & & \\
\hline $\begin{array}{l}6 . i \\
\text { righten } \\
\text { cask bolts }\end{array}$ & Seal failure & $\begin{array}{l}\text { Bolts not } \\
\text { properly torqued } \\
\text { Bolts fail }\end{array}$ & $\begin{array}{l}\text { Inadequate cask } \\
\text { seal }\end{array}$ & & & & & & \\
\hline $\begin{array}{l}6 . j \\
\text { Purge }\end{array}$ & $\begin{array}{l}\text { Overpressurize } \\
\text { cask }\end{array}$ & $\begin{array}{l}\text { Equipment } \\
\text { failure } \\
\text { Heman error }\end{array}$ & \begin{tabular}{|l} 
Failure of MCO (or \\
MCO rupture disc) \\
Cask failure
\end{tabular} & $\begin{array}{l}\text { Purge gas } \\
\text { Pressure relief } \\
\text { valve tineup } \\
\text { Computer } \\
\text { supervisor } \\
\text { function }\end{array}$ & & & & & . \\
\hline
\end{tabular}




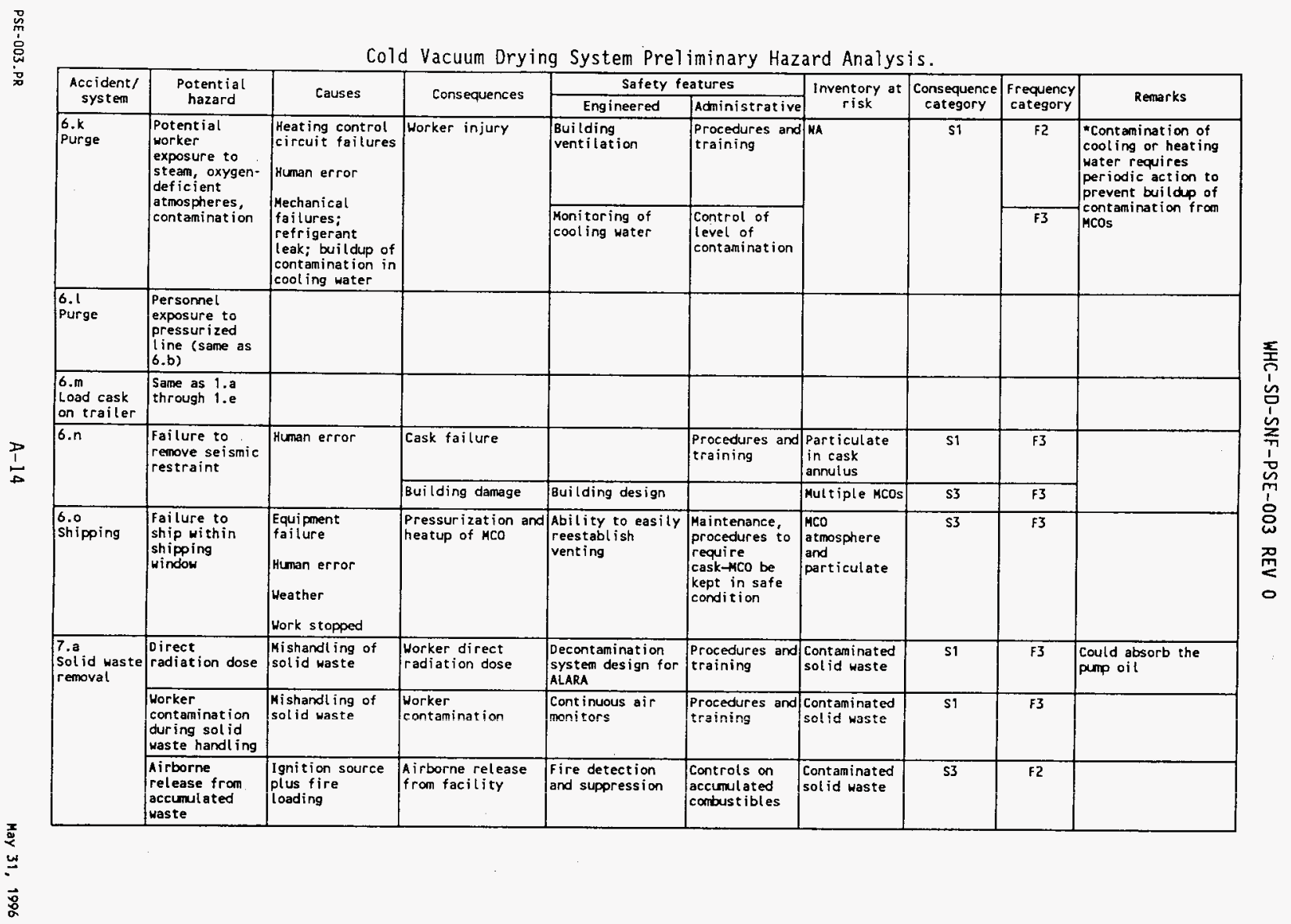


WHC-SD-SNF-PSE-003 REV 0

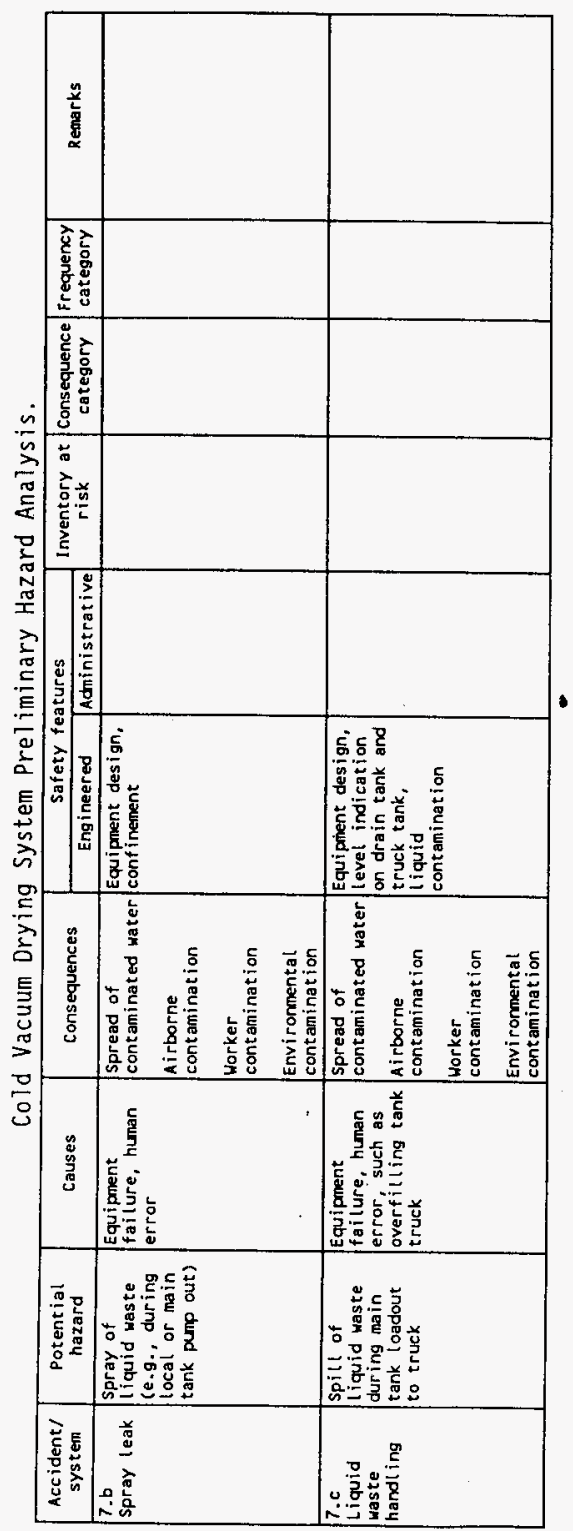


Cold Vacuum Drying System Preliminary Hazard Analysis.

\begin{tabular}{|c|c|c|c|c|c|c|c|c|c|}
\hline \multirow{2}{*}{$\begin{array}{l}\text { Accident/ } \\
\text { system }\end{array}$} & \multirow{2}{*}{$\begin{array}{l}\text { Potential } \\
\text { hazard }\end{array}$} & \multirow{2}{*}{ Causes } & \multirow{2}{*}{ Consequences } & \multicolumn{2}{|c|}{ Safety features } & \multirow{2}{*}{$\begin{array}{c}\text { Inventory at } \\
\text { risk }\end{array}$} & \multirow{2}{*}{$\begin{array}{c}\text { Consequence } \\
\text { category }\end{array}$} & \multirow{2}{*}{$\begin{array}{c}\begin{array}{c}\text { Frequency } \\
\text { category }\end{array} \\
\end{array}$} & \multirow{2}{*}{ Remarks } \\
\hline & & & & Eng ineered & Administrative & & & & \\
\hline $\begin{array}{l}8.0 \\
\text { Natural } \\
\text { phenomena } \\
\text { or human- } \\
\text { induc ed } \\
\text { hazards }\end{array}$ & $\begin{array}{l}\text { Structural } \\
\text { failure of the } \\
\text { cvos facility } \\
\text { and/or sscs } \\
\text { within the } \\
\text { cvos facility }\end{array}$ & $\begin{array}{l}\text { Human-induced } \\
\text { external hazards } \\
\text { and NPH: } \\
\text { Seismic event } \\
\text { Tornado wind } \\
\text { and missiles } \\
\text { High wind } \\
\text { Snow load } \\
\text { Externa! } \\
\text { flooding } \\
\text { (e.g., PMP } \\
\text { runoff) } \\
\text { Light aircraft } \\
\text { impact } \\
\text { Nearby } \\
\text { facilities }\end{array}$ & $\begin{array}{l}\text { In addit ion to the } \\
\text { specific potent } i \text { al } \\
\text { impact of human- } \\
\text { induced external } \\
\text { hazards and NPH } \\
\text { addressed above, } \\
\text { the impact of } \\
\text { major structural } \\
\text { failure of the } \\
\text { cvis facility } \\
\text { and/or SSCs with in } \\
\text { the Cvos facility } \\
\text { needs to be } \\
\text { considered; the } \\
\text { concern is that } \\
\text { the curnulative } \\
\text { effective of one } \\
\text { of the hazards on } \\
\text { the total facility } \\
\text { may be more severe } \\
\text { than has been } \\
\text { ident if ied by the } \\
\text { above evaluation } \\
\text { of risks } \\
\text { associated with } \\
\text { individual cvos } \\
\text { operations. }\end{array}$ & \begin{tabular}{|} 
Building design \\
\\
\end{tabular} & $\begin{array}{l}\text { For some } \\
\text { failures, } \\
\text { mitigating } \\
\text { recovery } \\
\text { actions maybe } \\
\text { effective }\end{array}$ & $\begin{array}{l}\text { Up to } \operatorname{six} \\
\text { MCOs }\end{array}$ & & & $\begin{array}{l}\text { NPH design loadings } \\
\text { for the CVS } \\
\text { facility to be } \\
\text { established } \\
\text { Facility features } \\
\text { not des igned to } \\
\text { withstand the WPH } \\
\text { loadings will need } \\
\text { to be analyzed for } \\
\text { the cumulat ive } \\
\text { effect of their } \\
\text { failures (i.e., the } \\
\text { cumulat ive effect of } \\
\text { taking one hazard } \\
\text { analysis at a time). } \\
\text { NRC standard Review } \\
\text { plan } 3.5 .1 .6^{\circ} \\
\text { provides one } \\
\text { approach for deal ing } \\
\text { with aircraft } \\
\text { hazards. It should } \\
\text { not be assumed that } \\
\text { protection of an Ssc } \\
\text { from the effects of } \\
\text { tornado nissile } \\
\text { impact necessarily } \\
\text { provides protection } \\
\text { against the impact } \\
\text { of light aircraft. }\end{array}$ \\
\hline
\end{tabular}

ICBO, 1991, Uniform Building Code, International Conference of Building officials, whittier, California.

of light aireraft

ALARA = as low as reasonable ach ievable.

CSB = Canister storage Building.

CVDS = Cold Vacum Drying system

$H C A=$ Hot Conditioning Annex.

HEPA = high-efficiency particulate air (filter).

HVAC = heating, ventillating, and air conditicning.

LFL = lower flamability limit.

$\mathrm{MCO}=\mathrm{mult}$ icanister overpack

NA $=$ not appl icable.

UPH = natural phenomena hazard.

Pur = probable maximini pitétipitation.

SSC = structure, system and component. 


\section{HEDOP REVIEW CHECKLIST}

for

\section{Radiological and Nonradiological Release Calculations}

Document reviewed (include tit)e or description of calculation, document number, author, and date, as applicable):

Preliminary Safety Evaluation for the Cold Vacuum Orying system, WHC-SD-SNF-PSE-003, 5/3/96 DRAFT

Submitted by: Dan Reny

Date Submitted: $5 / 10 / 96$

Scope of Review: Accident Evaluation Sections 4.0-4.5

YES NO* N/A

A. [ ] [ ] 1. A detailed technical review and approval of the environmental transport and dose calculation portion of the analysis has been performed and documented.

54 [ ] [ ] 2. Detailed technical review(s) and approval(s) of scenario and release determinations have been performed and documented.

[ ] [ ] $\triangle$ 3. HEDOP-approved code(s) were used.

[ ] [ ] Bd 4. Receptor locations were selected according to HEDOP recommendations.

4. [ ] [ ] 5. All applicable environmental pathways and code options were included and are appropriate for the calculations.

D4 [ ] [ ] 6. Hanford site data were used.

4. [ ] [ ] 8. The analysis is consistent with HEDOP recommendations.

[] 9. Supporting notes, calculations, comments, comment resolutions, or other information is attached. (Use the "Page 1 of $X$ " page numbering format and sign and date each added page.)

1) [ ]

10. Approval is granted on behalf of the Hanford Environmental Dose Overview Panel.

* A11 "NO" responses must be explained and use of nonstandard methods justified.

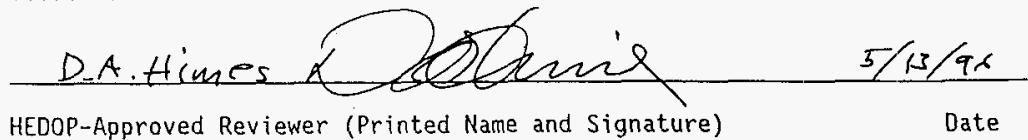

COMMENTS (add additional signed and dated pages if necessary): 


\section{CHECKLIST FOR PEER REVIEW}

Document Reviewed: Preliminary Safety Evaluation for the Cold Vacuum Drying system, Accident Analys is Section 4.2, WHC-SD-SNF-PSE-003, 5/3/96 DRAFT

Scope of Review: Section 4.2 on ly

$\frac{\text { Yes } N o \text { NA }}{[][] \text { * }}$ *

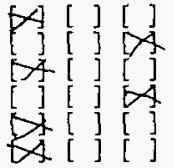

$\Delta[][]$

LA [ ] [ ]

[X] [ ] [ ]

[\}$][][X$

[ ] [ ] [4

Previous reviews complete and cover analysis, up to scope of this review, with no gaps.

Problem completely defined.

Accident scenarios developed in a clear and logical manner. Necessary assumptions explicitly stated and supported.

Computer codes and data files documented.

Data used in calculations explicitly stated in document.

Data checked for consistency with original source information as applicable.

Mathematical derivations checked inciuding dimensional consistency of results.

Models appropriate and used within range of validity or use outside range of established validity justified.

Hand calculations checked for errors. Spreadsheet results should be treated exactly the same as hand calculations.

Software input correct and consistent with document reviewed. Software output consistent with input and with results reported in document reviewed.

Limits/criteria/guidelines applied to analysis results are appropriate and referenced. Limits/criteria/guidelines checked against references.

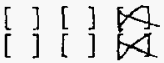

Safety margins consistent with good engineering practices. Conclusions consistent with analytical results and applicable limits.

[ ] [ ] [A] Results and conclusions address all points required in the problem statement.

[ ] [ ] DA Format consistent with appropriate NRC Regulatory Guide or other standards

[ ] [X] Review calculations, comments, and/or notes are attached.

$\Delta[$ ] [ ]

Document approyed.

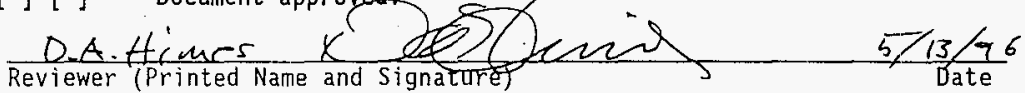

* Any calculations, comments, or notes generated as part of this review should be signed, dated and attached to this checklist. Such material should be labeled and recorded in such a manner as to be intelligible to a technically qualified third party. 


\section{PEER REVIEW CHECKLIST}

Document Reviewed: Preliminary Safety Evaluation for the Cold Vacuum Drying System, Accident Analys is Section 4.3.2, Flammable Gas

Author: David L. Scott

Date: May 3, 1996

Scope of Review: Section 4.3.2, Flammalle Gas

$\frac{\text { Yes No NA }}{[x][-[1}$

$\left.\begin{array}{lll}{[x]} & {[} & {[} \\ {[x]} & {[} & {[} \\ {[x]} & {[} & {[} \\ {[]} & {[} & {[} \\ {[x]} & {[} & {[} \\ {[x]} & {[} & {[}\end{array}\right]$

(x) [ ] [ ]

[X] [ ] [ ]

X] [ ] [ ]

$\left[\begin{array}{lll}{[} & {[}\end{array}\right]\left[\begin{array}{ll}{[x]} \\ {[}\end{array}\right]$

X] [ ] [ ]

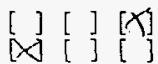

$[X][][]$

$x[3[]$

$[\varnothing[][]$

$\mathbb{X}[]][]$
Previous reviews complete and cover analysis, up to scope of this review, with no gaps.

Problem completely defined.

Accident scenarios developed in a clear and logical manner. Necessary assumptions explicitly stated and supported.

Computer codes and data files documented.

Data used in calculations explicitly stated in document.

Data checked for consistency with original source information as applicable.

Mathematical derivations checked including dimensional consistency of results.

Models appropriate and used within range of validity or use outside range of established validity justified.

Hand calculations checked for errors. Spreadsheet results should be treated exactly the same as hand calculations.

Software input correct and consistent with document reviewed. Software output consistent with input and with results reported in document reviewed.

Limits/criteria/guidelines applied to analysis results are appropriate and referenced. Limits/criteria/guidelines checked against references.

Safety margins consistent with good engineering practices. Conclusions consistent with analytical results and applicable limits.

Results and conclusions address all points required in the problem statement.

Format consistent with appropriate NRC Regulatory Guide or other standards

Review calculations, comments, and/or notes are attached.

Document approved

RAcph Crowr

Reviewer (Printed Name and Signature)
$\operatorname{May} 10, \frac{1996}{\text { Date }}$ 


\section{PEER REVIEW CHECKLIST}

Document Reviewed: Preliminary Safety Evaluation for the Spent Nuclear Fuel Projects Cold Vacuum Drying System, Accident Anaiys is

Author: Dan Reny

Date: $5 / 10 / 96$

Scope of Review: Secition 4.3,3, MCO Overpiessurizator

$\frac{\text { Yes No NA }}{[][][X]}$

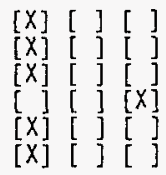

$[\mathrm{X}][\mathrm{l}][\mathrm{s}$

[][]$[x]$

$[\mathrm{X}][\mathrm{]}] \mathrm{B}$

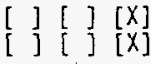

$[x][][]$

$[x]\left[\begin{array}{l}{[} \\ {[x]}\end{array}\right]$

$[x][][]$

[X] [ ] [ ]

[X] [ ] [ ]

[ ] [X] [ ] Review calculations, comments, and/or notes are attached.

[X] [ ] [ ] Document approved.

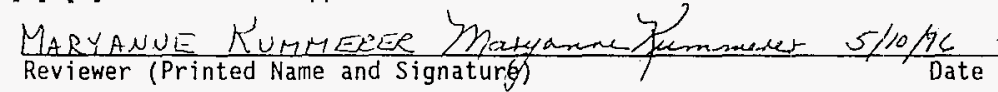

Previous reviews complete and cover analysis, up to scope of this review, with no gaps.

Problem completely defined.

Accident scenarios developed in a clear and logical manner.

Necessary assumptions explicitly stated and supported.

Computer codes and data files documented.

Data used in calculations explicitly stated in docuinent.

Data checked for consistency with original source information as applicable.

Mathematical derivations checked including dimensional consistency of results.

Models appropriate and used within range of validity or use outside range of established validity justified.

Hand calculations checked for errors. Spreadsheet results should be treated exactly the same as hand calculations.

Software input correct and consistent with document reviewed.

Software output consistent with input and with results reported in document reviewed.

Limits/criteria/guidelines applied to analysis results are appropriate and referenced. Limits/criteria/guidelines checked against references.

Safety margins consistent with good engineering practices.

Conclusions consistent with analytical results and applicable limits.

Results and conclusions address all points required in the problem statement.

Format consistent with appropriate NRC Regulatory Guide or other standards 


\section{PEER REVIEW CHECKLIST}

Document Reviewed: Preliminary Safety Evaluation for the Spent Nuclear Fuel Projects Cold Vacuum Drying System, Accident Analysis

Author: Dan Reny

Date: $5 / 10 / 96$

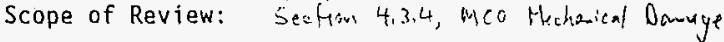

Yes No $N A$

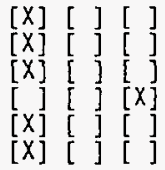

[X] [ ] [ ]

[ ] [ ] $[\mathrm{X}]$

$[X][][]$

$\left[\begin{array}{lll}] & {[}\end{array}\right]\left[\begin{array}{l}x \\ {[}\end{array}\right]$

[X] [ ] [ ]

$[x][][]$

$[x][][]$

$[X][][]$

[X] [ ] [ ]

[ ] $[X][$ ]
Previous reviews complete and cover analysis, up to scope of this review, with no gaps.

Problem completely defined.

Accident scenarios developed in a clear and logical manner.

Necessary assumptions explicitly stated and supported.

Computer codes and data files documented.

Data used in calculations explicitly stated in document.

Data checked for consistency with original source information as applicable.

Mathematical derivations checked including dimensional consistency of results.

Models appropriate and used within range of validity or use outside range of established validity justified.

Hand calculations checked for errors. Spreadsheet results should be treated exactly the same as hand calculations.

Software input correct and consistent with document reviewed. Software output consistent with input and with results reported in document reviewed.

Limits/criteria/guidelines applied to analysis results are appropriate and referenced. Limits/criteria/guidelines checked against references.

Safety margins consistent with good engineering practices.

Conclusions consistent with analytical results and applicable limits.

Results and conclusions address all points required in the problem statement.

Format consistent with appropriate NRC Regulatory Guide or other standards

Review calculations, comments, and/or notes are attached.

[X] [ ] [ ] Document approved.

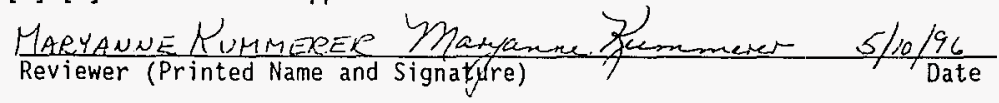




\section{PEER REVIEW CHECKLIST}

Document Reviewed: Preliminary Safety Evaluation for the Spent Nuclear Fuel Projects Cold Vacuum Drying System, Accident Anllysis

Author: Dan Reny

Date: $5 / 10 / 96$

Scope of Review: Section 4,3,5, Fud Iynition

Yes No NA

[ ] [ ] [X]

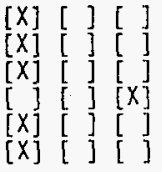

[X] [ ] [ ]

[ ] [ ] $[\mathrm{X}]$

[X] [ ] [ ]

[\}[\}$][X]$

[X] [ ] [ ]

$\left.\begin{array}{llll}{[X]} & {[}\end{array}\right]\left[\begin{array}{l}{[} \\ X]\end{array}\right][][]$

[X] [ ] [ ]

[X] [ ] [ ]

[ ] [X] [ ]

[X] [ ] [ ] Document approved. as applicable. limits. problem statement. other standards
Previous reviews complete and cover analysis, up to scope of this review, with no gaps.

Problem completely defined.

Accident scenarios developed in a clear and logical manner.

Necessary assumptions exp1icitly stated and supported.

Computer codes and data files documented.

Data used in calculations explicitly stated in document.

Data checked for consistency with original source information

Mathematical derivations checked including dimensional consistency of results.

Models appropriate and used within range of validity or use outside range of established validity justified.

Hand calculations checked for errors. Spreadsheet results should be treated exactly the same as hand calculations.

Software input correct and consistent with document reviewed.

Software output consistent with input and with result:s reported in document reviewed.

Limits/criteria/guidelines applied to analysis results are appropriate and referenced. Limits/criteria/guidelines checked against references.

Safety margins consistent with good engineering practices. Conclusions consistent with analytical results and applicable

Results and conclusions address all points required in the

Format consistent with appropriate NRC Regulatory Guide or

Review calculations, coments, and/or notes are attached.

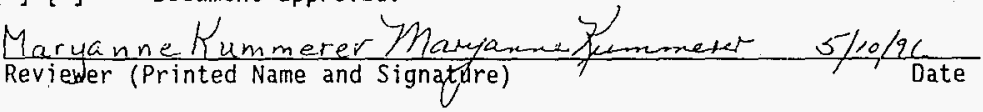




\section{PEER REVIEW CHECKLIST}

Document Reviewed: Preliminary Safety Evaluation for the Spent Nuclear Fue Projects Cold Vacuum Drying System, Accident Analysis Section 4.3.6, Liquid Releases, WHC-SD-SNF-PSE-003, DRAFT

Author: Steve Kopelic

Date: $5 / 8 / 96$

Scope of Review: Accident Analysis Section 4.3.6, Liquid Releases

$\frac{\text { Yes No NA }}{[][][X]}$

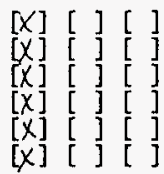

$M][$ ] [ ]

[X] [ ] [ ]

[X] [ ] [ ]

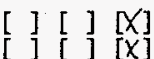

V][ ] [ ]

$[x][][]$

$[X][][]$

[X] [ ] [ ]

$[X][][]$

$[x][][]$

X] [ ] [ ] Document approved.

$\frac{\text { D. L. Scott Dace Scott }}{\text { Reviewer (Printed Name and Signature) }} 5 / 10 / 46$

Previous reviews complete and cover analysis, up to scope of this review, with no gaps.

Problem completely defined.

Accident scenarios developed in a clear and logical manner. Necessary assumptions explicitly stated and supported. Computer codes and data files documented.

Data used in calculations explicitly stated in document. Data checked for consistency with original source information as applicable.

Mathematical derivations checked including dimensional consistency of results.

Models appropriate and used within range of validity or use outside range of established validity justified.

Hand calculations checked for errors. Spreadsheet results should be treated exactly the same as hand calculations. Software input correct and consistent with document reviewed. Software output consistent with input and with results reported in document reviewed.

Limits/criteria/guidelines applied to analysis results are appropriate and referenced. Limits/criteria/guidelines checked against references.

Safety margins consistent with good engineering practices. Conclusions consistent with analytical results and applicable limits.

Results and conclusions address all points required in the problem statement.

Format consistent with appropriate NRC Regulatory Guide or other standards

Review calculations, comments, and/or notes are attached.

Reviewer (Printed Name and Signature) 
WHC-SD-SNF-PSE-003 REV 0

This page intentionally left biank. 